\title{
CARBONO ORGÂNICO DISSOLVIDO NA SOLUÇÃO DO SOLO SOB FLORESTA E PASTAGEM EM RONDÔNIA
}

\author{
MARCELO ELIAS CASSIOLATO \\ Engenheiro Agrônomo \\ Orientador: Prof. Dr. CARLOS CLEMENTE CERRI
}

Dissertação apresentada à Escola Superior de Agricultura "Luiz de Queiroz", Universidade de São Paulo, para obtenção do título de Mestre em Agronomia, Área de Concentração: Solos e Nutrição de Plantas.

PIRACICABA

Estado de São Paulo - Brasil

Dezembro - 2002 
MARCELO ELIAS CASSIOLATO. Carbono orgânico dissolvido na solução do solo sob floresta e pastagem em Rondônia

p. ítem linha onde se lê leia-se

$92.3 \quad$ Figura 1 lu ioli i ia o; $\quad$ Pluviolixiviado; iteira;

i i ia 0 ;

iac o

Liteira;

Lixviação;

Riacho

474.6 oitava …apresentou uma compactação que a pastagem...

....apresentou uma compactação menor que a pastagem...

$49 \quad 4.6 .1$ nona $\quad$... já que sta se encontra em equilíbrio...

... já que esta se encontra em equilíbrio...

$\begin{array}{llll}50 & 4.6 .2 & \text { décima ...na solução do solo }\end{array}$ também foi que a concentração...

...na solução do solo também foi menor que a concentração...

$51 \quad 4.6 .3$ décima ...que a pastagem ...que a pastagem primeira controle possui...em relação a pastagem controle.... gradeada possui...em relação a pastagem controle... 


\section{Dados Internacionais de Catalogação na Publicação (CIP)}

DIVISÃO DE BIBLIOTECA E DOCUMENTACCÃO - ESALQ/USP

\section{Casslolato, Marcelo Elias}

Carbono organico dissolvido na soluçăo do solo sob floresta e pastagem em Rondônia / Marcelo Elias Cassiolato. - - Piracicaba, 2002.

$70 \mathrm{p}$.

Dissertaçăo (mestrado) -. Escola Superior de Agricultura Luiz de Queiroz, 2002. Bibliografia.

1. Carbono organico 2. Escoamento 3. Llxivlaçăo do solo 4. Pastagem 5. Solo fiorestal 6. Soluçăo do solo 7. Sucessão florestal I. Titulo

CDD 634.9 
A Deus e a Nossa Senhora Aparecida

Humildemente ofereço.

Aos meus pais, José Carlos e Carmem

A Minha irmãzinha Márcia

E a meu grande amor, Heloísa

Dedico 


\section{AGRADECIMENTOS}

Ao Prof. Dr. Carlos Clemente Cerri, pelo acolhimento, valiosa orientação e bons momentos.

Ao Dr. Eric Roose (ORSTOM/Montpellier-França) pelos inestimáveis conhecimentos, sugestões e apoio.

A pesquisadora do CENA/USP, Marisa de Cássia Piccolo, pelo grande esforço na execução dessa pesquisa.

Aos pesquisadores do Ecosystem Center (Woods Hole/USA) Jerry Mellilo e Christopher Neill, pelas sugestões e colaborações.

A Prof. Dra. Sonia Maria Stefano Piedade e a pós-graduanda Melissa Oda, pelo auxílio nas analises estatísticas.

Aos meus "irmãos" Flávio e Ademir pelo inestimável auxílio nos mais delicados momentos durante o período do mestrado.

Aos grandes amigos que fiz: Karine, Marquinhos, Dina, Cris, Gabor, Solismar, Caio, Cristiano, Janaína, João de Deus, Ariana, Jorge, Juliano, Simão pelo apoio e amizade.

Aos técnicos Gilmar e Newton (Emater - RO) pela amizade e importante colaboração na execução das atividades de campo.

As secretárias Mara e Nancy pela gentileza e atenção constante. 
A técnica de laboratório e amiga Lílian, pela ajuda nas análises laboratoriais.

Aos pesquisadores, Maria Cristina Forti (Inpe) e Alex Krusche (CENA/USP), pelos esclarecimentos e sugestões.

Ao Sr. João Arantes Júnior, proprietário da Fazenda Nova Vida (Rondônia) pelas facilidades oferecidas.

A coordenação do curso de Pós-graduação em Solos e Nutrição de Plantas da ESALQ/USP pela oportunidade concedida.

A CAPES pela concessão de bolsa no biênio 2001/02.

À FAPESP pelo apoio financeiro ao (Projeto de pesquisa 00/08239-2).

À DOW AGRO SCIENCE pelo apoio tecnológico.

Finalmente, a todos aqueles que direta ou indiretamente colaboraram para realização deste trabalho. 


\section{SUMÁRIO}

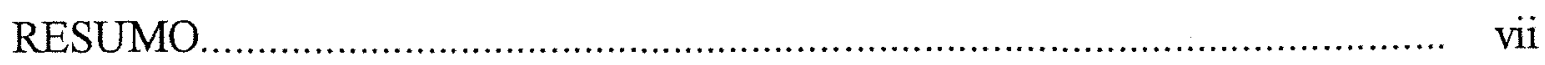

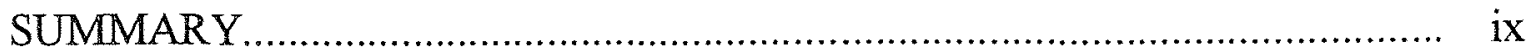

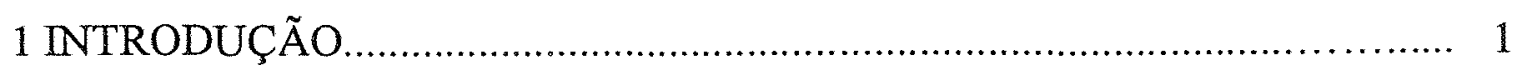

2 REVISÃO DE LITERATURA................................................................ 3

2.1 Características gerais sobre a região Amazônica............................................ 3

2.2 Mudança das características do solo pela sucessão floresta/pastagem........... 5

$2.3 \mathrm{O}$ carbono nos ecossistemas da região Amazônica.......................................... 6

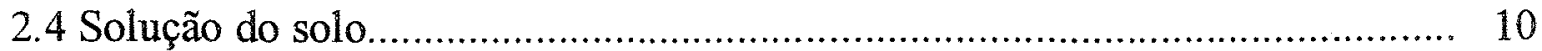

2.5 Carbono orgânico dissolvido..................................................................... 13

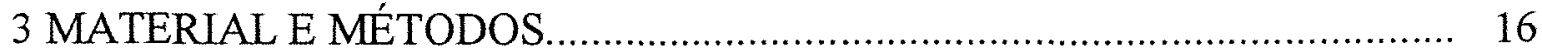

3.1 Localização geográfica e características climáticas da região....................... 16

3.2 Descrição da área experimental.............................................................. 19

3.3 Coleta das Amostras............................................................................... 24

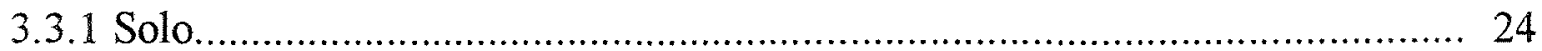

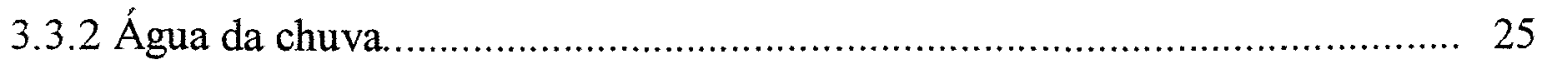

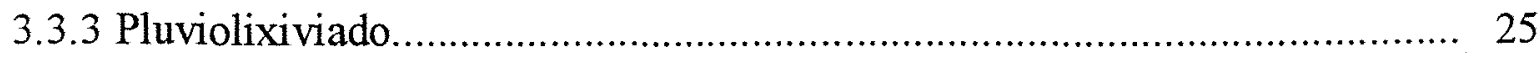

3.3.4 Disposição dos coletores das soluções do solo............................................. 26

3.3.4.1 Escoamento superficial......................................................................... 28

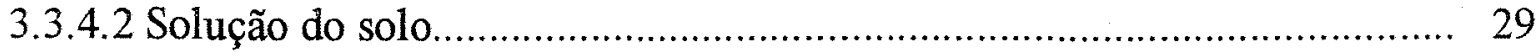

3.3.4.3 Solução lixiviada do solo................................................................... 30

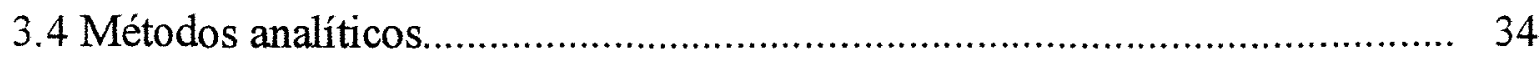


3.4.1 Caracterização química do solo............................................................. 34

3.4.2 Caracterização química das soluções......................................................... 35

3.4.2.1 pH e condutividade elétrica............................................................. 35

3.4.2.2 Força Iônica.............................................................................. 36

3.4.2.3 Carbono orgânico dissolvido ................................................................ 36.

3.5 Analise estatística dos resultados............................................................ 37

4 RESULTADOS E DISCUSSÕES.............................................................. 38

4.1 Características da água da chuva............................................................. 38

4.2 Características do pluviolixiviado............................................................ 40

4.3 Composição química da solução de escoamento superficial......................... 42

4.4 Composição química da solução do solo .................................................... 44

4.5 Composição química da solução lixiviada.................................................... 45

4.6 Estoque do carbono orgânico e pH do solo.................................................. 47

4.7 Estimativa do fluxo de carbono dissolvido no solo.................................... 48

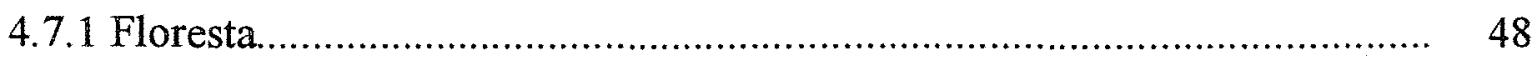

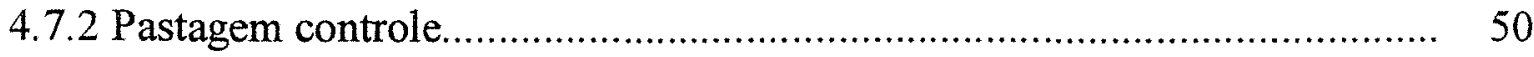

4.7.3 Pastagem gradeada ....................................................................... 51

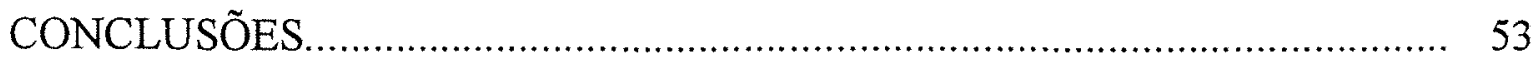

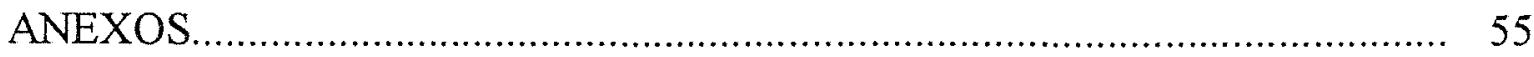

REFERÊNCIAS BIBLIOGRÁFICAS .................................................... 59 


\title{
CARBONO ORGÂNICO DISSOLVIDO NA SOLUÇÃO DO SOLO SOB FLORESTA E PASTAGEM EM RONDÔNIA
}

\author{
Autor: MARCELO ELIAS CASSIOLATO \\ Orientador: Prof. Dr. CARLOS CLEMENTE CERRI
}

\section{RESUMO}

A pesquisa teve por objetivo avaliar o fluxo do carbono orgânico dissolvido na solução do solo sob floresta e pastagens da região Amazônica. $O$ experimento constou da instalação de lisímetros de tensão, tensão zero, e coletores de escoamento superficial, pluviolixiviado e água de chuva em condições de campo durante o período de janeiro a maio de 2002 na fazenda Nova Vida, município de Ariquemes no estado de Rondônia. Foi quantificada a concentração de carbono orgânico dissolvido, o pH e a condutividade elétrica em três tratamentos: i) floresta nativa; ii) pastagem (controle) com 20 anos de uso; iii) pastagem de Brachiaria brizantha porém gradeada, fertilizada e replantada. A análise química da água da chuva mostrou uma concentração de carbono orgânico dissolvido elevada, em torno de $4 \mathrm{mg} \mathrm{L}^{-1}$, que adicionou aos tratamentos aproximadamente $3000 \mathrm{mg} \mathrm{de} \mathrm{C} \mathrm{m}^{-2}$. Os pluviolixiviados apresentaram um teor de carbono orgânico dissolvido ainda mais elevado e acrescentaram ao solo cerca de $5200 \mathrm{mg}$ de $\mathrm{C} \mathrm{m}^{-2}$. A solução de escoamento superficial foi entre as formas analisadas a que apresentou a maior movimentação do carbono orgânico dissolvido. Sob floresta, essa solução apresentou as maiores concentrações de carbono orgânico dissolvido, porém com o menor volume de solução coletada. Sendo assim, o tratamento 
controle foi o que apresentou as maiores perdas de carbono (1680 $\mathrm{mg} \mathrm{de} \mathrm{C} \mathrm{m}^{-2}$ ) por escorrimento superficial, enquanto $o$ tratamento floresta perdeu menos (173 de $\mathrm{C} \mathrm{mg} \mathrm{m} \mathrm{m}^{-2}$ ) por essa via. As concentrações de carbono orgânico dissolvidas na solução lixiviada foram pequenas, 7, 85 e $106 \mathrm{mg}$ de $\mathrm{C} \mathrm{m}^{-2}$ para floresta, controle e pastagem gradeada respectivamente. A concentração de carbono orgânico dissolvido na solução do solo foi de 4,87, 4,09 e 3,63 $\mathrm{mg} \mathrm{L}^{-1}$ para pastagem gradeada, floresta e controle. Estes resultados foram obtidos no primeiro período de chuvas após a instalação dos equipamentos no campo. Interpretações mais abrangentes só serão possíveis após estudos a longo prazo, que contemplem diversos períodos de coleta que levem em conta oscilações naturais da pluviosidade. 


\title{
DISSOLVED ORGANIC CARBON IN SOIL SOLUTION UNDER FOREST AND PASTURE IN RONDÔNIA
}

\author{
Author: MARCELO ELIAS CASSIOLATO \\ Adviser: Prof. Dr. CARLOS CLEMENTE CERRI
}

\section{SUMMARY}

This study aimed to quantify the flow of organic carbon dissolved in soil solution collected under forest and pastures of Amazonian region. The experiment consisted of the installation of several tension lysimeters, free tension lysimeters, and runoff, throughfall and rainfall collectors in field conditions during the period of January to May 2002 at Nova Vida ranch, located in the district of Ariquemes, Rondônia state. Dissolved organic carbon concentration , $\mathrm{pH}$ and electric conductivity were quantified in three treatments: i) native forest; ii) 20 years-old pasture (control); iii) recently plowed, fertilized and newly replanted Brachiaria brizantha (plowed pasture). Chemical analysis of the rain water showed a high concentration of dissolved organic carbon $\left(4 \mathrm{mg} \mathrm{L}^{-1}\right.$ ), providing an input of approximately $3000 \mathrm{mg} \mathrm{C} \mathrm{m}^{-2}$ to the soil. The amount in throughfall was even higher and added approximately $5200 \mathrm{mg} \mathrm{C}$ $\mathrm{m}^{-2}$ to the soil. The runoff presented the largest movement of dissolved organic carbon. Solution collected from soil under forest showed the highest concentrations of dissolved organic carbon, although in the smallest volume. So far, the control treatment presented the largest losses of carbon $\left(1680 \mathrm{mg} \mathrm{C} \mathrm{m}^{-2}\right)$ by runoff while the forest had the smallest (173 $\left.\mathrm{mg} \quad \mathrm{C} \mathrm{m}^{-2}\right)$. Dissolved organic carbon amount in 
the leached solution were small, 7, 85 and $106 \mathrm{mg} \mathrm{C} \mathrm{m}^{-2}$ under forest, control and plowed pasture respectively. Dissolved organic carbon concentration in the soil solution was $4,87,4,09$ and $3,63 \mathrm{mg} \mathrm{L}^{-1}$ in the plowed pasture, forest and control. However, these results were obtained during the initial period after installation of the equipments and therefore, more conclusive results will only be possible throughout time, mainly related to changes in rainfall regime. 


\section{INTRODUÇÃO}

A discussão em torno da possibilidade da Amazônia influenciar as mudanças climáticas globais tem sido muito discutida atualmente. Normalmente as mudanças climáticas estão relacionadas ao efeito estufa, causado pelo aumento de gases como o $\mathrm{CO}_{2}$ na atmosfera. Embora já se conheça a maior parte do ciclo do carbono na região amazônica, ainda existem muitas dúvidas sobre seu completo funcionamento. Alguns autores afirmam que a Amazônia funciona como um absorvedouro do carbono atmosférico enquanto outros combatem esta afirmação com dados que mostram que Amazônia pode ser uma fonte de carbono para a atmosfera.

A Região Amazônica contém uma quantidade enorme de ecossistemas e grande riqueza em termos de diversidade biológica e étnica, sua extensão de floresta tropical é de mais 4,5 milhões de $\mathrm{km}^{2}$ apenas no território Brasileiro, respondendo por um quarto das espécies animais e vegetais do planeta. Nesse contexto se percebe a necessidade de maiores estudos em uma região tão extensa e que gera tantas dúvidas sobre seu ecossistema.

Os desmatamentos, as queimadas e as mudanças no uso da terra na região tem gerado ainda mais dúvidas sobre os efeitos climáticos e sobre a possíbiliade de sustentabilidade de outro tipo de atividade agrícolas na região. A atividade pecuária tem sido, desde 1960, o principal uso econômico da terra na região. Com a queima, grandes quantidades de nutrientes são incorporadas ao solo via cinzas, aumentando a sua fertilidade, tornando as pastagens produtivas nos primeiros anos de implantação. Contudo, após cerca de cinco a oito anos de uso, tem-se observado um declínio gradual da produtividade e do valor nutritivo dos pastos, coincidindo com processo de degradação. 
Atualmente acredita-se que a matéria orgânica seja a chave para o sucesso de diferentes tipos de uso da terra na região, sendo que seu manejo adequado pode até contribuir para o seqüestro de carbono da atmosfera. Porém, para isso a o conhecimento da participação da matéria orgânica em todo o processo e de vital importância. A baixa fertilidade dos solos na região Amazônica torna a matéria orgânica a principal fonte de nutrientes para as plantas, tornando o ciclo do carbono a principal fonte de sustentabilidade do ecossistema natural ou manejado na Amazônia.

O grande problema é que nessa região a maioria dos estudos que envolvem o ciclo do carbono estão ligadas a matéria orgânica sólida do solo, as águas dos rios e ao fluxo de gases, e geralmente não envolvem uma das partes mais importantes que é o elo de ligação entre a atmosfera, o solo e os rios e oceanos, que é a forma dissolvida do carbono no solo.

Estudos sobre a solução do solo e principalmente sobre o carbono orgânico dissolvido nos solos tropicais são muito raros, o que dificultam o completo entendimento do ciclo do carbono na Amazônia. O reconhecimento da importância da solução do solo nos estudos sobre a química e a qualidade do solo, já existe à vários anos. Vários autores têm dando ênfase à fase líquida dos sistemas agropecuários e investigando os processos que nela ocorrem como resultado da ação dos agentes biológicos, hidrológicos e geológicos e sua forma mais adequada de extração.

Entretanto, o estudo da solução do solo e de outros processos que compõem a hidrologia da região, como a lixiviação e o escoamento superficial, não são simples e exigem vários cuidados para evitar a obtenção de informações que realmente expressem as concentrações e participações do carbono orgânico dissolvido na ciclagem dos nutrientes dos sistemas naturais ou manejados.

De acordo com estas informações, o objetivo central do trabalho foi estudar o carbono orgânico dissolvido presente na chuva, na solução pluviolixiviada de uma floresta natural e nas soluções de escoamento superficial, do solo e da solução lixiviada sob floresta e pastagem no estado de Rondônia. 


\section{REVISÃO DE LITERATURA}

\subsection{Características gerais sobre a região Amazônica}

A Região Amazônica contém uma gama variada de ecossistemas e grande riqueza em termos de diversidade biológica e étnica. Incluí a maior extensão de floresta tropical da Terra, mais de 5 milhões de $\mathrm{km}^{2}$, sendo 4,5 milhões de $\mathrm{km}^{2}$ no território Brasileiro, respondendo por um quarto da espécies animais e vegetais do planeta.

A região armazena mais de cem gigatoneladas de carbono em vegetação e solos. Mas, durante os últimos anos o desenvolvimento rápido levou ao desflorestamento de mais de 550 mil $\mathrm{km}^{2}$ só no Brasil. As taxas de desflorestamento anual no território Brasileiro estão entre 15 a $20 \mathrm{mil} \mathrm{km}^{2}$, segundo os números do Instituto Nacional de Pesquisas Espaciais - INPE (2001), baseado em análises do satélite Landsat. Somente em Rondônia, a área desmatada até o ano de 1996 foi estimada em $48.800 \mathrm{~km}^{2}$ (INPE, 1998), correspondendo à cerca de $21 \%$ da área total do Estado.

Vários estudos realizados nos últimos 20 anos mostraram que o desflorestamento e a variação no tipo e na quantidade da biomassa provocada pela mudança do uso da terra causaram mudanças significativas nos ciclos da água, da concentração de nutrientes, assim como na composição atmosférica (Tian, 1998; Houghton, 2000; Nobre, 2002; Ritchey, 2002).

A discussão em torno da possibilidade de mudanças climáticas em escala global é hoje um tema freqüente na mídia nacional e internacional. Em geral associa-se mudança climática com o aumento de temperatura da atmosfera terrestre pelo aumento do Efeito Estufa, que ocorre devido ao aumento da concentração de certos gases na atmosfera, em especial o $\mathrm{CO}_{2}$. 
Nesse contexto, a Região Amazônica possui um papel fundamental, já que muitos pesquisadores atribuem à região uma capacidade muito grande de influenciar o clima mundial pela liberação ou retenção (seqüestro) do $\mathrm{CO}_{2}$ da atmosfera, que está diretamente ligado às queimadas e mudança do uso da terra.

Entre o aumento da ação antrópica na região Amazônica, a atividade pecuária realizada em pastagens cultivadas tem se destacado, sendo desde 1960, o principal uso econômico da terra. O sistema de formação e manutenção dessas pastagens envolve derrubada da floresta nativa, retirada da madeira economicamente importante, queima da biomassa vegetal e semeadura das forrageiras (Martins, 1996). Estima-se que na Amazônia brasileira cerca de $70 \%$ do total desmatado são usados em algum período como pastagens (Skole, 1994; Fearnside, 1996).

Além de ser um processo de baixo custo, com a queima da biomassa vegetal, muitos nutrientes são disponibilizados às plantas via cinzas da queima, melhorando a fertilidade do solo. Em geral, ocorrem aumentos no $\mathrm{pH}$, no teor de cátions como $\mathrm{Ca}, \mathrm{Mg}, \mathrm{K}$ e redução da acidez trocável (Buschbacher et al., 1988; Moraes et al., 1996; Sanchez et al., 1983), o que possibilita o bom desenvolvimento das pastagens nos primeiros anos pósimplantação.

O problema da região amazônica é que apesar da sua grande exuberância, $75 \%$ da sua área total está estabelecida sobre solos pobres em nutrientes minerais, ficando sua manutenção dependente da ciclagem dos nutrientes contidos na fitomassa. Com isso, os efeitos benéficos das queimadas permanecem por um curto período de atividade pastoril (cinco a oito anos), após o qual verifica-se aumento da infestação por plantas daninhas e declínio na produção e qualidade das pastagens (Fearnside, 1996), começando assim o seu processo de degradação. Nesse momento, as áreas são abandonadas e novamente ocorre à derrubada e queima da floresta para incorporação de novas áreas ao processo produtivo. Segundo o Inpe (2001), mais de 200 mil km² de terra estão abandonadas no momento e/ou em processo de degradação na Amazônia.

Macedo e Zimmer (1993) descrevem a degradação de pastagem como sendo o processo evolutivo de perda de vigor, de produtividade, de capacidade de recuperação natural das pastagens para sustentar os níveis de produção e de qualidade exigido pelos 
animais, assim como, a de superar os efeitos nocivos de pragas, doenças e invasoras em razão do manejo inadequado.

$\mathrm{Na}$ Amazônia Central, a superfície coberta por pastagens em diferentes estágios de degradação é estimada em 12 milhões de hectares, sendo a degradação atribuída à ausência de um controle adequado das plantas daninhas, à pobreza química dos solos e a destruição da estrutura do solo (Barros et al., 1998).

$\mathrm{O}$ uso de maneira racional dos recursos naturais existentes na região amazônica parece ser sem duvida nenhuma, a melhor forma de adequação das necessidades humanas e a preservação desse ecossistema. Para tal é necessário e imprescindível um conhecimento básico profundo do ecossistema e da dinâmica de seus ciclos biogeoquímicos.

A ciclagem da água entre os oceanos, a atmosfera e a bacia de drenagem constituem a principal força motriz dos processos biogeoquímicos que ocorrem na Amazônia (Richey et al., 1990). É necessário e impressindível o entendimento das relações entre as mudanças no uso da terra e os ciclos hidrológicos e biogeoquímicos na região. $\mathrm{O}$ entendimento da hidrologia básica da bacia amazônica é a pedra fundamental para um entendimento mais completo dos ciclos biogeoquímicos e dos processos e mudanças ecológicas que acompanham as mudanças do uso da terra.

\subsection{Mudanças das características do solo pela sucessão floresta/pastagem}

A mudança do uso da terra, de floresta para pastagem, associado à exploração pecuária nos moldes atuais (sem os devidos cuidados agronômicos) causam um desequilibrio no ecossistema e as novas propriedades intrínsecas, influenciam os processos físico-químicos e biológicos do solo, modificando algumas características, tais como, teor e composição da matéria orgânica, complexo argilo-húmico, capacidade de troca de cátions e solução do solo (Velasco \& Lozano, 1979).

Considerando os diversos tipos de uso da terra na região amazônica, a pastagem é provavelmente aquele que causa uma menor degradação ao solo se considerarmos que este é mantido com uma cobertura vegetal o ano todo e que outras práticas de manejo como a aração e gradagem são muito pouco empregadas. Além desses aspectos, as pastagens 
apresentam uma alta capacidade de acumular carbono no solo devido a intensa reciclagem das raízes das gramíneas (Fisher et al., 1994).

O desmatamento, queima da floresta e instalação de pastagens têm ocasionado mudanças no conteúdo e na qualidade da matéria orgânica e nas propriedades físicas e químicas do solo (Maggs e Hewett, 1993).Vários estudos relatam um aumento no pH do solo, no teor de cátions trocáveis e uma redução da acidez trocável devido ao desmatamento e queima da floresta natural (Ewel et al., 1981; Buschbacher et al., 1988; Martins et al., 1991).

Também tem sido demostrado que o desmatamento afeta os conteúdos de carbono e nitrogênio no solo (Cerri et al., 1991; Veldkamp, 1994) e aumenta a liberaçãode $\mathrm{CO}_{2}$ para atmosfera (Houghton, 1990).

Entretanto, com a introdução da pastagem, a quantidade de matéria orgânica do solo normalmente decresce nos primeiros anos de sua implantação, mas posteriormente aumenta até atingir níveis muito próximos aos previamente existentes na mata natural (Cerri \& Adreux, 1990). Esse fato é explicado devido aos ecossistemas naturais apresentarem uma única fonte de origem de carbono orgânico do solo, ou seja, os resíduos vegetais em decomposição, enquanto que nos agrossistemas como as pastagens, a maior parte do carbono do solo apresenta no mínimo duas fontes: a remanescente da vegetação nativa e a produzida pela decomposição dos resíduos vegetais da pastagem (Bernoux et al., 1999).

De modo geral, sabe-se que apesar do aumento da matéria orgânica do solo até concentrações similares à floresta, gerado pela pastagem, a composição química da matéria orgânica proveniente da pastagem é diferente. Porém, não se conhece qual o efeito dessa diferente composição quanto à ciclagem e disponibilidade dos nutrientes em solução do solo ou até que ponto a mudança do uso da terra pode afetar a hidrologia da região amazônica.

\subsection{O carbono nos ecossistemas da região Amazônica}

O ciclo do carbono é o ciclo elementar mais importante da biosfera. A partir da fotossíntese, carbono é fixado em uma forma reduzida na matéria orgânica, produzindo as 
concentrações de oxigênio observadas na atmosfera terrestre (Berner et al., 1983) e os centros localizados de energia potencial para o restante dos processos biogeoquímicos do ambiente (Stumm \& Morgan, 1996).

A baixa fertilidade dos solos na região Amazônica torna a matéria orgânica a principal fonte de nutrientes para as plantas, tornando o ciclo do carbono vital para a sustentabilidade do ecossistema natural ou manejado na Amazônia (Feigl et al., 1995). Atualmente, já se conhece o funcionamento da maior parte do ciclo do carbono na região e vários estudos tem atentado para o conhecimento do funcionamento e das concentrações do carbono nas diferentes partes que compõem seu ciclo.

Além da evidente relevância para o funcionamento dos ecossistemas como o existente na Amazônia, aumentos recentes das concentrações de $\mathrm{CO}_{2}$ e $\mathrm{CH}_{4}$ na atmosfera têm sido apontados como responsáveis pelo aumento do "efeito estufa" (Rasmussen \& Khalil, 1986), situando o elemento no centro das discussões sobre mudanças climáticas globais. Nesse contexto o impacto das mudanças no uso da terra e seus efeitos na região apresentam conseqüências globais com relação às emissões de dióxido de carbono decorrentes do desflorestamento e da queima da biomassa. As emissões anuais de $\mathrm{CO}_{2} \mathrm{na}$ Amazônia são de aproximadamente 150 a 200 megatoneladas de C (Houghton et al., 2000), onde em comparação, no Brasil são emitidos por ano apenas 75 megatoneladas de $\mathrm{C}$ através da queima de combustíveis fósseis.

Keller et al. (1997) em seu estudo, levantaram a questão sobre se a floresta funcionava como um absorvedouro ou uma fonte de carbono para a atmosfera, já que atualmente acredita-se que a floresta Amazônica funciona como um absorvedouro do carbono da atmosfera.

Dados recentes sugerem que as emissões de $\mathrm{CO}_{2}$ brejos existentes na bacia Amazônica podem ser bem maiores do que se imaginavam até agora, podendo contribuir com até $1 \mathrm{Mg}$ de $\mathrm{C} \mathrm{ha}^{-1}$ ano (Richey, 2002) e que o desflorestamento contribui com $1,6 \mathrm{Mg}$ $\mathrm{C}$ ha ano-1 (Houghton, 2000). Steudler et al. (2002) demostraram que a emissão de $\mathrm{CO}_{2} \mathrm{em}$ solos sob pastagem na Amazônia são menores que as emissões de solos sob floresta. Em contrapartida, estudos como o de Phillips et al. (1998) e Malhi et al. (2002) indicam que a floresta Amazônica pode sim funcionar como um absorvedouro de carbono em taxas que vão de 0,8 até a elevada cifra de 7 toneladas de $\mathrm{C} \mathrm{ha}^{-1}$ ano. 
Entretanto deve-se ressaltar que o ciclo do carbono na região Amazônica é bem mais complexo que os fluxos do elemento na forma de gás apresentados em vários trabalhos da literatura atual. O conhecimento básico da participação da hidrologia no ciclo do carbono é de extrema importância para um diagnóstico completo sobre os processos e concentrações do fluxo do carbono na região.

Hope et al. (2001), atenta em seu trabalho, à necessidade de estudos sobre o fluxo do carbono dissolvido na água presente nos solos e nos rios, para assim realizar uma quantificação mais precisa sobre as concentrações do carbono em seu ciclo global. Segundo o autor a ausência desses dados pode gerar uma substimativa da acumulação do carbono no globo terrestre.

Hyndman \& Dallimore (2001), mostraram a relevância da concentração do carbono na fase dissolvida em relação ao total do elemento encontrado no planeta. Apesar da maior quantidade estar na forma de gás com $53 \%$ do total, seguido pelo carbono na forma de combustíveis fosseis $(26 \%)$ e em formas sólidas no solo $(7,44 \%)$, a forma dissolvida aparece com 5,21\% do total, o que é uma quantidade expressiva e de grande importância, pois é nesta forma que o carbono se locomove através das chuvas, pelo solo e posteriormente para rios e oceanos.

Em seu estudo Ritchey et al (1998), apresenta a significativa participação da translocação do carbono, inicialmente fixado pela floresta, entre o solo e pequenos rios, sugerindo a importância em se conhecer a magnitude, dinâmica e conseqüências desta fração no ciclo do carbono.

Para enfatizar ainda mais a importância do carbono orgânico dissolvido vale lembrar que as emissões de $\mathrm{CO}_{2}$ pela superfície da água na região central da Amazônia são de $1,2 \pm 0,3 \mathrm{Mg} \mathrm{C} \mathrm{ha}^{-1} \mathrm{ano}^{-1}$ (Richey et al., 2002) e que são exportados para o oceano pelos rios cerca de $0,4 \mathrm{Gt} \mathrm{C}$ ano $^{-1}$ (Stallard, 1998). Se a fração lábil do carbono é exportada da terra para o sistema aquático é de vital importância que se identifique os processos que controlam a dinâmica da matéria orgânica dissolvida na Amazônia.

Um resumo dos caminhos percorridos pela água em um ecossistema florestal e concentrações do carbono em algumas das diferentes fases de seu ciclo nesse ecossistema são apresentados na Figura 1. 


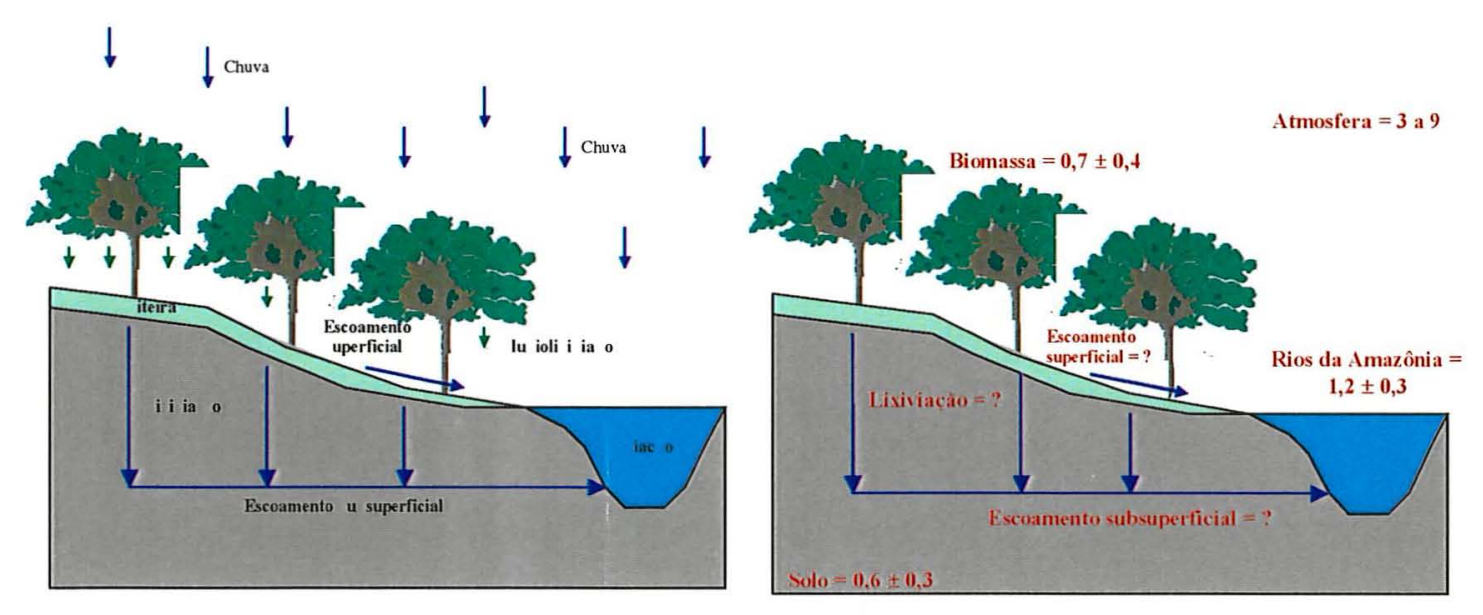

Figura 1 - Caminho da água no ecossistema e concentrações do carbono em um ecossistema florestal. (a) caminhos percorrido pela água da chuva até atingir os rios e riachos; (b) concentrações do carbono ( $\mathrm{Mg} \mathrm{C} \mathrm{ha}^{-1} \mathrm{ano}^{-1}$ ) em algumas das fases que compões seu ciclo (adaptado de Mahli \& Grace 2000).

No processo descrito pela Figura 1, a água da chuva, enriquecida pela passagem através da vegetação, chega ao solo, onde ela pode escoar pela sua superfície ou se infiltrar no solo. Escoando ou infiltrando-se no solo a "solução" entra em contato com galhos e folhas mortas e uma infinidade de organismos vivos que usam esse material no seu metabolismo, participando dos processos de equilíbrio do solo com sua solução. A solução do solo carrega no seu movimento uma quantidade de nutrientes que são reciclados nas diferentes profundidades do solo, retornando à planta através das raízes ou sendo lixiviados. Assim, as avaliações sobre modificações relacionadas com à solução do solo são fundamentais no processo da análise de qualquer ecossistema.

Distúrbios provocados no ciclo hidrológico de uma região, causados pelo desmatamento ou mudança do uso da terra por exemplo, interferem em muitos fatores que mantêm o equilíbrio de um ecossistema natural ou implantado. Assim, a ciclagem de nutrientes é fundamental para esse equilíbrio, envolvendo a entrada de elementos presentes na atmosfera lavados pela água da chuva, participação da vegetação, absorção e lixiviação de nutrientes. 
Apesar de muitos estudos mostrarem os teores de carbono nas mais variadas partes que compõem seu ciclo, o resumo apresentado na figura 1, deixa claro à necessidade de se descobrir qual é a concentração do carbono que está presente no escoamento superficial e na lixiviação, já que esses processos são responsáveis pelo elo de ligação entre o solo e a água dos rios e oceanos, e qual a influência do desflorestamento e da mudança do uso da terra nesses processos.

\subsection{Solução do solo}

A importância do estudo da solução do solo tem sido reconhecida à muito anos. Porém, devido às dificuldades de amostragem e da estimativa das concentrações dos nutrientes, a solução do solo não é usada com mais frequiência na avaliação da qualidade do solo (Smethurst, 2000). Muitas dúvidas ainda persistem no estudo da solução do solo desde sua criação como uma das partes que compõem a química do solo em 1960.

A principal definição de solução do solo foi realizada por Adams (1974, citado por Wolt, 1994) que baseado nas definições de Hilgard (1912), Marbut (1935) e Joffe (1949), definiu solução do solo como sendo a fase liquida do solo e os solutos nela dissolvidos encontrando-se praticamente em equilíbrio com a fase sólida. Com a evolução das pesquisas nessa área, surgiu o termo "água do solo". Segundo Kohnke (1968, citado por Wolt, 1994) a água do solo inclui a solução do solo e a água que percola através desse, não atingindo assim o equilíbrio com a fase sólida.

Wolt (1994) afirmou que em métodos de coletas realizadas a campo não é possível distinguir a solução do solo da água do solo. O termo "água do solo" é derivado de "soil water", termo consagrado na literatura internacional e adaptado a literatura nacional. O termo "água do solo" gera algumas contradições entre os pesquisadores ncionais, devido a sua complexa composição química, já água é usada para expressar uma solução pura. De qualquer forma o uso do termo "solução" parece ser o mais apropriado para as diferentes porções aquosas coletadas do solo, e foi empregada no presente trabalho.

A solução do solo apresenta uma dinâmica muito grande e os elementos que se encontram dissolvidos nessa solução são afetados pela cinética de várias reações tais como, equilíbrio entre ácido e base, complexação iônica, precipitação e dissolução de sólidos, 
oxidação, redução e trocas iônicas (Chaves et al., 1991). Outros processos constituintes desse ambiente também afetam essa disponibilidade, como a planta, a adsorção, a matéria orgânica, tipo de minerais do solo, volatilização e os microorganismos.

A intemperização de minerais primários e secundários representa em regiões temperadas o principal processo de entrada de nutrientes diretamente para a solucão do solo (Cole, 1995). Em regiões tropicais, devido à intensa inteperização dos minerais do solo, a solução do solo apresenta uma baixa concentração de nutrientes (Stark \& Jordan, 1978), o que mostra a necessidade da matéria orgânica como fonte de nutrientes para a solução do solo nos trópicos. Jordan (1982), mostrou em seu trabalho uma forma de avaliar a importância do solo como fonte de nutrientes para um ecossistema: a diferença entre a entrada de nutrientes da atmosfera para o sistema em equilíbrio (florestal) e a saída desses devido à lixiviação é a resposta da liberação de nutrientes pelo solo. Os efeitos da estrutura do solo na lixiviação também são de fundamental importância para a ciclagem de nutrientes, principalmente a agregação e a macroporosidade. A agregação é controlada em parte pela mineralogia do solo e pelo teor de matéria orgânica.

Em geral, os ecossistemas florestais apresentam perdas por lixiviação muito baixas. Segundo Cole (1995) se um sistema florestal apresentar altos níveis de perdas ou o sistema foi derrubado e queimado, ou a entrada de nutrientes fixados da atmosfera ou pela chuva é excessivo. Um estudo realizado na Amazônia Venezuelana por Jordan (1982) a taxa dos nutrientes lixiviados da floresta foram sempre iguais ou menores que a taxa de nutrientes vindos da atmosfera.

As queimadas aumentam severamente a concentração de elementos na solução do solo e seus efeitos são momentâneos (Uhl et al., 1988; Brouwwer, 1996). Aparentemente com a queima de restos orgânicos geralmente acentuam-se também as perdas de elementos através da lixiviação (Weston \& Attiwill, 1990).

Apesar da enorme quantidade de fatores que influenciam a composição da solução do solo, sua forma de obtenção talvez seja o fator mais importante a ser considerado em seu estudo. A estimativa da concentração de elementos na solução do solo depende dos detalhes dos métodos utilizados na sua obtenção e nunca se deve esperar que amostras extraídas no campo representem a atual solução do solo. O estudo da solução do solo nestas condições representa apenas um "momento" em termos de tempo de um sistema dinâmico cuja 
química é controlada por equilíbrios termodinâmicos e por reações de cinética de adsorçãodesorção e preciptação-dissolução (Baham, 1984).

A escolha do método de extração da solução do solo a ser utilizado é extremamente importante, devido principalmente, às possíveis diferenças causadas por cada método na sua composição (Dahlgren, 1993). O uso de diferentes tipos de lisímetros, pressão de sucção (no caso de lisímetros de tensão), períodos de coleta, forma de preparo da solução etc, tem causado inúmeras dificuldades na correlação para qualificação e quantificação das soluções coletas no campo (Santos \& Ribeiro, 1975; Luizão, 1989; Piccolo, 1994; Uhl \& Jordan, 1984).

As técnicas lisimétricas são as mais comulmente utilizadas no estudo da ciclagem de nutrientes. Os dois principais coletores lisimétricos são: o lisimetro de tensão, que realiza a coleta da solução a partir da aplicação de uma pressão negativa, tendo a desvantagem da dificuldade de estabelecer sua zona de influência e o lisímetro de tensão zero, que permite a coleta da água de drenagem (lixiviado), tendo a vantagem de poder ser utilizado para estimar o fluxo dos elementos, através da sua zona de influência.

Os lisímetros de tensão zero, foram utilizados pela primeira vez para coleta de solução do solo por Joffe (1932), e sua utilização tem sido amplamente difundida nos dias de hoje (Song et al, 1993; Giesler, 1996), sua coleta geralmente é realizada por evento, ou seja, quando ocorre a drenagem de solução até a profundidade em que tenha sido instalado o lisímetro. Em contrapartida, os lisímetros de tensão com cápsula porosa permitem a coleta da solução solo com uma certa freqüência que pode variar entre dias, semanas, dependendo do local, e condições climáticas, já que este tipo de lisímetro não depende diretamente da chuva, e sim da umidade e tensão do solo (Piccolo et al., 1994).

Muitos estudos foram realizados comparando-se as soluções obtidas por lisímetros de tensão e de tensão zero. Haines et al. (1982) estudando um solo sob floresta na Carolina do Norte (USA) concluiu que as concentrações nas soluções obtidas pelo lisímetro de tensão são bem maiores que as obtidas através do lisímetro de tensão zero.

Barbee \& Brown (1986) usando lisímetros de tensão e de tensão zero para investigar a lixiviação de cloretos em três tipos de solos, perceberam uma grande diferença na concentração do elemento na solução obtida nos diferentes tipos de coletores. $\mathrm{O}$ mesmo ocorreu com nitrato, possuindo uma menor concentração no lisímetro de tensão zero que na 
solução obtida no lisímetro de tensão no trabalho de Hendershot \& Courchesne (1991). A diferença observada na concentração dos elementos presentes na solução do solo coletada por estes dois tipos de lisímetros, geralmente é explicada por serem soluções diferentes pela origem, pela diferente zona de influência de cada lisímetro, pelos locais de instalação, etc.

Outro fator importante a ser considerado é que a solução do solo nunca é estéril. Então, as atividades dos microorganismos podem causar alterações nas amostras e mascarar a realidade da solução, conseqüentemente, íons de hidrogênio, amônia nitrato e substâncias orgânicas são alguns dos exemplos que podem ser alterados (Grosssmann \& Uldluft, 1991). Nesse contexto deve-se considerar uma metodologia que diminua, ou mesmo anule, os efeitos da atividade microbiana.

Poucos são os estudos que avaliam a concentração do carbono orgânico dissolvido na solução do solo em regiões tropicais, apesar de sua grande importância para essa região. Esse número é ainda mais reduzido se desejarmos obter informações sobre o carbono orgânico dissolvido na solução do solo em área de sucessão floresta/pastagem, como é o caso do estudo em questão. A utilização de diferentes técnicas de coleta da solução do solo nesse estudo (lisímetros de tensão e tensão zero), enriquecem ainda mais as informações obtida, ajudando a compreender melhor o ciclo do carbono na Amazônia e as melhores formas de atuação para os ecossistemas da região.

\subsection{Carbono orgânico dissolvido}

A rápida degradação do solo sob exploração agrícola no mundo, especialmente nos países tropicais em desenvolvimento, despertou nas ultimas décadas, a preocupação com a qualidade do solo e a sustentabilidade da exploração agrícola (Lal \& Pirce, 1991). Desde então, vários conceitos de qualidade do solo foram propostos; o melhor deles porém, define a qualidade do solo como sendo a sua capacidade em manter a produtividade biológica, a qualidade ambiental e a vida vegetal e animal saudável na face da terra (Doran \& Parkin, 1994). Dentre desse conceito, a matéria orgânica do solo se apresenta como um ponto estratégico na manutenção da qualidade dos solos.

As substâncias orgânicas dissolvidas presentes na solução do solo constituem a fração móvel da matéria orgânica e representam uma das partes mais ativas na formação do 
solo e disponibilidade de íons (Nettleton \& MacCraken, 1972). Na literatura as principais reações e interações com o meio, principalmente em ecossistemas tropicais geralmente estão relacionadas ao carbono orgânico dissolvido.

O Carbono orgânico dissolvido está presente no solo principalmente em sua camada superficial e pode exercer uma grande influência sobre o processo de lixiviação iônica, ciclagem de nutrientes, dinâmica da comunidade de microrganismos e intemperismo mineral em solos (Yavitt \& Fahey, 1984; Cronan \& Aiken, 1985). Essa forma de carbono proveniente de produtos do metabolismo e decomposição de plantas, animais e microorganismos, são constituídos basicamente de ácidos fúlvicos, ácidos húmicos e ácidos orgânicos de cadeias curtas (Arzhanova \& Vertel, 1981).

A importância da dinâmica dos íons em soluções causadas pelo carbono orgânico dissolvido em solos tropicais está ligada à concentração de nutrientes nesses solos, que é extremamente baixa se comparada a alguns solos em regiões temperadas (Pavan, 1985 e Moraes, 1991). Essa pequena quantidade de minerais primários que ocorre em solos tropicais, não permite a reposição rápida da concentração de nutrientes na solução do solo quando os nutrientes são absorvidos pelas plantas, lixiviados ou perdidos por escoamento superficial.

Atualmente tem-se atribuído ao carbono orgânico dissolvido (cadeias orgânicas de baixo peso molecular) a capacidade de complexação de íons presentes na solução do solo. Apresentando-se como um ligante orgânico, o carbono orgânico dissolvido apresenta ainda a capacidade de mobilizar $\mathrm{Ca}, \mathrm{Mg}$ e $\mathrm{K}$ em profundidade no solo (Cassiolato, 2001; Meda, 2002; Franchini et al., 1999a; Franchini et al., 1999b, Miyazawa et al., 1992). Nodvin et al. (1986) observaram que os níveis de carbono orgânico dissolvido variaram com o tipo de ânion e a concentração aniônica inicial da solução, sugerindo grande interação entre a solução e a matéria orgânica.

Pesquisadores como Qualls \& Haines (1991), Currie et al.(1996), Dalva \& Moore (1991), entre outros tem demostrado a importância da participação do carbono orgânico na composição da ciclagem de nutrientes em ecossistemas florestais temperados, medindo-o na água da chuva, pluviolixiviado (throughfall) e na solução do solo. Atualmente sabe-se que a mudança no uso da terra afeta a quantidade e a composição do carbono orgânico dissolvido transportado através do solo, porém, pouco se sabe sobre os efeitos desta sua 
nova quantia e composição na solução do solo e na dinâmica e disponibilidade de outros elementos desse ecossistema.

Uhlenhopp et al. (1995), encontraram em seus estudos, que solos com práticas agrícolas aumentaram em 3 a 5 vezes a quantidade de carbono orgânico disssolvido perdida por esses solos em relação a floresta. Essa diminuição do carbono orgânico dissolvido no solo pode estar relacionada com o desequilíbrio do ecossistema, geralmente encontrado em sistemas agrícolas.

A fertilização do solo, comumente usada na agricultura, também pode causar efeitos na concentração de carbono orgânico dissolvido. Currie et al. (1996) determinaram que a adição de nitrogênio em área florestal não alterou o fluxo do carbono orgânico dissolvido. Em contrapartida, Schindler et al. (1992) mostraram que a adubação fosfatada pode causar um aumento na concentração de carbono orgânico dissolvido na solução de solos sob florestas temperadas. Em outro estudo, Dalva \& Moore (1991) estabeleceram que a concentração de carbono orgânico dissolvido presente no sistema pode influenciar a acidez da água, a mobilidade e toxidade de metais e a disponibilidade de nutrientes.

Apesar de ter sido considerado que pequenas espécies de carbono são exportados pelo solo através de escoamento superficial ou lixiviação, é importante lembrar que essa forma de carbono são rapidamente remineralizados (McClain, 1997). Porém, a contribuição do carbono orgânico dissolvido na ciclagem dos nutrientes parece ter uma proporção muito maior que a sua quantidade que participa desse processo do solo. Estudos mostram que o carbono orgânico dissolvido, assim como a matéria orgânica dissolvida podem ser transportados a grandes distâncias pelos corredores fluviais (Hedges et al., 1986). Somente a exportação fluvial de carbono orgânico e inorgânico dissolvidos para os oceanos chega a incrível quantia de $\sim 0.4 \mathrm{Gt} \mathrm{C}$ ano $^{-1}$ (Stallard 1998), sendo que a grande maioria dessa forma dissovida de carbono foi originada no solo.

O importante processo da evolução da matéria orgânica dissolvida do solo para os pequenos rios e posteriormente para os grandes rios são de garnde import6ancia e pouco compreendida (Hedges et al. 2000; Aufdenkampe et al. 2001; Devol and Hedges, 2001). Esse processso constitui uma visão mais completa dos principais processos e mecanismos de degradação, transporte e armazenamento da matéria orgânica e sua participação na ciclagem de nutrientes. 


\section{MATERIAL E MÉTODOS}

Com o objetivo de estabelecer práticas agrícolas adequadas para recuperação de pastagens em processo de degradação na região Amazônica, tendo por base critérios agronômicos, econômicos e ambientais, realizou-se na região um projeto de pesquisa multidiciplinar, que contou com a participação de vários pesquisadores e instituições. Esse projeto, que para todos os efeitos nesse trabalho será tratado como Projeto Temático, era composto de quatro diferentes estratégias de ação para recuperação de pastagens degradadas e um controle (Anexo A). Futuramente os dados obtidos com esse projeto multidiciplinar e seus vários estudos, serão utilizados conjuntamente na tentativa de entender melhor cada situação avaliada.

Aproveitando a estrutura montada para execução do projeto Temático e tendo em vista a importância do carbono do solo para a sustentabilidade do ecossistema natural $\mathrm{e}$ manejado na Amazônia, bem como a necessidade crescente de conhecimento detalhado sobre a ciclagem de nutrientes nesse ambiente, foi desenvolvido paralelamente um estudo relacionado ao fluxo do carbono orgânico e de outros elementos dissolvidos na solução do solo sob pastagem (dois tratamentos do projeto Temático) e sob floresta.

\subsection{Localização geográfica e características climáticas da região}

O projeto Temático e o estudo com solução do solo foram instalados na fazenda Nova Vida ( $10^{\circ} 10^{\prime} 05^{\prime \prime} \mathrm{S}$ e $62^{\circ} 49^{\prime} 27^{\prime \prime} \mathrm{O}$ ), localizada no município de Ariquemes, km 472 da BR-364, região central do Estado de Rondônia, à aproximadamente $250 \mathrm{~km}$ ao sul da cidade de Porto Velho, à sudoeste da bacia Amazônica Brasileira. A Figura 2 ilustra a localização da fazenda. 


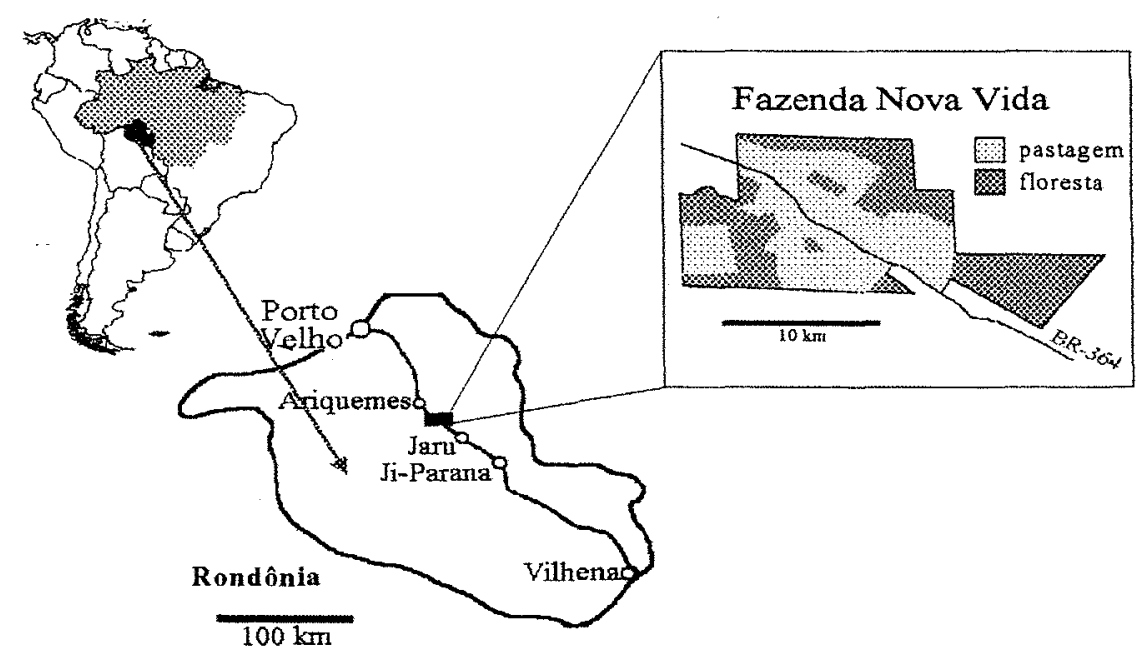

Figura 2 - Localização da Fazenda Nova Vida, município de Ariquemes-RO.

O clima da região central de Rondônia é classificado, segundo a classificação de Köppen, como tropical úmido, tipo Awi, apresentando uma estação seca bem definida entre os meses de junho e agosto (Bastos \& Diniz, 1982).

Para melhor controle das flutuações climáticas da região estudada, foram obtidos dados pluviométricos na própria fazenda e reunidos valores de temperatura, deficiência hídrica e excedente hídrico do solo provenientes da estação meteorológica do CEPLAC em Ouro Preto d'Oeste, distante aproximadamente $100 \mathrm{~km}$ do local do experimento.

A precipitação média anual calculada com dados referentes ao período de 1993 a 2000 é de $2473 \mathrm{~mm}$. Analisando a linha de tendência das precipitações mensais da fazenda (Figura 2), nota-se uma variação bem definida, com ocorrência máxima de precipitação no período de novembro a março, representando $75 \%$ do total de chuva anual e com nenhum mês do período considerado apresentando menos de $290 \mathrm{~mm}$.

A temperatura média do ar, calculada com dados referentes ao período de 1993 a 1999 é de $24,6^{\circ} \mathrm{C}$, sendo que a temperatura média mais elevada ocorre no mês de outubro, $25,7{ }^{\circ} \mathrm{C}$, enquanto a mais baixa no mês de julho, $22,9{ }^{\circ} \mathrm{C}$ (Figura 3). Observa-se que a variação anual das temperaturas médias é pequena $\left(2,8^{\circ} \mathrm{C}\right)$ e que sofrem uma queda nos meses de junho a agosto, motivada pelo fenômeno da friagem. A média anual da umidade relativa do ar se encontra em torno de $89 \%$ (Scerne et al., 2000). 


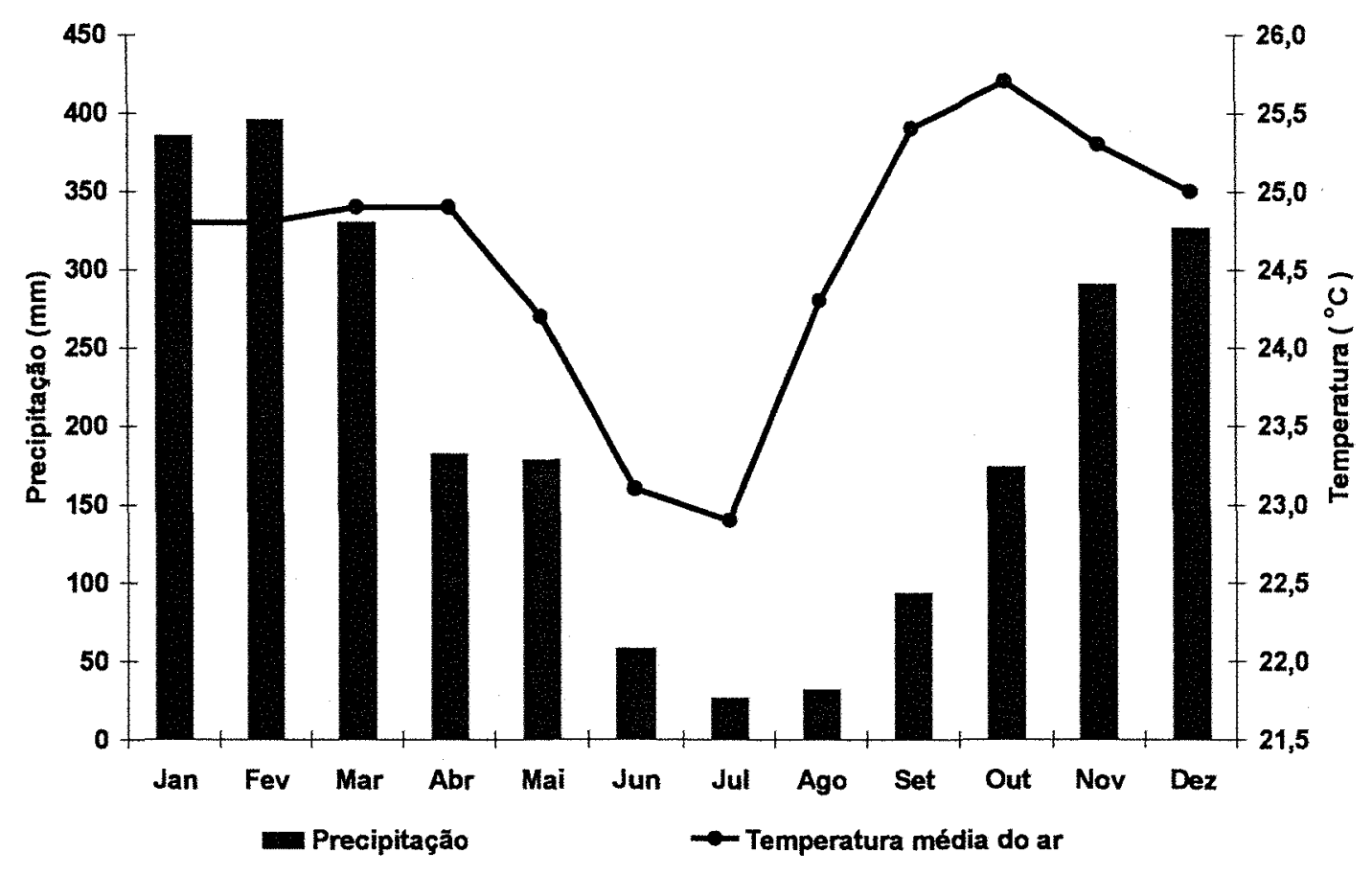

Figura 3 - Variação média mensal da precipitação (1993 - 2000) e da temperatura média do ar na região estudada.

A Tabela 1 apresenta os valores médios mensais da deficiência e do excedente hídrico no solo da região de Ouro Preto d'Oeste no período de 1993 a 1999 (Scerne et al., 2000). Nota-se que no período de maio a outubro, os solos da região apresentam déficit hídrico em torno de $217 \mathrm{~mm}$, o que caracteriza a estação seca. Em contrapartida nos meses de novembro a abril ocorre um excedente hídrico no solo de aproximadamente $600 \mathrm{~mm}$, caracterizando a estação chuvosa.

Analisando em conjunto os dados referentes à precipitação e a retenção hídrica do solo, observa-se que o mês de outubro, mesmo com ocorrência de deficiência hídrica, apresenta uma quantidade de chuva razoável, sendo um mês de reposição hídrica no solo. 
Tabela 1. Valores médios mensais da deficiência e do excedente hídrico no solo segundo o método de Thornthwaite e Mather (1995), considerando $125 \mathrm{~mm}$ de retenção hídrica, período de 1993 a 1999.

\begin{tabular}{ccc}
\hline Mês & Deficiência hídrica no solo & Excedente hídrico no solo \\
\hline Janeiro & $\mathrm{mm}$ & $\mathrm{mm}$ \\
Fevereiro & 0 & 135 \\
Março & 0 & 123 \\
Abril & 0 & 137 \\
Maio & 0 & 55 \\
Junho & 4 & 0 \\
Julho & 32 & 0 \\
Agosto & 55 & 0 \\
Setembro & 67 & 0 \\
Outubro & 50 & 0 \\
Novembro & 9 & 0 \\
Dezembro & 0 & 35 \\
\hline
\end{tabular}

Fonte Scerne et al., 2002.

\subsection{Descrição da área experimental}

As amostras referentes ao presente trabalho de solução do solo foram coletadas de janeiro a maio de 2002, utilizando-se duas áreas, uma sob floresta e outra sob pastagem (Figura 4).

$\mathrm{Na}$ área experimental sob pastagem (projeto Temático), foram escolhidos dois tratamentos para avaliação das características relacionadas à solução do solo e ao carbono orgânico dissolvido. A área sob pastagem localizava-se a 3,5 km da área experimental sob floresta e ambas apresentavam o mesmo solo. Na floresta, a área experimental foi instalada a $200 \mathrm{~m}$ da divisa da margem florestal, visando com isso garantir um local com a mínima interferência antrópica. 


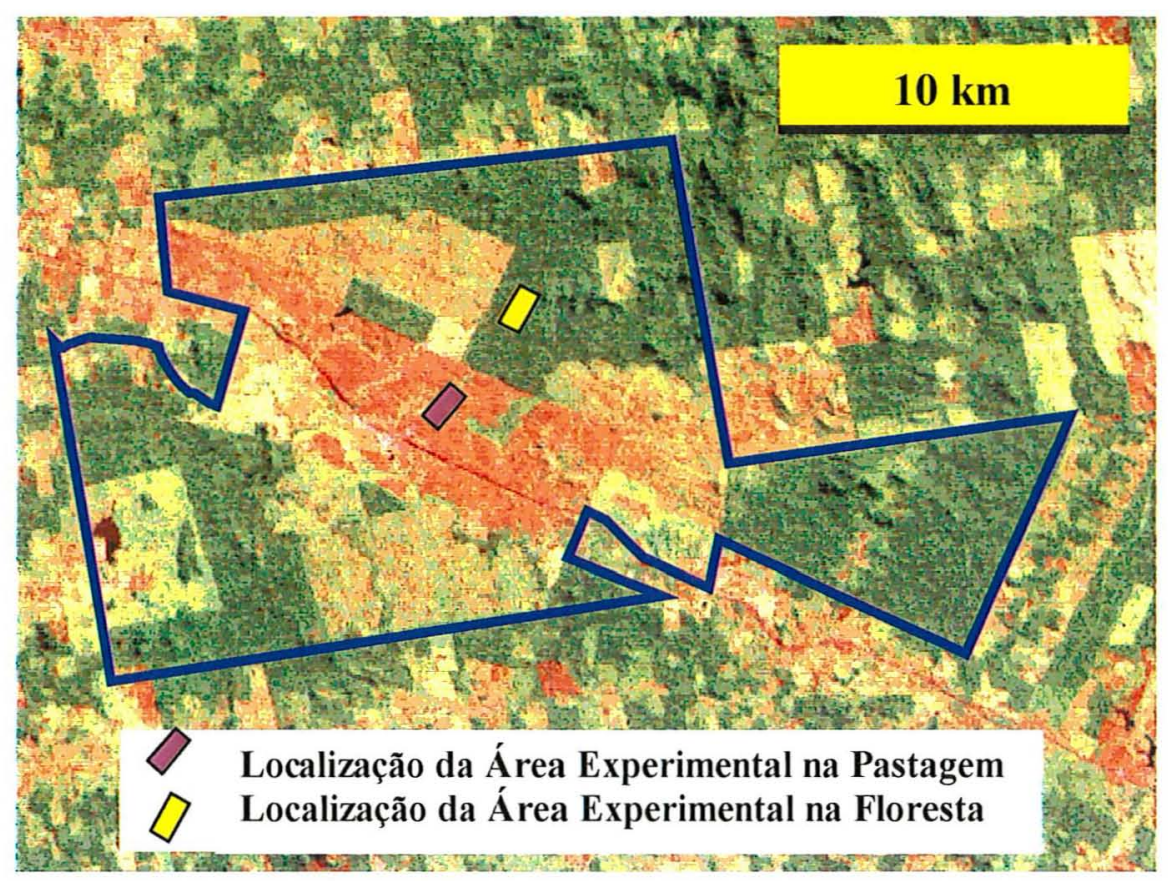

Figura 4 - Mapa de uso da terra com os limites da fazenda Nova Vida e localização das áreas experimentais na Floresta e na Pastagem (Adaptado de Moraes, 1995).

A escolha da área para instalação do projeto Temático foi realizada através de um estudo prévio usando análises geostatísticas com dados de variabilidade da área (Cerri et al., 2002), de modo a selecionar de um total de 63 ha com pastagem de Brachiaria brizanta (Figura 5a), uma área de 3,5 ha a priori homogênea (Figura 5b).

Os quatro tratamentos mais o controle do projeto Temático foram instalados no campo em um delineamento em blocos casualizados com quatro repetições, totalizando 20 parcelas. As parcelas do projeto temático possuíam 40 x $40 \mathrm{~m}\left(1600 \mathrm{~m}^{2}\right)$, com área útil de $30 \times 30 \mathrm{~m}\left(900 \mathrm{~m}^{2}\right)$.

De acordo com o histórico da Fazenda, nenhuma prática mecanizada ou aplicação de fertilizantes químicos foi utilizada desde a instalação do pasto e sua taxa de lotação sempre foi menor a 1,5 animal por ha. Tal pastagem, estabelecida em 1983, tem apresentado um processo evolutivo de degradação caracterizado pelo declínio da produtividade e aceleração do grau de infestação por plantas invasoras.

Segundo a classificação de fases de degradação de pastagens, estabelecida por Spain e Gualdron (1988) citados por Moreira e Assad (1998), a pastagem em questão se 
encontra em um estágio de forte degradação, pois possui baixa população vegetativa, baixo vigor e qualidade e por possuir quantidades elevadas de invasoras.

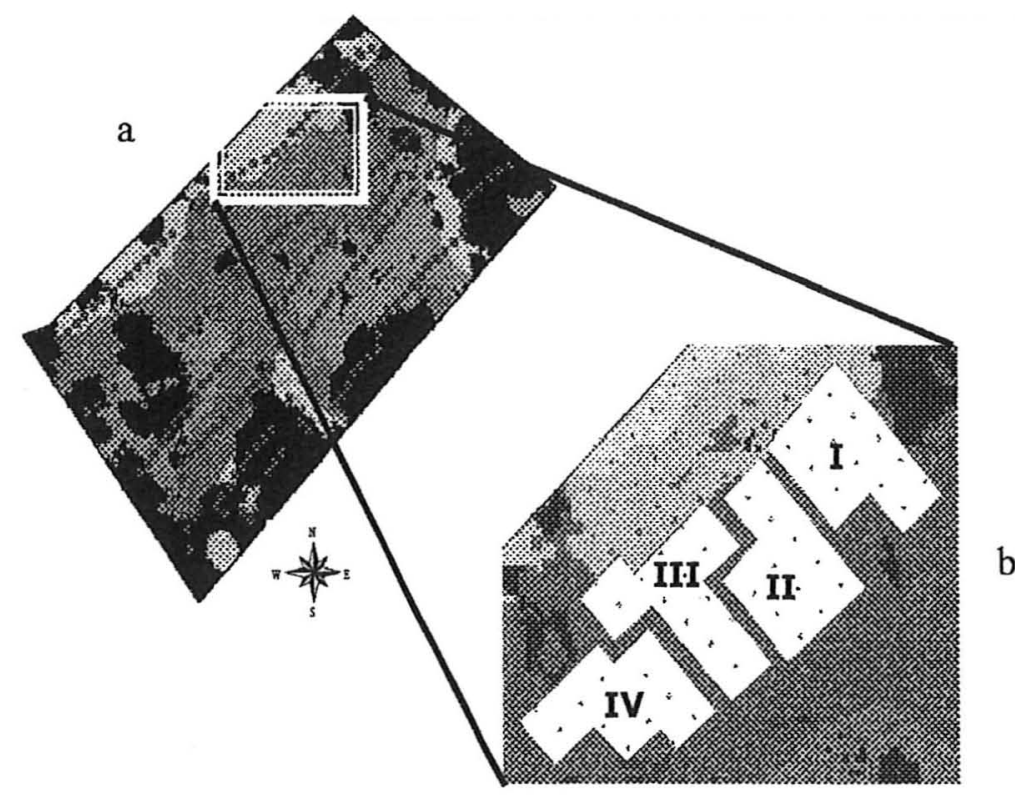

Figura 5 - Área experimental de pastagem de 63 ha selecionada para a introdução do Projeto temático da FAPESP (a) e escolha do local mais homogêneo para instalação dos blocos com os tratamentos do projeto (b) (Cerri et al., 2002).

Os tratamentos avaliados com relação à solução do solo, dois sob pastagem (Controle e Manejo com Fertilização e Gradagem) e um sob floresta, estão descritos na Tabela 2. Os tratamentos eram compostos por três repetições, totalizando 9 parcelas, sendo que as parcelas sob floresta apresentavam o mesmo perímetro das parcelas sob pastagem. Para esse trabalho foi utilizado Floresta para indicar o tratamento instalado na área sob floresta, controle para a pastagem testemunha, e o termo gradagem para a pastagem manejada com fertilização e gradagem. Na Tabela 2 também são apresentados os objetivos de cada um dos tratamentos e as práticas agronômicas envolvidas. 
Tabela 2. Relação dos princípios/objetivos e práticas agronômicas de cada tratamento.

\begin{tabular}{|c|c|c|c|}
\hline & Tratamentos & Princípios/Objetivos & Práticas agronômicas \\
\hline 1 & $\begin{array}{l}\text { Floresta } \\
\text { Áreas escolhidas dentro da reserva } \\
\text { florestal da fazenda. }\end{array}$ & $\begin{array}{l}\text { Comparação com os outros } \\
\text { dois diferentes tipos de uso da } \\
\text { terra. Sistema em equilibrio. }\end{array}$ & \\
\hline 2 & $\begin{array}{c}\text { Controle } \\
\text { Pastagem degradada de B. brizantha }\end{array}$ & Sistema de manejo atual. & $\begin{array}{c}\text { Roçada com máquina uma vez } \\
\text { por ano }\end{array}$ \\
\hline 3 & $\begin{array}{l}\text { Gradagem } \\
\text { Duas gradagens (uma aradora e uma } \\
\text { niveladora) e Semeadura de } B . \\
\text { brizantha. + adubação com N, P, K e } \\
\text { micronutrientes. }\end{array}$ & $\begin{array}{l}\text { Controle de plantas invasoras; } \\
\text { incorporação de biomassa } \\
\text { vegetal; aumento de } \\
\text { produtividade pela melhoria } \\
\text { da fertilidade do solo. }\end{array}$ & $\begin{array}{l}\text { Aplicação de fertilizantes (análise } \\
\text { de solo), gradagem aradora no } \\
\text { início da estação chuvosa e } \\
\text { gradagem niveladora antes da } \\
\text { semeadura de } B \text {. Brizantha }\end{array}$ \\
\hline
\end{tabular}

A adubação realizada no tratamento Gradagem, consistiu na aplicação de $42 \mathrm{~kg}$ $\mathrm{ha}^{-1}$ de $\mathrm{N}, 75,5 \mathrm{~kg} \mathrm{ha}^{-1}$ de P, 26,5 $\mathrm{kg} \mathrm{ha}^{-1}$ de $\mathrm{K}, 204 \mathrm{~kg} \mathrm{ha}^{-1}$ de Ca, 71,4 $\mathrm{kg} \mathrm{ha}^{-1} \mathrm{de} \mathrm{Mg}$, $88,8 \mathrm{~kg} \mathrm{ha}^{-1}$ de S e $30 \mathrm{~kg} \mathrm{ha}^{-1}$ de micronutrientes (Fritas Br12).

A Figura 6 mostra o delineamento experimental do projeto temático e os dois tratamentos utilizados no experimento de solução do solo com suas três repetições.

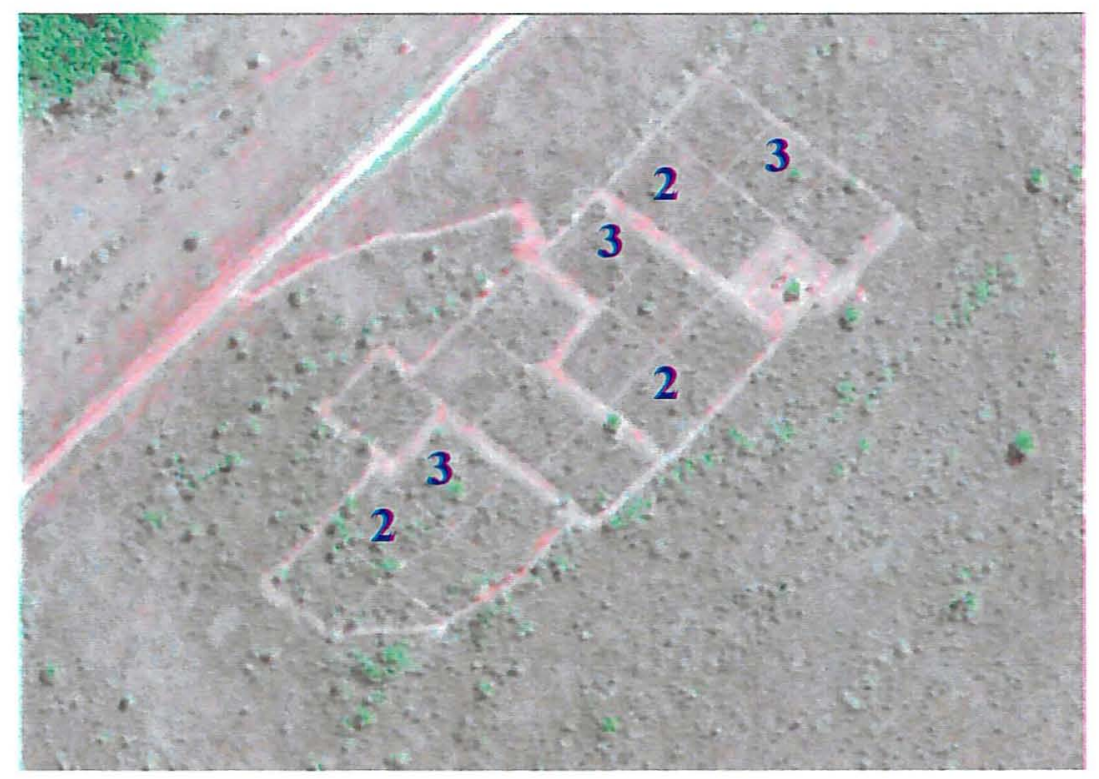

Figura 6 - Imagem de satélite do projeto temático e indicação dos tratamentos de controle (2) e manejo com gradagem (3) utilizados no experimento de solução do solo. 
Os solos que predominam na fazenda foram classificados como ARGISSOLOS, os quais são constituídos por material mineral com argilas de atividade baixa e presença do horizonte B-textural. Este tipo de solo cobre mais de 100 milhões de hectares na Bacia Amazônica Brasileira (Moraes et al., 1995).

Os solos das áreas de estudo foram classificados como sendo ARGISSOLOS VERMELHO-AMARELOS distróficos latossólicos, na classificação da EMBRAPA (1999). Na classificação da FAO-UNESCO este solo corresponde ao Plinthic Acrisol e Typic Plinthudult na classificação Soil taxonomy. Na Tabela 3 observa-se as características da classificação do perfil do solo e na Tabela 4 pode-se observar os teores de argila, densidade as características químicas da área experimental.

Tabela 3. Características da classificação do perfil do solo.

\begin{tabular}{rccc}
\hline Profundidade & Horizonte & Cor & Estrutura \\
\hline $0-5 \mathrm{~cm}$ & $\mathrm{~A}$ & 7.5 YR $4 / 6$ & Granular \\
$5-10 \mathrm{~cm}$ & $\mathrm{~A}$ & 7.5 YR $4 / 6$ & Blocos fracamente desenvolvidos \\
$10-20 \mathrm{~cm}$ & $\mathrm{AB}$ & 7.5 YR $4 / 6$ & Blocos fracamente desenvolvidos \\
$20-30 \mathrm{~cm}$ & $\mathrm{AB}$ & 7.5 YR $4 / 6$ & Blocos fracamente desenvolvidos \\
$30-40 \mathrm{~cm}$ & $\mathrm{BA}$ & 7.5 YR $5 / 6$ & Blocos fracamente desenvolvidos \\
$40-60 \mathrm{~cm}$ & $\mathrm{BA}$ & 7.5 YR $5 / 6$ & Blocos fracamente desenvolvidos \\
$60-80 \mathrm{~cm}$ & $\mathrm{~B} 12$ & 7.5 YR $5 / 6$ & Blocos fracamente desenvolvidos \\
$80-100 \mathrm{~cm}$ & B21 & 7.5 YR $5 / 6$ & Blocos fracamente desenvolvidos \\
\hline
\end{tabular}

Tabela 4. Teores de argila, densidade, $\mathrm{pH}\left(\mathrm{CaCl}_{2}\right)$ e caracterização química do solo na área experimental.

\begin{tabular}{lccccccccc}
\hline Profundidade & Argila & Densidade & $\mathrm{pH}$ & $\mathrm{C}$ & $\mathrm{N}$ & $\mathrm{Al}+\mathrm{H}$ & $\mathrm{Ca}$ & $\mathrm{Mg}$ & $\mathrm{K}$ \\
\hline \multicolumn{1}{c}{$\mathrm{cm}$} & $\%$ & $\mathrm{~g} \mathrm{~cm}^{-3}$ & & $-\cdots--\%$ & $-\cdots$ & $\cdots$ & $-\cdots$ & mmol $_{\mathrm{dm}}^{-3}$ & $-\cdots$ \\
$0-5$ & 23 & 1,35 & 4,90 & 1,76 & 0,12 & 23,99 & 22,3 & 7,23 & 2,47 \\
$5-10$ & 26 & 1,50 & 4,76 & 1,12 & 0,09 & 24,08 & 16,7 & 5,07 & 1,95 \\
$10-20$ & 31 & 1,65 & 4,68 & 0,91 & 0,08 & 20,45 & 12,1 & 3,18 & 1,23 \\
$20-30$ & 33 & 1,65 & 4,58 & 0,73 & 0,06 & 18,88 & 9,1 & 2,41 & 0,81 \\
\hline
\end{tabular}




\subsection{Coleta das amostras}

O estudo da solução do solo e do fluxo dos elementos é muito complexo, e envolve várias dificuldades bastante conhecidas na ciência do solo. Essas dificuldades fazem com que se busquem técnicas e recursos para o completo entendimento das características da solução do solo, ajudando assim na interpretação dos resultados obtidos. Para o presente trabalho realizou-se a coleta de amostras de solo, água da chuva, pluviolixiviado, solução de escoamento superficial, solução do solo e solução lixiviada (Figura 7).

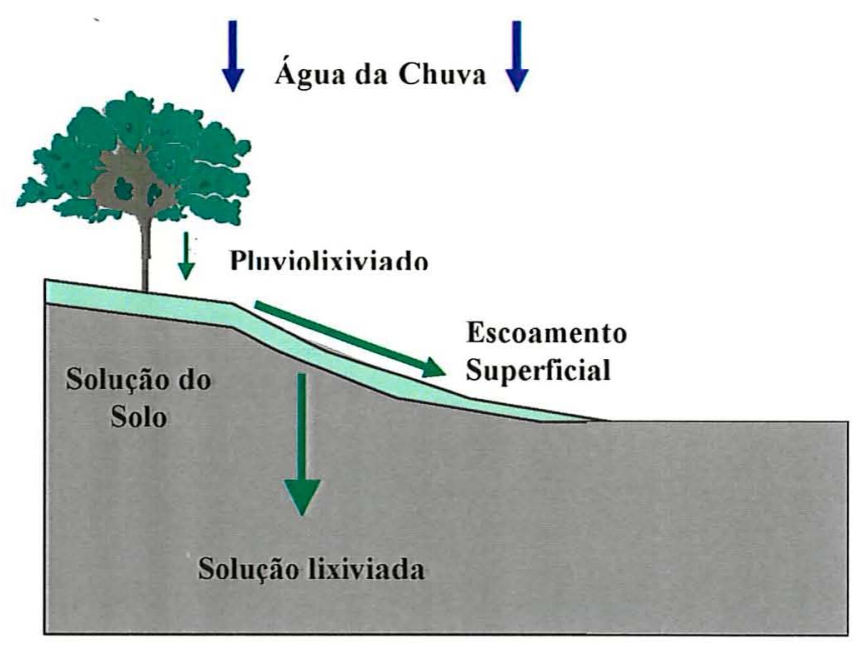

Figura 7 - Disposição das soluções coletadas para analise e estimativa do fluxo do carbono orgânico disssolvido.

\subsubsection{Solo}

Foi coletada uma amostra composta por parcela, constituídas de três amostras simples, em quatro profundidades $(0-5,5-10,10-20,20-30 \mathrm{~cm})$. O carbono e o valor de $\mathrm{pH}$ foram avaliados antes do início do experimento, no mês de outubro de 2001. 


\subsection{2 Água da chuva}

A água da chuva foi coletada usando seis pluviômetros instalados na área experimental ( 2 na área sob floresta e 4 na área sob pastagem). Os pluviômetros eram compostos por um funil com $10 \mathrm{~cm}$ de diâmetro acoplado a um reservatório feito de material plástico que era apoiado em um suporte de madeira à $1 \mathrm{~m}$ do solo, nivelado paralelamente a esse. Na porção superior dos funis foram colocadas telas plásticas visando evitar a contaminação pela entrada de qualquer material trazido pela água da chuva ou pelo vento (insetos mortos, folhas, etc). A água da chuva era coletada por evento, ou seja, após cada precipitação. $\mathrm{O}$ volume total coletado nos pluviômetros era reunido em uma amostra composta que era encaminhada ao laboratório da fazenda onde era preparada, preservada e refrigerada até às analises químicas serem realizadas.

\subsubsection{Pluviolixiviado}

Instalou-se na floresta três coletores eqüidistantes de pluviolixiviados em uma área homogênea, pouco perturbada por ações antrópicas e que representava a diversidade das espécies pertencentes a composição vegetal desta floresta.

Estes coletores foram construídos a partir de laminas de zinco, formando uma calha em " $U$ " com dimensões de $0,1 \mathrm{~m}$ de largura e $6 \mathrm{~m}$ de comprimento $\left(0,6 \mathrm{~m}^{2}\right)$. Essas calhas foram cobertas com tela de nylon de malha $2 \mathrm{~mm}$ para evitar a contaminação pela entrada de qualquer material trazido pela água da chuva ou vento (Figura 8b).

Para criar uma leve declividade no coletor que permitisse o encaminhamento da solução para o reservatório de coleta, cada ponta do coletor foi fixada a uma diferente altura (Figura 8a). As coletas das amostras foram realizadas após cada precipitação pluviométrica. 
a

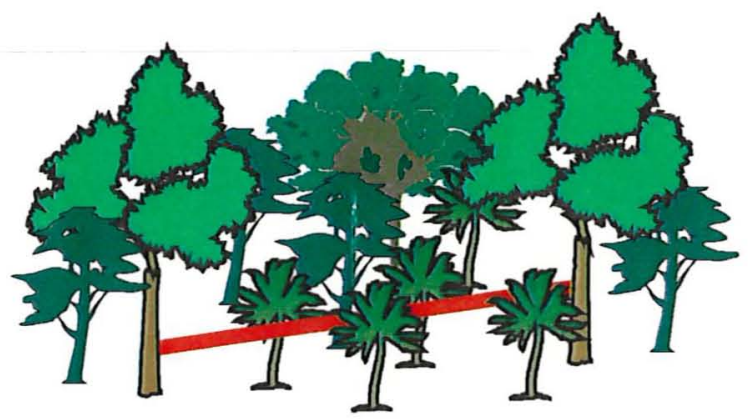

b
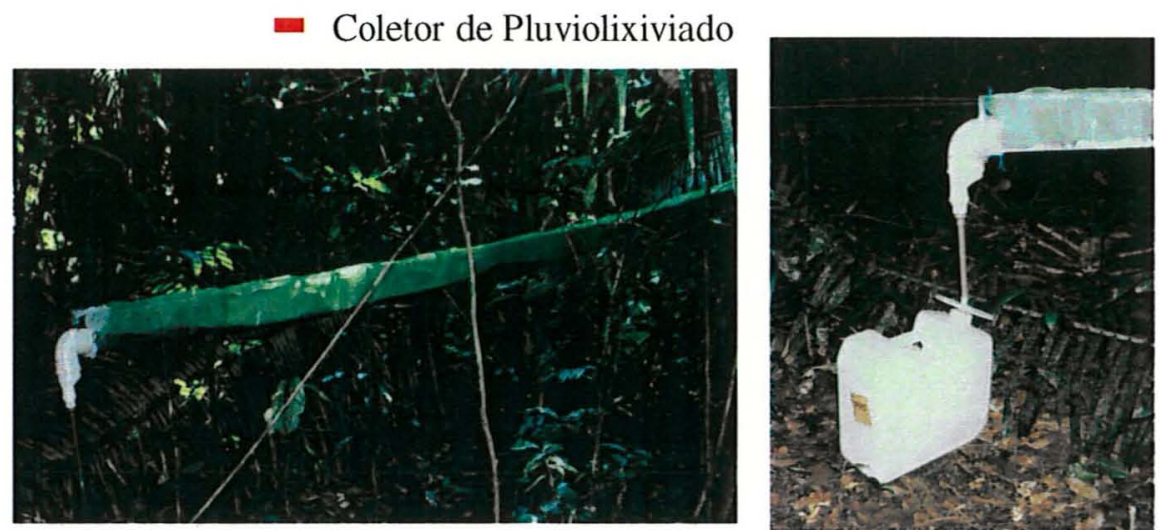

Figura 8 - Coletor de pluviolixiviado. (a) Esquema do posicionamento do coletor de pluviolixiviado (b) fotos mostrando o coletor instalado na área de floresta.

\subsubsection{Disposição dos coletores das soluções do solo}

Considerando as soluções de escoamento superficial, solução do solo e solução lixiviada do solo todas como solução do solo, suas coletas foram realizadas por três diferentes tipos de coletores: o coletor solução de escoamento superficial, o lisímetro de tensão e o lisímetro de tensão zero.

Os três coletores foram instalados no campo em uma área delimitada de $4 \mathrm{~m}^{2}$ (Figura 9a), inclusa na área útil $\left(30 \times 30 \mathrm{~m}^{2}\right)$ de cada tratamento. Em cada parcela do experimento, instalaram-se dois lisímetros de tensão para coleta da solução do solo, distantes entre si aproximadamente $2 \mathrm{~m}$; um lisímetro de tensão zero, instalado a $1 \mathrm{~m}$ de profundidade para coleta da solução lixiviada; e um coletor de solução de escoamento superficial com 2 m de comprimento (Figura 9b). 
A disposição dos três coletores em uma pequena área de $4 \mathrm{~m}^{2}$ visou reduzir a variabilidade natural do solo e de suas características físicas e químicas que podem interferir na composição e concentração de espécies químicas destas soluções.

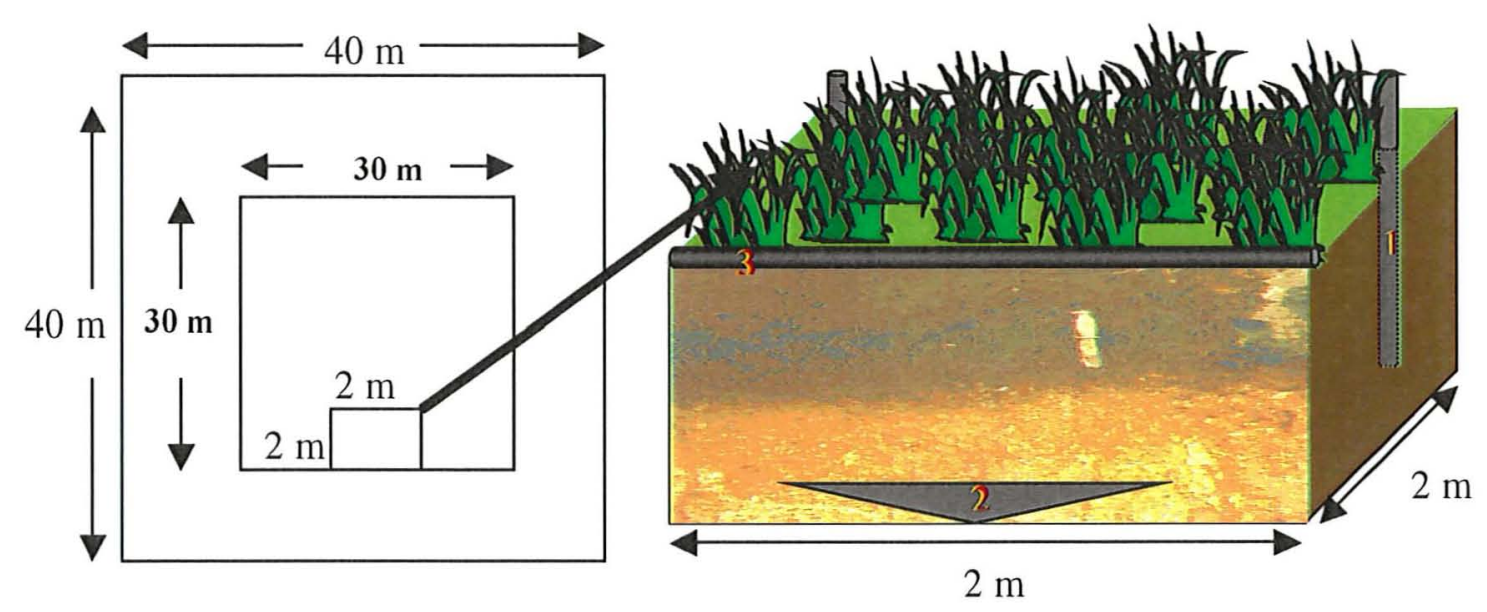

a

b

Figura 9 - Esquema para coleta das soluções do solo. (a) Localização da área de $4 \mathrm{~m}^{2}$ na parcela para coleta da solução do solo (b) esquema de disposição dos lisímetros de tensão (1), tensão zero (2) e coletor de água em escoamento superficial (3), usados respectivamente na coleta da solução do solo, água de drenagem, água de escoamento superficial.

A instalação de dois lisímetros de tensão em cada tratamento de área de $4 \mathrm{~m}^{2}$ foi realizada admitindo-se que a solução seria bem semelhante, para que assim se obtivesse a quantidade necessária de solução do solo requerida para todas as análises. Após a coleta a solução desses dói lisímetros de tensão de cada área era unida, formando uma amostra composta com um maior volume.

A foto aérea do projeto Temático (Figura 10) mostra uma das áreas de $4 \mathrm{~m}^{2}$ selecionada dentro da parcela controle do bloco 2. Nessa área foram instalados os coletores de escoamento superficial e os lisímetros de tensão e de tensão zero. 


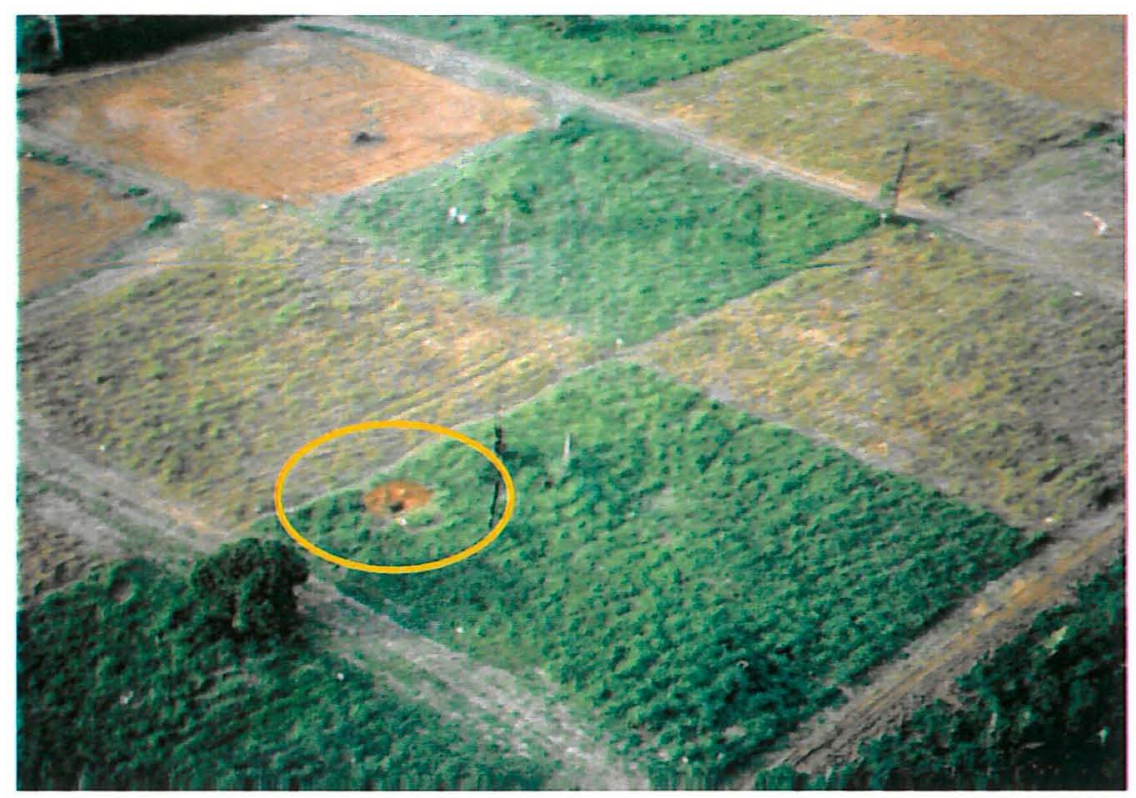

Figura 10 - Foto aérea do experimento com indicação da área de $4 \mathrm{~m}^{2}$ onde se instalou o coletor escoamento superficial e os lisímetros de tensão e de tensão zero.

\subsubsection{Escoamento superficial}

A solução de escoamento superficial foi coletada em uma calha, construída com um tubo de PVC de $2 \mathrm{~m}$ de comprimento e 5" de diâmetro cortado ao meio. Esse equipamento foi enterrado na parte mais baixa de cada área de $4 \mathrm{~m}^{2}$ (Figura 11), ficando a mesma altura da superfície do solo com declividade de $2 \%$, permitindo assim o fluxo da solução em direção ao reservatório.

A área de $4 \mathrm{~m}^{2}$ foi isolada para que toda solução de escoamento superficial coletada fosse proveniente apenas do seu interior. $\mathrm{O}$ isolamento foi realizado com laminas de zinco de $0,35 \mathrm{~m}$ de altura, enterradas no solo no limite da área de $4 \mathrm{~m}^{2}$ à profundidade de $15 \mathrm{~cm}$.

A solução recolhida por esse coletor foi armazenada em reservatório, onde, a exemplo da água da chuva, era coletada logo após cada precipitação pluviométrica. Esse reservatório foi instalado na mesma fossa de coleta utilizada para coleta da solução de drenagem vertical do solo (Figura 16).

A calha de PVC foi coberta com uma telha de plástico prensado, evitando assim que a água da chuva entrasse em contato diretamente com a solução de escoamento 
superficial, isto é, sem ter contato com a superfície do solo (Figura 11). Essa cobertura foi instalada rente ao chão e a água da chuva que caía sobre ela, era guiada para fora da área isolada evitando assim qualquer tipo de contaminação.
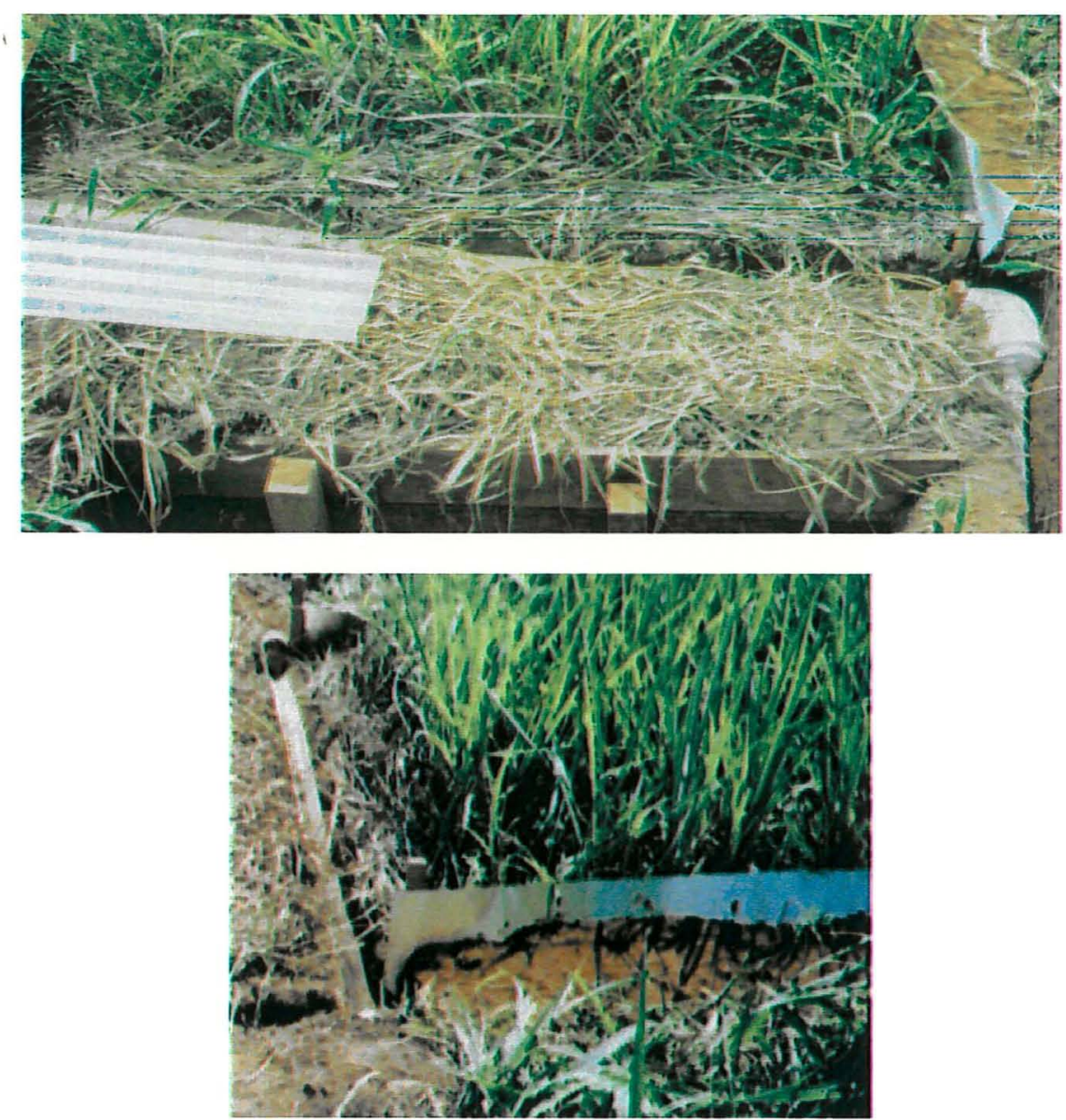

Figura 11 - Coletor de solução de escoamento superficial de PVC instalado no campo, detalhe do delimitamento da área de $4 \mathrm{~m}^{2}$ com lamina de zinco e telha de plástico usada para cobrir o coletor.

\subsubsection{Solução do solo}

A coleta da solução do solo com lisímetros de tensão em cada parcela foi realizada através de dois lisímetros instalados em cada uma das áreas de $4 \mathrm{~m}^{2}$ à profundidade de $1 \mathrm{~m}$ (Figura 12). A coleta foi realizada a cada cinco dias no período de 
janeiro a maio. Esse planejamento de amostragem permitiu registrar as mais importantes mudanças ocorridas na solução do solo durante a estação chuvosa do ano de 2002.

Os dispositivos constituíam-se de cápsulas lisimétricas porosas de 0,05 m de diâmetro, acopladas a tubos plásticos, os quais eram ligados a garrafas de vidro por meio de tubos plásticos finos. A coleta da solução do solo foi realizada 24 horas após a aplicação do vácuo (15 polegadas ou 50 centibars) no lisímetro. O vácuo era realizado com um bomba de sucção manual que era conectada a um tubo plástico fino existente na parte superior do lisímetro.
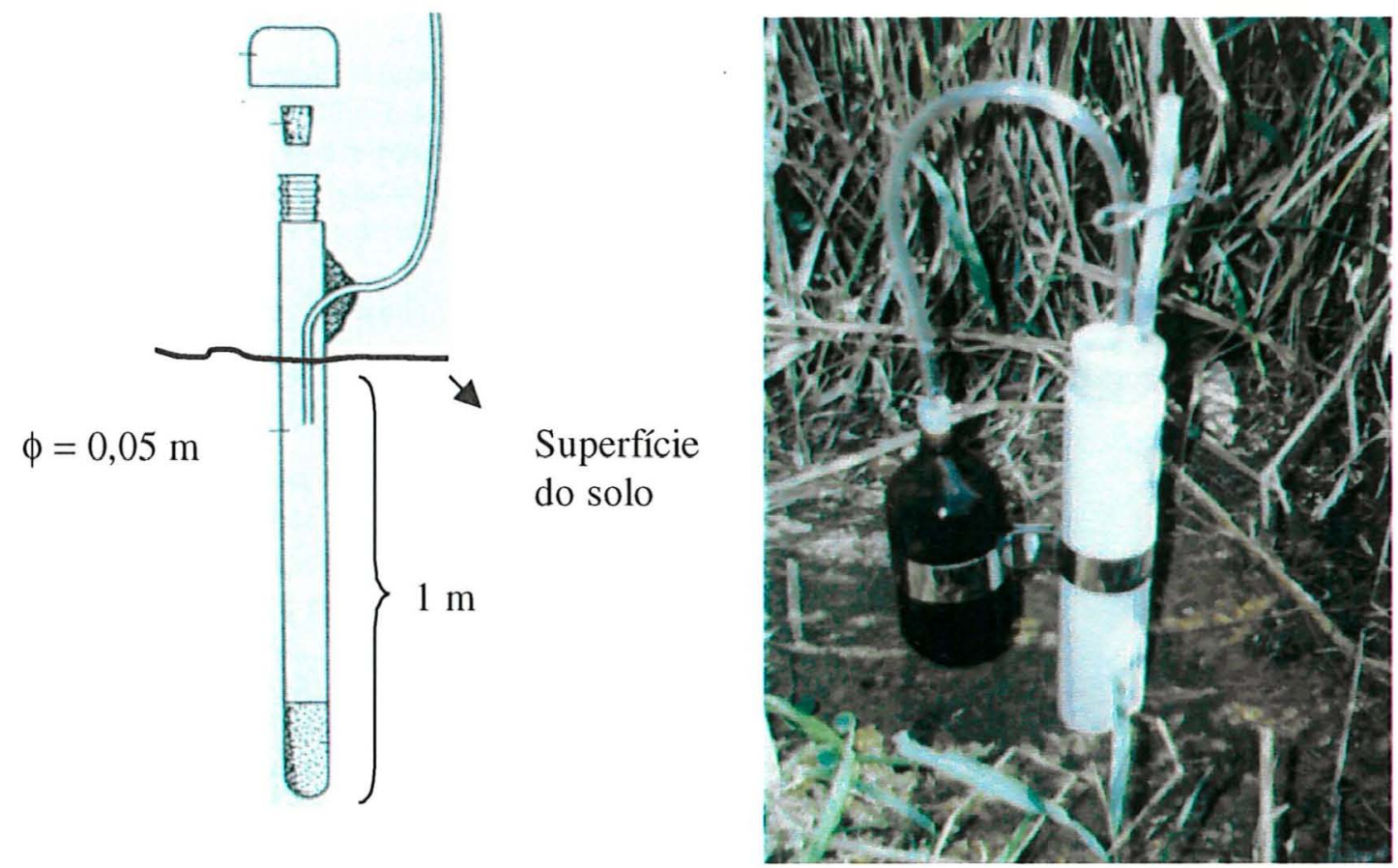

Figura 12 - Desenho da estrutura e foto no campo do lísímetro de tensão utilizado para coleta da solução do solo.

\subsubsection{Solução lixiviada do solo}

A solução de lixiviada do solo foi coletada, através de lisímetros de tensão zero. Esses lisímetros foram instalados a $1 \mathrm{~m}$ de profundidade, através de uma fossa temporária. A Figura 13 mostra em um corte vertical do solo, uma vista geral do lisímetro de tensão zero instalado no solo e pronto para a coleta da solução lixiviada. 


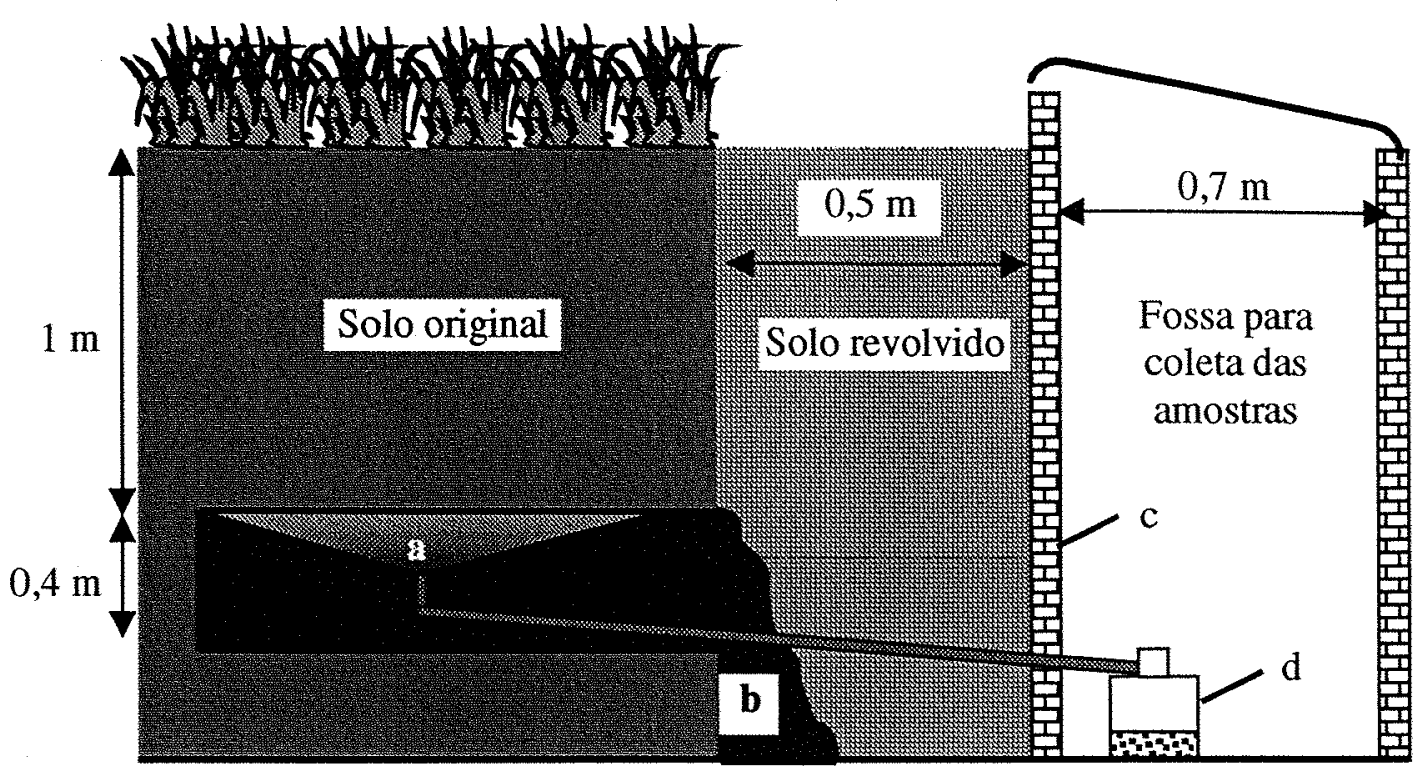

Figura 13 - Esquema da coleta da solução do solo com lisímetro de tensão zero, adaptado de Roose \& Tureaux, 1970. (a) lisímetro de tensão zero instalado no túnel, (b) esquema da vedação do túnel (c) parede de madeira para escoramento da parte da trincheira enterrada e (d) reservatório de coleta da solução lixiviada.

Esses lisímetros de tensão zero eram constituídos de duas partes: i) cone invertido e ii) tubo guia. As duas partes foram construídas em aço inoxidável, material inerte, ideal para evitar a interferência na composição química das soluções.

$\mathrm{O}$ cone invertido possuía $0,96 \mathrm{~m}$ de diâmetro e $0,3 \mathrm{~m}$ de altura, e era a parte responsável pela coleta da solução que drenava do solo. O tubo guia possuía 1,50 m de comprimento e 1,5 " de diâmetro e era responsável pela condução da solução até o reservatório de coleta, a solução se movia dentro do tubo devido à sua inclinação de $2 \%$ realizada na construção do lisímetro (Figura 14). 

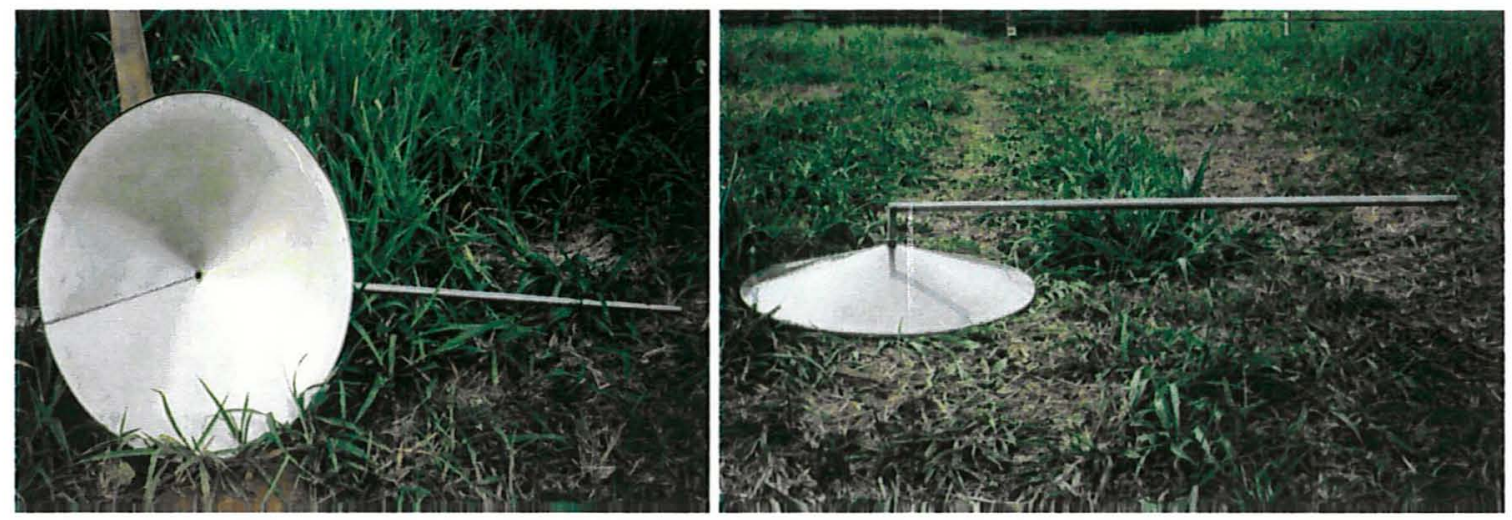

Figura 14 - Lisímetro de tensão zero utilizado na coleta da solução lixiviada do solo

A primeira etapa realizada na instalação dos lisímetros no solo foi cavar as nove trincheiras de 1,5 x 1,5 m de área e 1,7 m de profundidade (Figura 15a), referente a cada repetição dos três tratamentos estudados. Um túnel construído a $1 \mathrm{~m}$ de profundidade era a segunda etapa de instalação do lisímetro. O túnel que possuía dimensões de 1,2 m de comprimento e $0,4 \mathrm{~m}$ de altura foi construído na parede da trincheira que estava voltada para o centro da parcela. O solo acima do túnel permanecia não revolvido (Figura 15b).
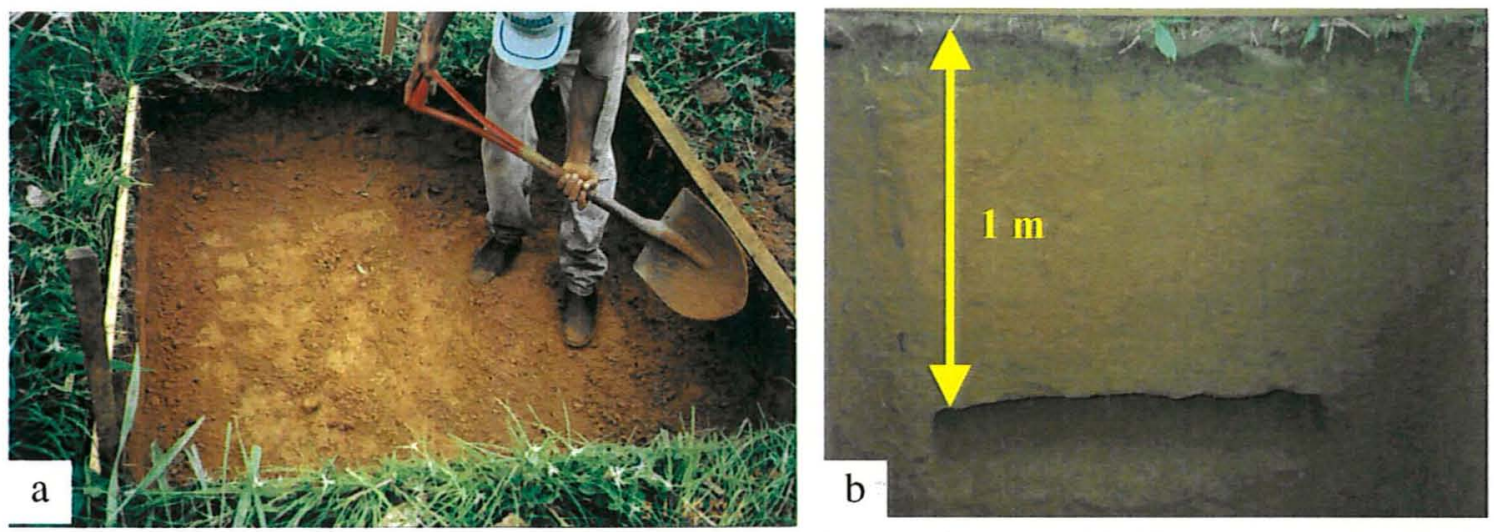

Figura 15 - Processo de instalação do lisímetro de tensão zero. (a) Construção da trincheira de 1,5 x 1,5 m e 1,7 m de profundidade (b) vista frontal do túnel construído a $1 \mathrm{~m}$ de profundidade na parede da trincheira.

Dentro do túnel era instalado o lisímetro de tensão zero. Para evitar problemas entre o fluxo da solução do solo não revolvido e o lisímetro de tensão zero, preencheu-se 
sua parte interior com areia lavada e peneirada, o que facilitava a drenagem como mostra a Figura 16(a).

O contato dos lisímetros preenchidos com areia lavada e o solo não revolvido eram realizado com caibros de madeira sustentados por solo compactado, que preencheu os espaços vagos existentes no túnel evitando assim qualquer tipo de desmoronamento (Figura 16b).
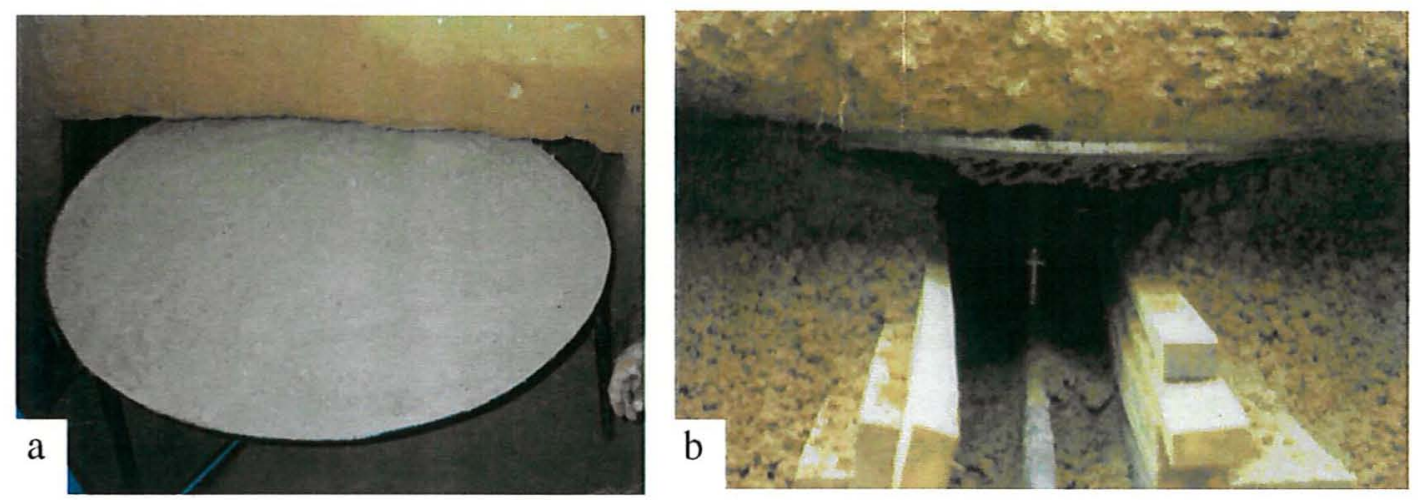

Figura 16 - Processo de instalação do lisímetro de tensão zero. (a) lisímetro de tensão zero preenchido com areia lavada; (b) lisímetro instalado no túnel do solo.

Posteriormente à instalação do lisímetro no túnel, uma parte da trincheira de 1,5 x 1,5 m foi tampada com o solo que havia sido retirado daquele local, respeitando seus horizontes. Com dimensões de 0,5 x 1,5 m a trincheira temporária após ser lacrada, era escorada com uma parede de madeira para sustentação do solo revolvido. Isso foi realizado para diminuição dos efeitos do ambiente sobre o solo que não havia sido revolvido, adquirindo assim uma solução amostrada mais próxima da real existente no solo (Figura 17a).

Sobre a fração da trincheira que não foi lacrada com solo, uma área de $1,5 \mathrm{~m}^{2} \mathrm{e}$ 1,7 $\mathrm{m}$ de profundidade, foi construída uma fossa de coleta. Nessa fossa de coleta, distante aproximadamente $0,5 \mathrm{~m}$ do lisímetro de tensão zero, foram acomodados os recipientes que funcionaram como reservatório das soluções de escoamento superficial e de solução lixiviada do solo. 
Para proteção do sistema de coleta, instalou-se sobre a fossa coletora uma cobertura móvel construída em madeira e revestida com lamina de zinco. A cobertura além de evitar a entrada de animais na fossa, evitava também que a água da chuva penetrasse nos reservatórios das soluções de escoamento superficial e da solução lixiviada do solo (Figura 17b).
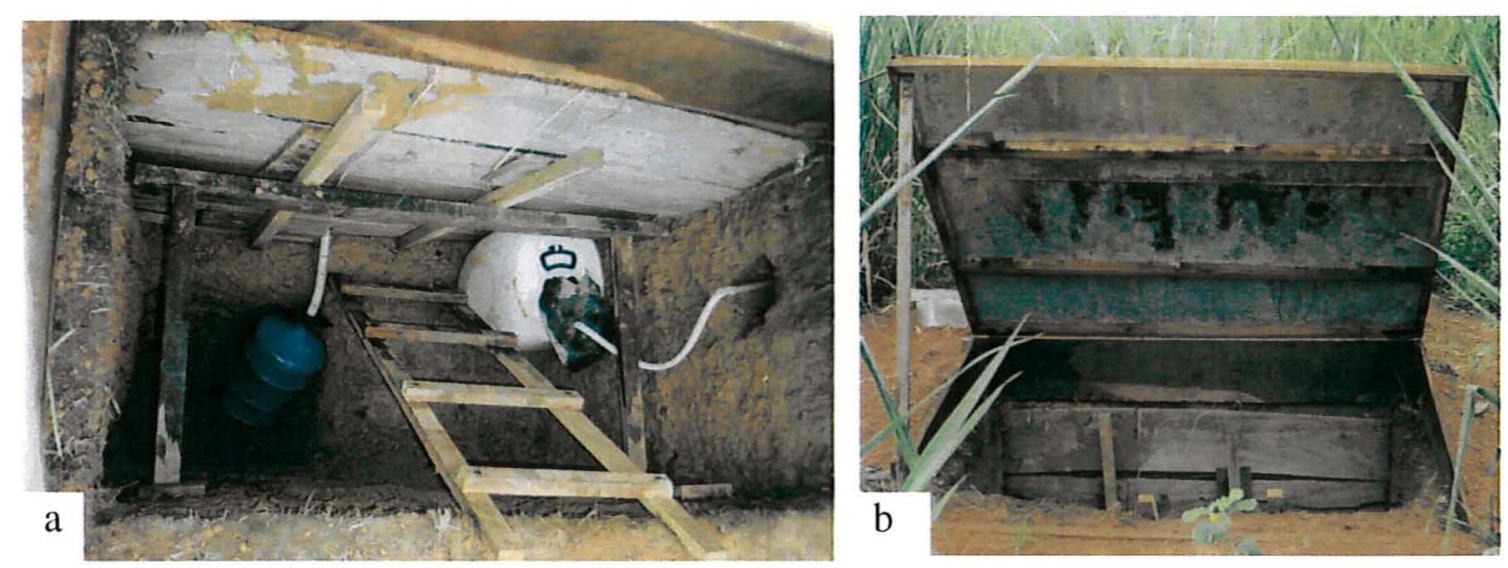

Figura 17 - Fotos da fossa de coleta. (a) fossa de coleta com a parede de madeira e os reservatórios de coleta de solução de escoamento superficial e de solução lixiviada; (b) imagem da cobertura móvel da fossa de coleta.

\subsection{Métodos Analíticos}

\subsubsection{Caracterização Química do Solo}

As amostras coletadas no campo foram secas ao ar, passadas em peneira de $2 \mathrm{~mm}$ e encaminhadas para análise química. O carbono total foi extraído por combustão a seco e determinado utilizando-se um analisador LECO CN-2000 em amostras moídas e peneiradas a 100 "meshes".

$\mathrm{O}$ pH foi medido em suspensão aquosa de $\mathrm{CaCl}_{2} 0,01 \mathrm{~mol} \mathrm{~L}^{-1}$ na proporção solo:solução de 1:2,5. 


\subsubsection{Caracterização química das soluções}

A cada coleta que se realizava no campo após o termino das precipitações ou depois de 24 horas no caso do lisímetro de tensão, as soluções obtidas eram encaminhadas para o laboratório da Fazenda Nova Vida, onde recebiam o tratamento específico de preservação para cada tipo de análise a que seriam submetidas. Após essa preservação, as amostras já separadas em seus devidos frascos eram armazenadas no refrigerador até que fossem encaminhadas aos laboratórios de Biogeoquímica do solo/CENA ou ao laboratório de ecologia isotópica/CENA.

O total de solução coletada a cada precipitação era muito variável e em algumas vezes não era suficiente para todas as analise desejadas. Dependendo da quantidade de solução obtida, as alíquotas eram separadas respeitando uma ordem de importância previamente determinada. A ordem era: i) $\mathrm{pH}$, condutividade e carbono orgânico dissolvido; ii) cátions, anions e carbono inorgânico dissolvido; iii) metais e elementos traços; iv) Nitrogênio e fósforo total dissolvidos; v) ${ }^{13} \mathrm{C}$ presente no carbono inorgânico dissolvido; vi) ${ }^{13} \mathrm{C}$ presente no carbono orgânico dissolvido.

Para cada tipo de analise, era necessário um tipo diferente de preservação da amostra e diferentes quantidades de solução, pois cada equipamento utilizado na análise suporta ou se adapta melhor aos diferentes tipos de preservantes. Toda a descrição desta rotina criada para a analise das soluções estão descritas no Anexo B.

Para a confecção dessa dissertação foram utilizados os dados de fertilidade e densidade do solo e pH, condutividade, força iônica e carbono orgânico dissolvido da solução do solo. No entanto, o restante das informações obtido com as análises químicas realizadas nas soluções coletadas, será fonte de dados para mais estudos e serão utilizados para publicação em periódicos conceituados.

\subsubsection{1 pH e Condutividade Elétrica}

Sua medição foi realizada com eletrodo de vidro para $\mathrm{pH}$ e condutivímetro para condutividade elétrica. Essa medição direta foi realizada logo após obtenção da amostra na própria fazenda (amostra fresca). 
A Condutividade Elétrica expressa a capacidade de uma solução em conduzir eletricidade e é proporcional a concentração total de eletrólitos em solução. Conseqüentemente a medida da condutividade elétrica além de fornecer condições para estimativa da concentração do total de eletrólitos, pode ser um método simples para estimativa da força iônica da solução.

\subsubsection{Força Iônica}

A Força Iônica de uma solução representa uma variável de grande valor no estudo de solução de solo. Seu valor expressa a composição da solução em termos de atividade iônica. Vários estudos foram realizados correlacionando a força iônica com a condutividade elétrica, e estes estudos mostraram que para a solução do solo a força iônica pode ser calculada a partir da condutividade elétrica dessa solução.

Para a estimativa da força iônica (FI) a partir da condutividade elétrica (CE) das soluções do solo neste trabalho, utilizou-se a equação obtida por Gillman \& Bell (1978):

$$
\mathrm{FI}=0,0109 \mathrm{CE}-0,0002
$$

Para obtenção dessa equação os autores trabalharam com solução de seis solos tropicais e com métodos de coletas semelhantes aos utilizados nesse estudo. É importante ressaltar que para uso da equação, a condutividade elétrica deve estar expressa em dS para que o resultado da força iônica seja expressa em $\mathrm{mol} \mathrm{L}^{-1}$.

\subsubsection{Carbono Orgânico Dissolvido}

As amostras encaminhadas para análise de carbono orgânico dissolvido, eram filtradas em filtros de microfibra de vidro $\mathrm{GF} / \mathrm{F}$ de $0,7 \mu \mathrm{m}$, previamente calcinado a $500{ }^{\circ} \mathrm{C}$ por 5 horas. Após a filtragem as alíquotas eram armazenadas em frascos de cintilação, também previamente calcinados e preservada com $\mathrm{HgCl}_{2}\left(30 \mathrm{mmol} \mathrm{L}^{-1}\right)$ para evitar o crescimento de microorganismos que pudessem alterar a concentração inicial do carbono orgânico dissolvido na solução.

As tampas dos frascos para armazenagem das soluções de carbono orgânico dissolvido eram lavadas com água deionizadas. As tampinhas de teflon (Teflon cap), 
utilizadas para evitar o contato da tampa do frasco com a solução filtrada, eram preparadas para o uso com saturação em solução de $\mathrm{HCl} 10$ \% por uma hora e lavagem posterior com água ultrapura.

As determinações do carbono orgânico dissolvido foram realizadas em um auto analisador Shimadzu TOC-5000. O método analítico consiste em uma pré-acidificação, com ácido clorídrico para transformação do carbono inorgânico em $\mathrm{CO}_{2}$. Com a liberação do $\mathrm{CO}_{2}$ a amostra é guiada até um detector de infravermelho, determinando assim a concentração total de carbono que representa o teor de carbono orgânico dissolvido.

\subsection{Análise Estatística dos resultados}

Os resultados obtidos no delineamento experimental de blocos casualizados foram submetidos à análise de variância (teste F), empregando o procedimento GLM do programa de análise estatística SAS (SAS Institute, 1987). Realizou-se a comparação das médias entre tratamentos e entre os meses pelo teste de Duncan a $5 \%$. 


\section{RESULTADOS E DISCUSSÃO}

\subsection{Características da água da chuva}

O período de janeiro a maio do ano de 2002 foi marcado por uma quantidade reduzida de precipitação em relação à média referente ao mesmo período dos anos de 1993 a 2000 (Figura 17). Embora, seja comum na região Amazônica uma variação na quantidade de chuva (Salati \& Marques, 1986), nos últimos sete anos nunca houve uma pluviosidade tão baixa no período de janeiro a maio, como o ocorrido no ano de 2002.

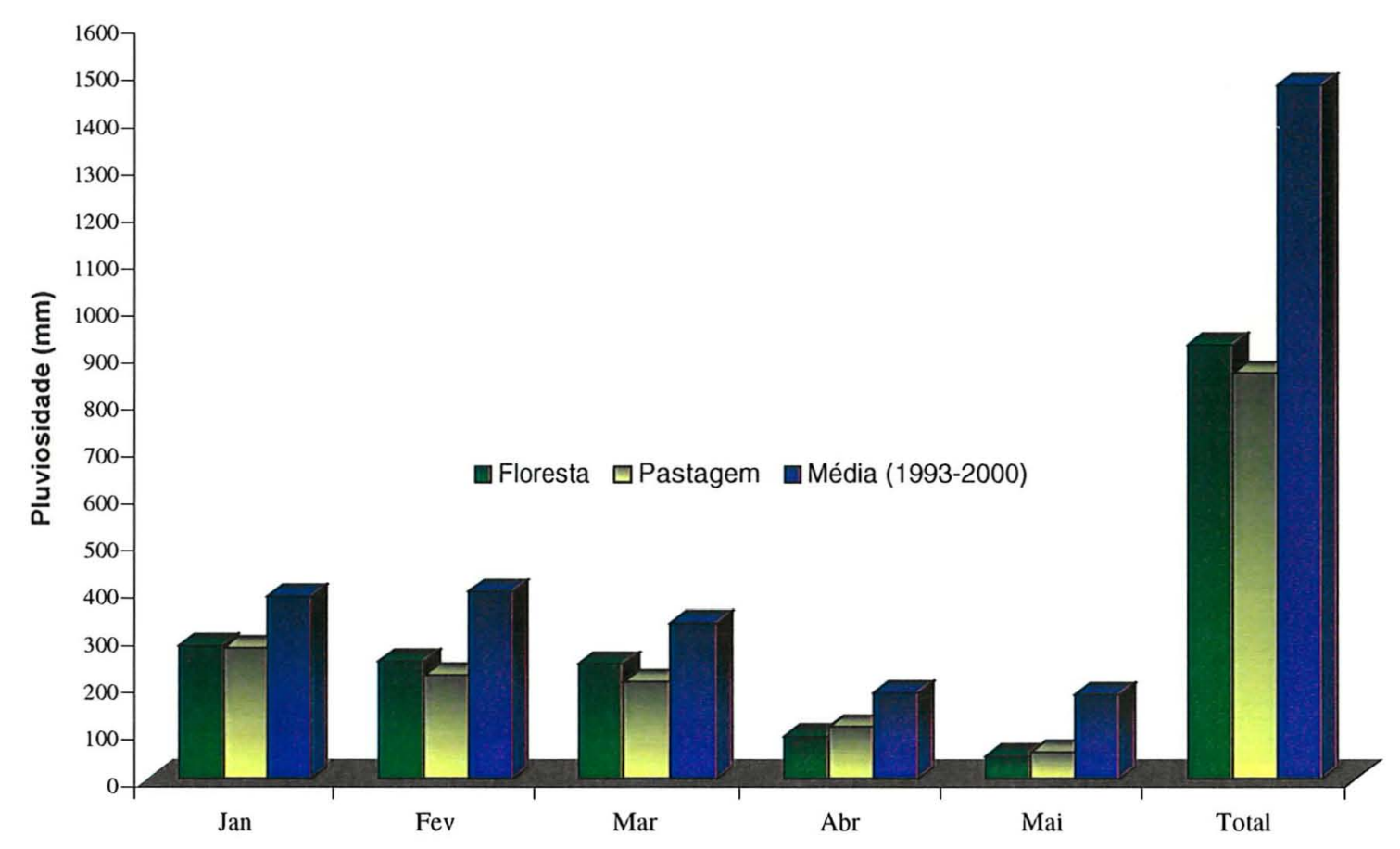

Figura 17 - Quantidade de chuva no período de janeiro a maio de 2002 e suas médias referentes aos anos de 1993 a 2000. 
O gráfico da figura 17 também demonstra uma pequena diferença entre a quantidade de chuva amostrada na área experimental sob pastagem e na área experimental sob floresta, sendo que essa última apresentou uma quantidade maior de chuva no período amostrado.

A Tabela 5 ilustra algumas características químicas da água da chuva, coletada e analisada nesse experimento. No geral, a chuva apresentou um meio ligeiramente ácido $(\mathrm{pH}=6,07)$, Esse valor difere bastante de estudos realizados na Alemanha onde a água da chuva é bem mais ácida (Meiwes et al., 1998). A condutividade elétrica e a força iônica da água da chuva apresentaram algumas variações entre os meses analisados: os meses de fevereiro e março apresentaram os menores e os maiores valores respectivamente para esses dois paramentos.

Uma das grandes surpresas desse trabalho foi à concentração de carbono orgânico dissolvido (COD) na água da chuva. Nota-se um teor relativamente elevado e que segue uma tendência de aumento conforme os meses apresentavam uma menor quantidade de chuva. Supõem-se que por esse local de coleta encontrar-se nas proximidades de uma floresta a volatilização de gases orgânicos seja alta, contribuindo assim para o aumento da concentração de COD na água da chuva, ficando mais concentrado na atmosfera com a menor taxa de precipitação.

Tabela 5. Valores de pH, força iônica (FI), condutividade elétrica (CE) e carbono orgânico dissolvido (COD) da água da chuva.

\begin{tabular}{lcccc}
\hline \multicolumn{1}{c}{ Mês } & $\mathrm{pH}$ & $\mathrm{FI}$ & $\mathrm{CE}$ & $\mathrm{COD}$ \\
\hline & & $\mathrm{mol}_{\mathrm{c}} \mathrm{L}^{-1}$ & $\mu \mathrm{S}$ & $\mathrm{mg} \mathrm{dm}^{-3}$ \\
Janeiro & 5,42 & 0,176 & 161,68 & 3,05 \\
Fevereiro & 6,15 & 0,010 & 9,47 & 2,05 \\
Março & 6,51 & 0,133 & 142,83 & 3,56 \\
Abril & 5,93 & 0,093 & 85,67 & 5,38 \\
Maio & 6,38 & 0,097 & 89,4 & 6,23 \\
Média & 6,07 & 0,102 & 97,81 & 4,05 \\
\hline
\end{tabular}


A partir da concentração de COD e da quantidade de chuva no período, calculouse a participação da chuva como fornecedora de carbono orgânico para o solo (Tabela 6). Devido à alta concentração de COD a participação da chuva é muito significante no ciclo do carbono nessa região, fornecendo para o sistema florestal $30,21 \mathrm{~kg} \mathrm{ha}^{-1}$ e $29,17 \mathrm{~kg} \mathrm{ha}^{-1}$ na área experimental sob pastagem. Essa pequena diferença entre a área sob floresta e a área sob pastagem esta relacionada as diferentes quantidades de chuva nestes dois sistemas. Nota-se que apesar da reduzida quantidade de chuva nos meses de abril e maio, a elevada concentração de COD (Tabela 5), garante a esses dois meses uma participação expressiva no total de COD fornecido pela água da chuva,

Tabela 6. Chuva total e entrada total de carbono (C) pela chuva por $\mathrm{m}^{2}$.

\begin{tabular}{lcccc}
\hline \multirow{2}{*}{ Mês } & \multicolumn{2}{c}{ Floresta } & \multicolumn{2}{c}{ Pastagem } \\
\cline { 2 - 5 } & Chuva total & Entrada de C & Chuva total & Entrada de C \\
\hline \multirow{2}{*}{ Janeiro } & $\mathrm{mm}$ & $\mathrm{mg} \mathrm{m}^{-2}$ & $\mathrm{~mm}$ & $\mathrm{mg} \mathrm{m}^{-2}$ \\
Fevereiro & 282,7 & 862,23 & 277,4 & 846,07 \\
Março & 248,8 & 510,04 & 219,4 & 449,77 \\
Abril & 243,8 & 867,92 & 206,3 & 734,60 \\
Maio & 89,9 & 435,11 & 109,5 & 589,11 \\
Total & 55,6 & 346,38 & 47,9 & 298,41 \\
& 920,8 & 3021,68 & 860,5 & 2917,96 \\
\hline
\end{tabular}

\subsection{Características do pluviolixiviado}

A composição da solução de pluviolixiviado depende inicialmente do estado nutricional e da fase do ciclo em que se encontra a planta (Mahendrappa, 1986). A solução de pluviolixiviado coletada na floresta apresentou uma força iônica e condutividade elétrica duas vezes superior a da água da chuva, indicando uma quantidade maior de eletrólitos na solução de pluviolixiviado, ou seja, uma concentração de elementos disssolvidos nessa solução maior que na água da chuva. Em contrapartida, a força iônica e a condutividade 
elétrica da solução de pluviolixiviado variaram de acordo com a quantidade de chuva em cada mês, sendo que quanto maior era a quantidade de chuva, menor era a força iônica e a condutividade dessa solução (Tabela 7).

A concentração de COD (aproximadamente duas vezes maior que na água da chuva) e o pH mais elevado dessa solução tendem para uma composição química mais complexa dessa solução quando comparada à água da chuva. A presença de compostos orgânicos e íons livres que se ligam ao hidrogênio podem elevar o pH da solução. Meiwes et al. (1998), constataram que aumentos de $\mathrm{Ca}^{+2}$ e $\mathrm{K}^{+}$na concentração de souluções de pluviolixiviado causaram reduções nos teores de $\mathrm{H}^{+}$e conseqüentemente elevação do $\mathrm{pH} . \mathrm{A}$ concentração mais elevada de COD, é devido principalmente a liberação de compostos orgânicos solúveis de baixo peso molecular pela copa da floresta.

Tabela 7. Valores de pH, força iônica (FI), condutividade elétrica (CE) e carbono orgânico dissolvido (COD) do pluviolixiviado.

\begin{tabular}{lcccc}
\hline \multicolumn{1}{c}{ Mês } & $\mathrm{pH}$ & $\mathrm{FI}$ & $\mathrm{CE}$ & $\mathrm{COD}$ \\
\hline \multirow{2}{*}{ Janeiro } & & mol $_{\mathrm{c}} \mathrm{L}^{-1}$ & $\mu \mathrm{S}$ & $\mathrm{mg} \mathrm{L}^{-1}$ \\
Fevereiro & 6,43 & 0,034 & 31,85 & 11.05 \\
Março & 6,37 & 0,030 & 28,44 & 10,60 \\
Abril & 6,80 & 0,173 & 159,04 & 6,65 \\
Maio & 6,34 & 0,690 & 633,55 & 6,17 \\
Média do período & 6,13 & 0,345 & 317,00 & 8,94 \\
\hline
\end{tabular}

A exemplo da água da chuva, calculou-se também a entrada de COD dessa solução, permitindo assim mostrar toda a participação de cada processo no ciclo do carbono discutido a seguir no item de balanço do COD. Apesar da precipitação interna da floresta (pluviolixiviado) ter sido de $587 \mathrm{~mm}$ (Tabela 8), cerca de $63 \%$ da quantidade total da chuva registrada na área da floresta no período, a grande concentração de COD dessa solução, proporcionou uma entrada de carbono no sistema de $52,77 \mathrm{~kg} \mathrm{ha}^{-1}$. Sabendo que a água da chuva pode contribuir com $30,21 \mathrm{~kg} \mathrm{de} \mathrm{Cha}^{-1}$ e que o pluviolixiviado pode gerar 
acréscimos no sistema florestal de $52,77 \mathrm{~kg} \mathrm{de} \mathrm{C} \mathrm{ha}^{-1}$, pode-se deduzir que a liberação de COD pela copa da floresta foi de $22,56 \mathrm{~kg} \mathrm{de} \mathrm{C} \mathrm{ha}^{-1}$ no período de janeiro a maio de 2002 .

Tabela 8. Volume e entrada totais de carbono (C) pela solução de pluviolixiviado por $\mathrm{m}^{2}$.

\begin{tabular}{lcc}
\hline \multicolumn{1}{c}{ Mês } & Volume total & Entrada de C \\
\hline & $\mathrm{L} \mathrm{m}^{2}$ & $\mathrm{mg} \mathrm{m}^{2}$ \\
Janeiro & 162,4 & 1794,52 \\
Fevereiro & 160,5 & 1701,30 \\
Março & 178,1 & 1184,36 \\
Abril & 64,4 & 397,34 \\
Maio & 22,37 & 199,98 \\
Total & 587,77 & 5277,50 \\
\hline
\end{tabular}

\subsection{Composição química da solução de escoamento superficial}

A Tabela 9 mostra os valores médios sobre o volume e características químicas da solução de escoamento superficial durante o período de janeiro a maio de 2002 , nas áreas sob floresta, controle e pastagem gradeada. $O$ volume de solução coletado por escoamento superficial na floresta é bastante reduzido, se comparado aos dois tratamentos de pastagem, provavelmente devido a quantidade de solução que fica retida na copa da floresta, cerca de $37 \%$ da quantidade total de chuvas.

Considerando os dois tratamentos de pastagem, o volume de solução no tratamento controle foi maior que no tratamento de gradagem. Com a gradagem, ocorre uma quebra na camada compactada da superficie do solo, causada pelo pastejo. Essa técnica muito utilizada no plantio convencional, apesar de gerar vários efeitos negativos em relação a matéria orgânica do solo, estrutura do solo, compactação subsuperficial, entre outros parâmetros, também aumenta a infiltração de água no solo na camada superficial, o que diminui a quantidade de escoamento superficial. A força iônica e a condutividade da solução nos três tratamentos não apresentaram diferenças significativas. 
$\mathrm{O}$ pH da solução de escoamento superficial (Tabela 9) mostra que a solução coletada em solo florestal é mais ácida do que a solução obtida sob pastagem. Esse fato se deve principalmente a quantidade e composição mais enriquecida da liteira existente sobre o solo da floresta, a qual possui provavelmente uma maior quantidade de ácidos orgânicos, como, alias, confirma a análise de carbono orgânico dissolvido na solução, que é bem maior na floresta. A análise estatística da força iônica e da condutividade elétrica da solução de escoamento superficial mostrou não haver diferença significativa entre os tratamentos.

Tabela 9. Volume, $\mathbf{p H}$, força iônica (FI), condutividade elétrica (CE) e carbono orgânico dissolvido (COD) da solução de escoamento superficial durante o período de janeiro a maio de 2002 , nas áreas sob floresta, controle e pastagem gradeada.

\begin{tabular}{lccccc}
\hline Tratamento & Volume & $\mathrm{pH}$ & $\mathrm{FI}$ & $\mathrm{CE}$ & $\mathrm{COD}$ \\
\hline \multirow{2}{*}{ Floresta } & $\mathrm{mL}$ & & $\mathrm{mol}_{\mathrm{c}} \mathrm{L}^{-1}$ & $\mu \mathrm{S}$ & $\mathrm{mg} \mathrm{\textrm {L } ^ { - 1 }}$ \\
Controle & $24.818 \mathrm{a}$ & $6,22 \mathrm{~b}$ & $0,345 \mathrm{a}$ & $317,14 \mathrm{a}$ & $13,13 \mathrm{a}$ \\
Gradagem & $17.070 \mathrm{~b}$ & $6,49 \mathrm{a}$ & $0,300 \mathrm{a}$ & $275,91 \mathrm{a}$ & $11,11 \mathrm{~b}$ \\
$\mathrm{CV}$ & 60,90 & 5,80 & 75,90 & 75,85 & 56,86 \\
\hline
\end{tabular}

A solução de escoamento superficial foi a que proporcionou as maiores saídas do carbono orgânico dissolvido do sistema. O volume total obtido na floresta foi bem inferior ao volume obtido na pastagem, o que proporciona uma saída de carbono no sistema de pastagem bem mais elevado que na floresta. $O$ tratamento controle apresentou as maiores perdas, $1678 \mathrm{mg} \mathrm{C} \mathrm{m}^{-2}$, enquanto que a pastagem gradeada perdeu $1083 \mathrm{mg} \mathrm{C} \mathrm{m}^{-2}$, e a floresta apenas $172 \mathrm{mg} \mathrm{C} \mathrm{m}^{-2}$ (Tabela 10) 
Tabela 10. Volume e saída totais de carbono (C) pela solução de escoamento superficial por $\mathrm{m}^{2}$.

\begin{tabular}{|c|c|c|c|c|c|c|}
\hline \multirow{2}{*}{ Mês } & \multicolumn{3}{|c|}{ Volume total } & \multicolumn{3}{|c|}{ Saída de C } \\
\hline & Floresta & Pastagem & Gradagem & Floresta & Pastagem & Gradagem \\
\hline & \multicolumn{3}{|c|}{$-\mathrm{L} \mathrm{m} \mathrm{m}^{2}$} & \multicolumn{3}{|c|}{ - } \\
\hline Janeiro & 3,39 & 16,6 & 15,39 & 72,75 & 184,59 & 130,66 \\
\hline Fevereiro & 1,17 & 42,75 & 32,1 & 19,81 & 541,64 & 266,11 \\
\hline Março & 5,21 & 57,23 & 37,29 & 55,17 & 657,52 & 315,47 \\
\hline Abril & 2,04 & 21,60 & 17,11 & 17,99 & 246,89 & 256,00 \\
\hline Maio & 0,87 & 6,46 & 7,51 & 6,83 & 48,19 & 115,47 \\
\hline Total & 12,68 & 144,64 & 109,40 & 172,54 & 1678,83 & 1083,72 \\
\hline
\end{tabular}

\subsection{Composição química da solução do solo}

A solução do solo coletada por lisímetros de tensão, não permite cálculos da quantidade de carbono orgânico dissolvido em uma certa área, pois com esse tipo de coletor não se conhece sua zona de influencia.

A Tabela 11, mostra os resultados médios da análise da solução do solo no período de estudo. O volume da solução coletado nos lisímetros só é diferente estatisticamente no tratamento de pastagem gradeada. Isto pode ser explicado pela maior quantidade de água que cai sobre o solo em relação a floresta, e a maior infiltração em relação a pastagem controle. Uma possível compactação subsuperficial pode diminuir a infiltração a camadas mais profundas e assim aumentar a quantidade de solução coletada pelo lisímetro, apresentando maior quantidade de solução a um metro de profundidade.

O valor de pH dessa solução, a exemplo do escoamento superficial, foi inferior, para a solução coletada na floresta do que na pastagem. A solução do solo sob floresta também apresentou força iônica e condutividade elétrica mais elevada do que o solo sob pastagem.

Quanto a concentração de carbono orgânico dissolvido nessa solução só houve diferença significativa entre os tratamentos de pastagem gradeada, com a concentração de 
$4,87 \mathrm{mg} \mathrm{L}^{-1}$, e a pastagem controle com 3,63 $\mathrm{mg} \mathrm{L}^{-1}$. Apesar das concentrações de COD serem baixas, muitos estudos mostram que a concentração de COD diminui bruscamente com o aumento da profundidade do solo (McDowell \& Wood, 1984), o que indica que esse solo em camadas mais próximas a superficie apresenta-se em altas concentrações.

Tabela 11. Médias de volume, $\mathrm{pH}$, força iônica (FI), condutividade elétrica (CE) e carbono orgânico dissolvido (COD) na solução do solo coletado por lisímetro de tensão.

\begin{tabular}{lccccc}
\hline Tratamento & Volume & $\mathrm{pH}$ & FI & $\mathrm{CE}$ & COD \\
\hline \multirow{2}{*}{ Floresta } & $\mathrm{mL}$ & & mol $_{\mathrm{c}} \mathrm{L}^{-1}$ & $\mu \mathrm{S}$ & $\mathrm{mg} \mathrm{L}^{-1}$ \\
Controle & $199 \mathrm{~b}$ & $6,49 \mathrm{~b}$ & $0,408 \mathrm{a}$ & $374,87 \mathrm{a}$ & $4,09 \mathrm{ab}$ \\
Gradagem & $352 \mathrm{~b}$ & $6,70 \mathrm{a}$ & $0,235 \mathrm{~b}$ & $216,46 \mathrm{~b}$ & $3,63 \mathrm{~b}$ \\
CV & 49,13 & $6,68 \mathrm{a}$ & $0,291 \mathrm{~b}$ & $267,5 \mathrm{~b}$ & $4,87 \mathrm{a}$ \\
\hline
\end{tabular}

\subsection{Composição química da solução lixiviada}

A quantidade de solução coletada a um metro de profundidade foi menor que a esperada no início do estudo. A pequena quantidade de chuva do período no ano de 2002 quando comparado à média de 7 anos, foi a principal causa da pequena quantidade de solução lixiviada amostrada.

$O$ volume médio de solução lixiviada foi maior para o tratamento de pastagem controle e menor na floresta. A solução lixiviada no tratamento sob pastagem gradeada apresentou um $\mathrm{pH}$ mais elevado do que os tratamentos da floresta e da pastagem controle (Tabela 12). A concentração de carbono orgânico dissolvido na solução foi maior no tratamento de pastagem gradeada, seguido pela pastagem controle e pela floresta. Esse fato, confirma o equilíbrio existente no sistema florestal. 
Tabela 12. Médias de volume, $\mathrm{pH}$, força iônica (FI), condutividade elétrica (CE) e carbono orgânico dissolvido (COD) na solução lixiviada do solo.

\begin{tabular}{lccccc}
\hline Tratamento & Volume & $\mathrm{pH}$ & $\mathrm{FI}$ & $\mathrm{CE}$ & $\mathrm{COD}$ \\
\hline \multirow{2}{*}{ Floresta } & $\mathrm{mL}$ & & $\mathrm{mol}_{\mathrm{c}} \mathrm{L}^{-1}$ & $\mu \mathrm{S}$ & $\mathrm{mg} \mathrm{L}^{-1}$ \\
Controle & $670 \mathrm{c}$ & $5,17 \mathrm{~b}$ & $0,103 \mathrm{a}$ & $94,80 \mathrm{a}$ & $1,69 \mathrm{c}$ \\
Gradagem & $4442 \mathrm{a}$ & $5,55 \mathrm{~b}$ & $0,084 \mathrm{a}$ & $77,38 \mathrm{a}$ & $2,49 \mathrm{~b}$ \\
$\mathrm{CV}$ & $1969 \mathrm{~b}$ & $6,45 \mathrm{a}$ & $0,161 \mathrm{a}$ & $148,46 \mathrm{a}$ & $6,37 \mathrm{a}$ \\
& 44,46 & 8,89 & 83,07 & 82,93 & 19,14 \\
\hline
\end{tabular}

A quantidade de carbono que lixiviou a 1 metro de profundidade retirou uma quantidade mais elevada de carbono do tratamento de pastagem gradeada (Tabela 13). Apesar do volume total de solução obtida na pastagem controle ser duas vezes maior que na pastagem gradeada, a concentração mais elevada de carbono orgânico dissolvido na solução lixiviada acaba elevando as perdas totais por lixiviação nesse tratamento para $106 \mathrm{mg} \mathrm{C} \mathrm{m}^{-2}$ contra 7,34 e $85 \mathrm{mg} \mathrm{C} \mathrm{m}^{-2}$ da floresta e pastagem controle, respectivamente.

Tabela 13. Volume e saidas totais de carbono (C) lixiviados do solo por $\mathrm{m}^{2}$.

\begin{tabular}{|c|c|c|c|c|c|c|}
\hline \multirow{2}{*}{ Dia } & \multicolumn{3}{|c|}{ Volume total } & \multicolumn{3}{|c|}{ Saída de C } \\
\hline & Floresta & Pastagem & Gradagem & Floresta & Pastagem & Gradagem \\
\hline & \multicolumn{3}{|c|}{-..--L m ${ }^{2}$} & \multicolumn{3}{|c|}{--ng m ${ }^{2}$} \\
\hline 28 / Janeiro & 0,92 & 1,37 & 0,30 & 1,88 & 1,72 & 2,18 \\
\hline $30 /$ Janeiro & $\mathrm{Nd}$ & 1,31 & 1,40 & nd & 2,89 & 6,32 \\
\hline 18 / Fevereiro & 0,83 & 1,98 & 1,16 & 1,06 & 7,82 & 10,06 \\
\hline 01 / Março & 0,62 & 1,80 & 6,68 & 1,01 & 4,31 & 40,33 \\
\hline 09 / Março & 1,38 & 25,33 & 4,90 & 2,31 & 62,82 & 40,92 \\
\hline 12 / Março & 0,66 & 2,07 & 1,89 & 1,08 & 5,47 & 6,42 \\
\hline Total & 4,41 & 33,86 & 16,33 & 7,34 & 85,03 & 106,23 \\
\hline
\end{tabular}

d = Não determinado 


\subsection{Estoque do carbono orgânico e pH do solo}

As características do solo até a profundidade de $30 \mathrm{~cm}$ nas áreas sob floresta, pastagem controle e gradeada estão descritos nas tabelas 14, 15 e 16 respectivamente. Os solos dos três sistemas estudados apresentam uma redução no $\mathrm{pH}$ em função da profundidade. O solo sob floresta foi o que apresentou os menores valores de $\mathrm{pH}$, que provavelmente refletiu, como já discutido, na solução que estava em seu contato buscando o equilíbrio com o mesmo. A porcentagem de carbono no solo, a exemplo do $\mathrm{pH}$, também diminuiu conforme aumentava a profundidade do solo.

A densidade do solo sob floresta, apresentou uma compactação que a pastagem nos primeiros $5 \mathrm{~cm}$ de profundidade e sempre foi menor que a densidade da pastagem controle. A pastagem gradeada, apresentou uma densidade menor que a floresta na camada de 5 a $10 \mathrm{~cm}$, isso devido a gradagem realizada nesse solo.

O cálculo do estoque de carbono na camada de zero a trinta centímetros de profundidade, mostrou que o solo sob pastagem possui mais carbono que a floresta. A floresta estoca na camada de 0 a $30 \mathrm{~cm}$ uma quantidade de $3,74 \mathrm{~kg} \mathrm{~m}^{-3}$, enquanto que os solos sob a pastagem controle e sob a pastagem gradeada apresentaram as quantidades de 4,56 e $4,41 \mathrm{~kg} \mathrm{~m}^{-3}$. Isso é explicado pelo fato da pastagem possuir um quantidade mais elevada de raízes que a floresta, além de possuir matéria orgânica remanescente da floresta (Bernoux et al., 1999).

Tabela 14. Valores de $\mathrm{pH}\left(\mathrm{CaCl}_{2}\right)$, teor de carbono, densidade e estoque de carbono no solo sob floresta.

\begin{tabular}{ccccc}
\hline Profundidade & $\mathrm{pH}$ & Carbono & Densidade & Estoque de Carbono \\
\hline $\mathrm{cm}$ & $\mathrm{CaCl}_{2}$ & $\%$ & $\mathrm{~g} \mathrm{~cm}^{-3}$ & $\mathrm{~kg} \mathrm{~m}^{-3}$ \\
$0-5$ & 4,42 & 1,39 & 1,19 & 0,824 \\
$5-10$ & 4,08 & 0,90 & 1,43 & 0,640 \\
$10-20$ & 3,84 & 0,79 & 1,55 & 1,223 \\
$20-30$ & 3,83 & 0,64 & 1,66 & 1,055 \\
\hline
\end{tabular}


Tabela 15. Valores de $\mathrm{pH}\left(\mathrm{CaCl}_{2}\right)$, teor de carbono, densidade e estoque de carbono no solo sob pastagem controle.

\begin{tabular}{ccccc}
\hline Profundidade & $\mathrm{pH}$ & Carbono & Densidade & Estoque de Carbono \\
\hline $\mathrm{cm}$ & & $\%$ & $\mathrm{~g} \mathrm{~cm}^{-3}$ & $\mathrm{~kg} \mathrm{~m}^{-3}$ \\
$0-5$ & 5,00 & 1,90 & 1,40 & 1,329 \\
$5-10$ & 4,76 & 1,23 & 1,64 & 1,011 \\
$10-20$ & 4,66 & 0,79 & 1,65 & 1,300 \\
$20-30$ & 4,48 & 0,56 & 1,66 & 0,923 \\
\hline
\end{tabular}

Tabela 16. Valores de $\mathrm{pH}\left(\mathrm{CaCl}_{2}\right)$, teor de carbono, densidade e estoque de carbono no solo sob pastagem gradeada

\begin{tabular}{ccccc}
\hline Profundidade & $\mathrm{pH}$ & Carbono & Densidade & Estoque de Carbono \\
\hline $\mathrm{cm}$ & $\mathrm{CaCl}_{2}$ & $\%$ & $\mathrm{~g} \mathrm{~cm}^{-3}$ & $\mathrm{~kg} \mathrm{~m}^{-3}$ \\
$0-5$ & 4,77 & 1,45 & 1,24 & 0,897 \\
$5-10$ & 4,73 & 1,36 & 1,35 & 0,915 \\
$10-20$ & 4,70 & 0,93 & 1,61 & 1,488 \\
$20-30$ & 4,66 & 0,70 & 1,59 & 1,118 \\
\hline
\end{tabular}

\subsection{Estimativa do fluxo de carbono dissolvido no solo}

\subsubsection{Floresta}

A Figura 18 é um esquema simplificado do fluxo do carbono orgânico dissolvido na solução do solo sobre floresta. Nota-se que as entradas de carbono orgânico dissolvido no sistema pela chuva e pelo pluviolixiviado, são bem maiores que as perdas pelo escoamento superficial e lixiviação, permanecendo uma concentração elevada de carbono na solução do solo. 


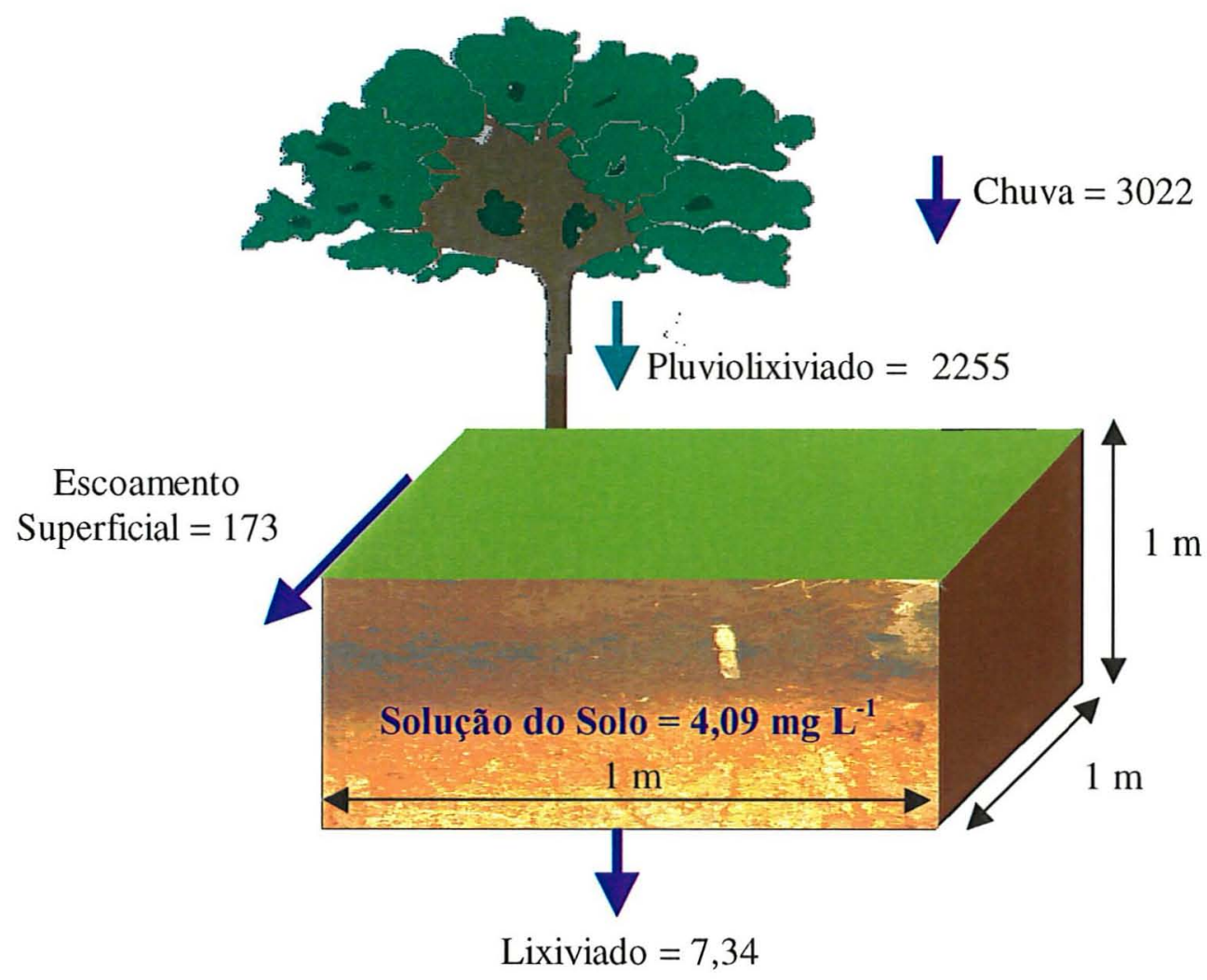

Figura 18 - Esquema do fluxo de carbono orgânico dissolvido com suas respectivas concentrações $\left(\mathrm{mg} \mathrm{C} \mathrm{m}^{-2}\right)$ na área sob floresta.

Para o sistema florestal as entradas devem ser calculadas pela soma do teor de carbono orgânico dissolvido do pluviolixiviado e da chuva, ou seja, a quantidade total de carbono orgânico dissolvido que entra no sistema é de $5277 \mathrm{mg} \mathrm{C} \mathrm{m}^{-2}$, enquanto que a quantidade total de perdas são de $180 \mathrm{mg} \mathrm{C} \mathrm{m}^{-2}$, obtidas pela soma da quantidade perdida por escoamento superficial e por lixiviação.

Esses resultados indicam que no sistema florestal, no período de janeiro a maio ocorre um acréscimo de aproximadamente $5100 \mathrm{mg} \mathrm{C} \mathrm{m}^{-2}$ de carbono orgânico dissolvido. As perdas de carbono orgânico dissolvido por lixiviação pela floresta são quantidades irrisórias, já que sta se encontra em equilíbrio, esse resultado é confirmado pelo trabalho de Manhendrappa \& Salonius (1982). 


\subsubsection{Pastagem controle}

A Figura 19 é um esquema resumido do fluxo do carbono orgânico dissolvido na solução do solo sobre a pastagem controle. Ao contrário do sistema florestal, a pastagem controle apresenta apenas a chuva como fornecedora direta de carbono orgânico dissolvido, e apresenta perdas elevadas principalmente na forma de escoamento superficial. O total de carbono orgânico dissolvido que entra nesse sistema é de $2917 \mathrm{mg} \mathrm{C} \mathrm{m}^{-2}$, enquanto que suas saídas são de $1764 \mathrm{mg} \mathrm{C} \mathrm{m}^{-2}$.

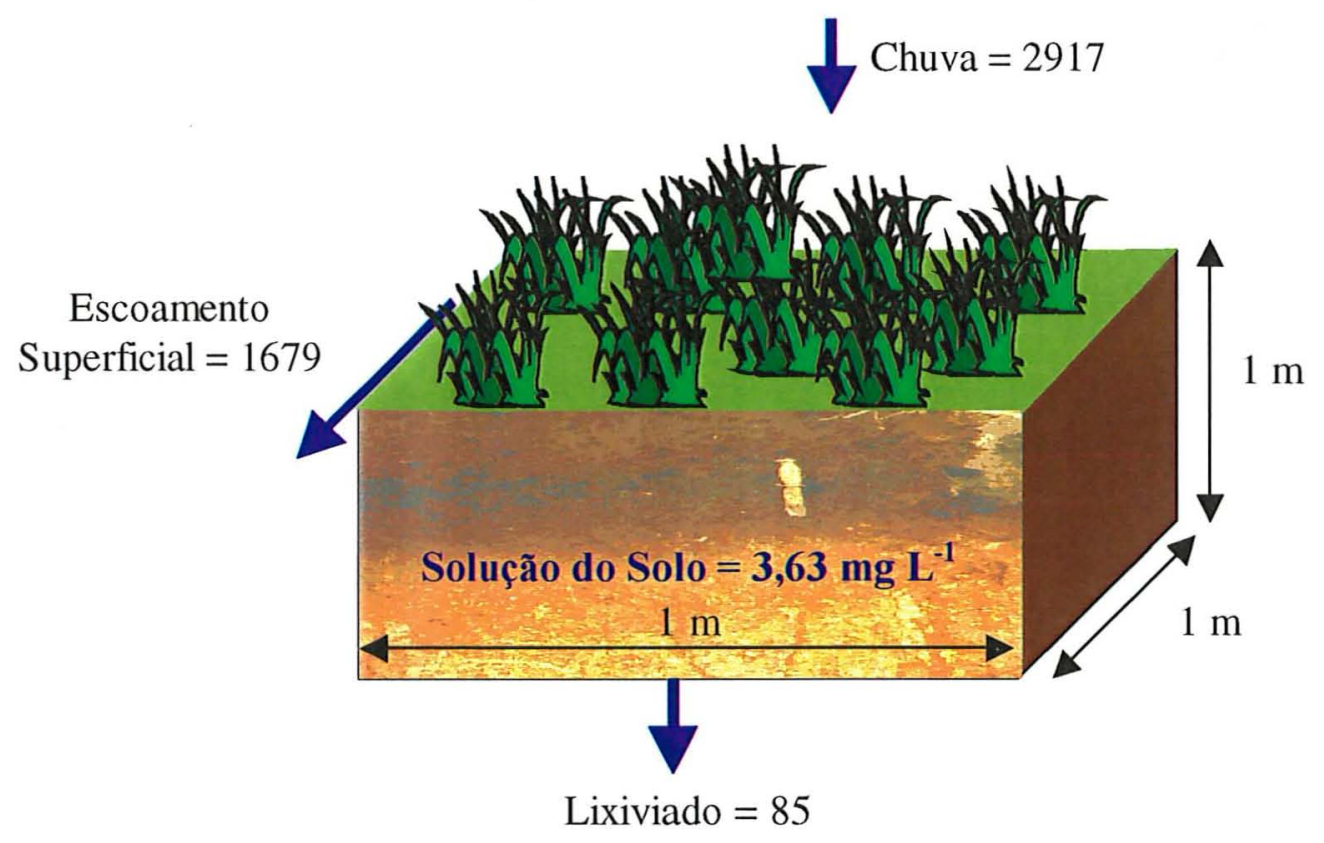

Figura 19 - Esquema do fluxo de carbono orgânico dissolvido com suas respectivas concentrações $\left(\mathrm{mg} \mathrm{C} \mathrm{m}^{-2}\right)$ na área sob pastagem controle.

Apesar da entrada ser maior do que as perdas de carbono orgânico dissolvido no sistema de pastagem, o acréscimo no período diminuiu aproximadamente cinco vezes, 1153 mg C m${ }^{-2}$, quando comparado ao sistema florestal (5100 $\mathrm{mg} \mathrm{m}^{-2}$ ). É importante ressaltar ainda que a concentração de carbono orgânico na solução do solo também foi que a concentração na solução de solo sob floresta. 


\subsubsection{Pastagem gradeada}

A Figura 20 é um esquema simplificado do fluxo do carbono orgânico dissolvido na solução do solo sobre a pastagem gradeada. Como a pastagem gradeada promoveu modificações na estrutura do solo em relação à pastagem controle, as concentrações de carbono orgânico dissolvido também foram diferentes.

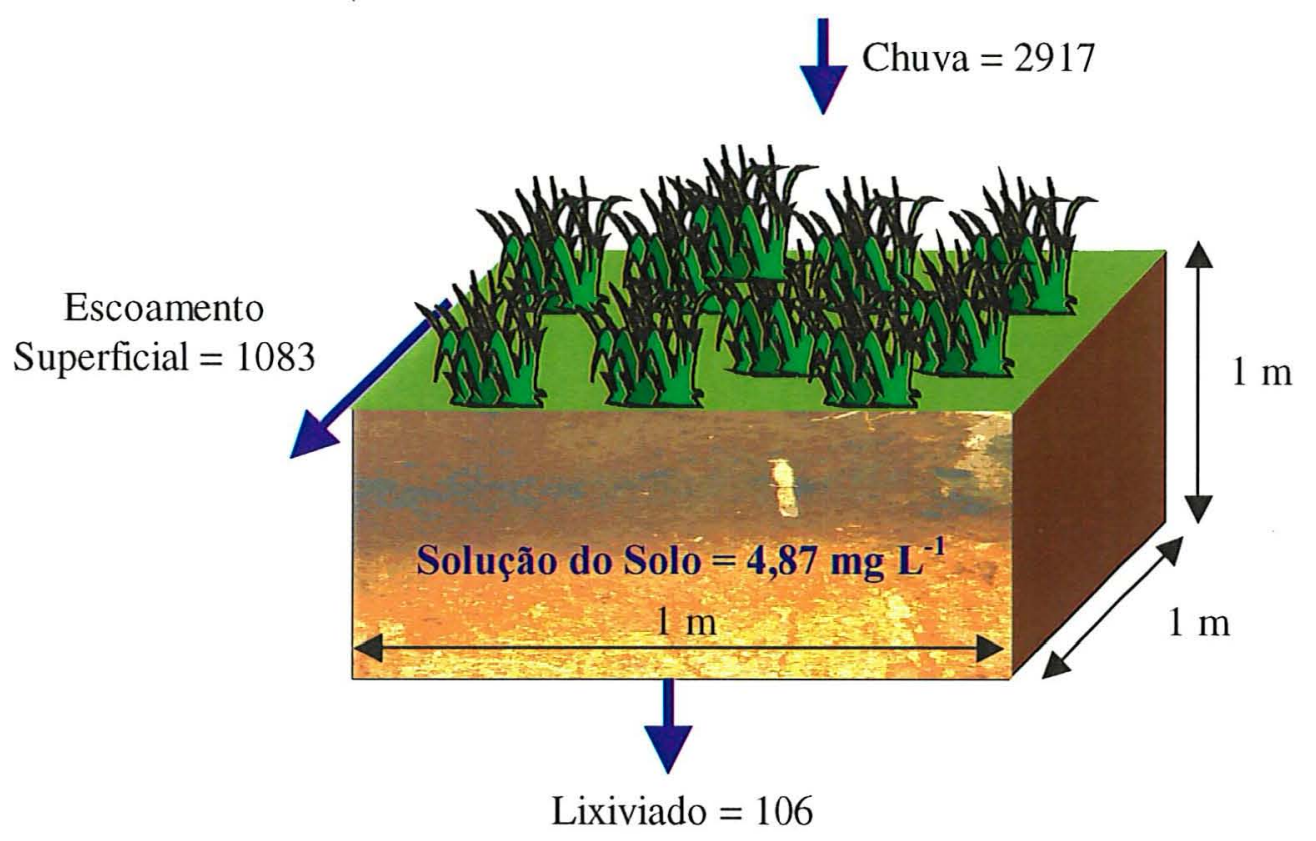

Figurá 20 - Esquema do fluxo de carbono orgânico dissolvido com suas respectivas concentrações $\left(\mathrm{mg}\right.$ de $\mathrm{C} \mathrm{m}^{-2}$ ) na área sob pastagem gradeada.

Comparando a pastagem gradeada com a pastagem controle, nota-se que as perdas na pastagem gradeada por escoamento superficial foram menores, porém as perdas por lixiviação e a concentração de COD na solução do solo foram maiores. As perdas de carbono orgânico dissolvido no sistema de pastagem gradeada foram de $1189 \mathrm{mg} \mathrm{C} \mathrm{m}^{-2}$, sendo o balanço final positivo e da ordem de $1728 \mathrm{mg} \mathrm{C} \mathrm{m}^{-2}$.

É importante relembrar que o balanço final da pastagem controle foi de $1153 \mathrm{mg}$ $\mathrm{C} \mathrm{m} \mathrm{m}^{-2}$. Portanto, conclui-se que a pastagem controle possui uma perda maior de carbono orgânico dissolvido em relação a pastagem controle nesse período estudado. Porém, o principal componente desses resultados ocorridos nesse período, foi o escoamento 
superficial, onde as perdas foram maiores na pastagem controle. Como o período estudado do ano de 2002 foi acompanhado de poucas chuvas, novos estudos são necessários, pois a maior concentração de carbono orgânico dissolvido na solução do solo e as maiores perdas por lixiviação ocorridas no tratamento de pastagem gradeada indicam que se ocorrer maior drenagem de solução no solo, as perdas podem vir a serem maiores nesse tratamento.

A adubação nitrogenada (Bergkvist \& Folkeson, 1992), a competição do COD com $\mathrm{SO}_{4}^{-2}$ (Guggeenber \& Zech, 1992) e a maior taxa de decomposição da matéria orgânica do solo (Brumme \& Beese, 1992), são considerados alguns dos mecanismos atualmente propostos para explicar os aumentos de carbono orgânico dissolvido que são lixiviados pelo solo. As maiores perdas de carbono orgânico dissolvido ocorridas no tratamento de pastagem gradeada, podem ser explicadas em conjunto por esses três mecanismos. A alta quantidade de sulfatos adicionados por fertilizantes (266 kg ha ${ }^{-1}$ ), a aplicação de $42 \mathrm{~kg}$ de $\mathrm{N} \mathrm{ha}^{-1}$, e a possível decomposição mais elevada pela matéria orgânica do solo comprovada através da maior emissão de $\mathrm{CO}_{2}$ (Passianoto et al., 2003 ${ }^{2}$ ), podem ser os responsáveis pela maior quantidade de COD lixiviada nesse tratamento em comparação aos tratamentos de pastagem controle e floresta.

${ }^{1}$ PASSIANOTO, C.C.; AHRENS, T.D.; FEIGL, B.J.; STEUDLER, P.A.; CARMO, J.B.; MELILLO, J.M. Changes in $\mathrm{CO}_{2}, \mathrm{~N}_{2} \mathrm{O}$, and $\mathrm{NO}$ emissions in response to conventional tillage and no-tillage management practices in the State of Rondônia, Brasil, Biological Fertility of Soils, (submetido). 


\section{CONCLUSÕES}

Os fluxos do carbono orgânico dissolvido na solução do solo sob floresta e pastagens tropicais foram avaliados em Rondônia, utilizando-se de lisímetros de tensão, tensão zero e coletores de escoamento superficial, pluviolixiviado e água de chuva em condições de campo. Para atingir esse objetivo instalou-se um experimento em condições de campo, onde os resultados mostraram que:

- O estoque de carbono total do solo na camada de 0-30 $\mathrm{cm}$ no sistema de pastagem com vinte anos de implantação foi $22 \%$ maior $\left(4,56 \mathrm{~kg} \mathrm{C} \mathrm{m}^{-2}\right)$ que a quantidade total de $\mathrm{C}$ existente no solo dessa mesma camada sobre floresta $\left(3,74 \mathrm{~kg} \mathrm{C} \mathrm{m}^{-2}\right)$.

- O sistema florestal possui uma entrada de carbono orgânico dissolvido de $5277 \mathrm{mg} \mathrm{C} \mathrm{m}{ }^{-2}$ devido às grandes concentrações na solução do pluviolixiviado (2255 $\mathrm{mg} \mathrm{C} \mathrm{m}^{-2}$ ) e as pequenas saídas por escoamento superficial (173 $\mathrm{mg} \mathrm{C} \mathrm{m}^{-2}$ ) e por lixiviação (7,34 $\mathrm{mg} \mathrm{C} \mathrm{m}^{-2}$ ).

- A pastagem controle, apresentou as maiores saídas de carbono orgânico dissolvido no solo, $1679 \mathrm{mg} \mathrm{C} \mathrm{m}^{-2}$ por escoamento superficial e $85 \mathrm{mg} \mathrm{C} \mathrm{m}^{-2}$ por lixiviação, tornando a quantidade final de carbono orgânico dissolvido que entra nesse sistema cinco vezes menores que na floresta.

- Na pastagem gradeada as saídas de carbono orgânico dissolvido por escoamento superficial foram $55 \%$ menores que no controle $\left(1679 \mathrm{~kg} \mathrm{~m}^{-2}\right)$. $\mathrm{O}$ tratamento apresentou ainda as maiores perdas por lixiviação ( $106 \mathrm{mg} \mathrm{C} \mathrm{m}^{-2}$ ), aproximadamente $25 \%$ a mais que na pastagem controle $\left(85 \mathrm{mg} \mathrm{m}^{-2}\right)$, possivelmente devido as altas taxas de adubação sulfatadas e ao aumento da decomposição da matéria orgânica, comprovada pela maior emissão de $\mathrm{CO}_{2}$ registrado nesse tratamento. 
- A maior concentração de carbono orgânico na solução do solo foi encontrado no tratamento de pastagem gradeada $\left(4,87 \mathrm{mg} \mathrm{L}^{-1}\right)$, seguido pelo solo sob floresta $\left(4,09 \mathrm{mg} \mathrm{L}^{-1}\right)$ e o solo sob pastagem controle $\left(3,63 \mathrm{mg} \mathrm{L}^{-1}\right)$.

A partir das informações descritas conclui-se que o sistema florestal por se encontrar em equilíbrio dinâmico, apresenta perdas reduzidas de carbono orgânico dissolvido. Ao se alterar o uso da terra e utiliza-la por vinte anos como pastagem nota-se que apesar do estoque de carbono no solo aumentar, como o sistema não se encontra em equilíbrio, a quantidade de carbono orgânico dissolvido que sai do sistema por escoamento superficial e por lixiviação torna-se em média cinco vezes maior que na floresta. Com a aplicação de técnicas como a gradagem e adubação, utilizadas para recuperação dessa pastagem, ocorre diminuição das perdas de carbono orgânico dissolvido por escoamento superficial, podendo ser atribuídas a pastagem mais densa e a maior infiltração superficial. Nota-se porém, que o estoque de carbono do solo diminui, provavelmente devido a baixa estabilidade desse carbono e conseqüentemente ocorre um aumento na concentração do carbono orgânico dissolvido na solução do solo. Um dos efeitos desse aumento foram as maiores perdas de carbono orgânico dissolvido por lixiviação. 
$\because$

ANEXOS 


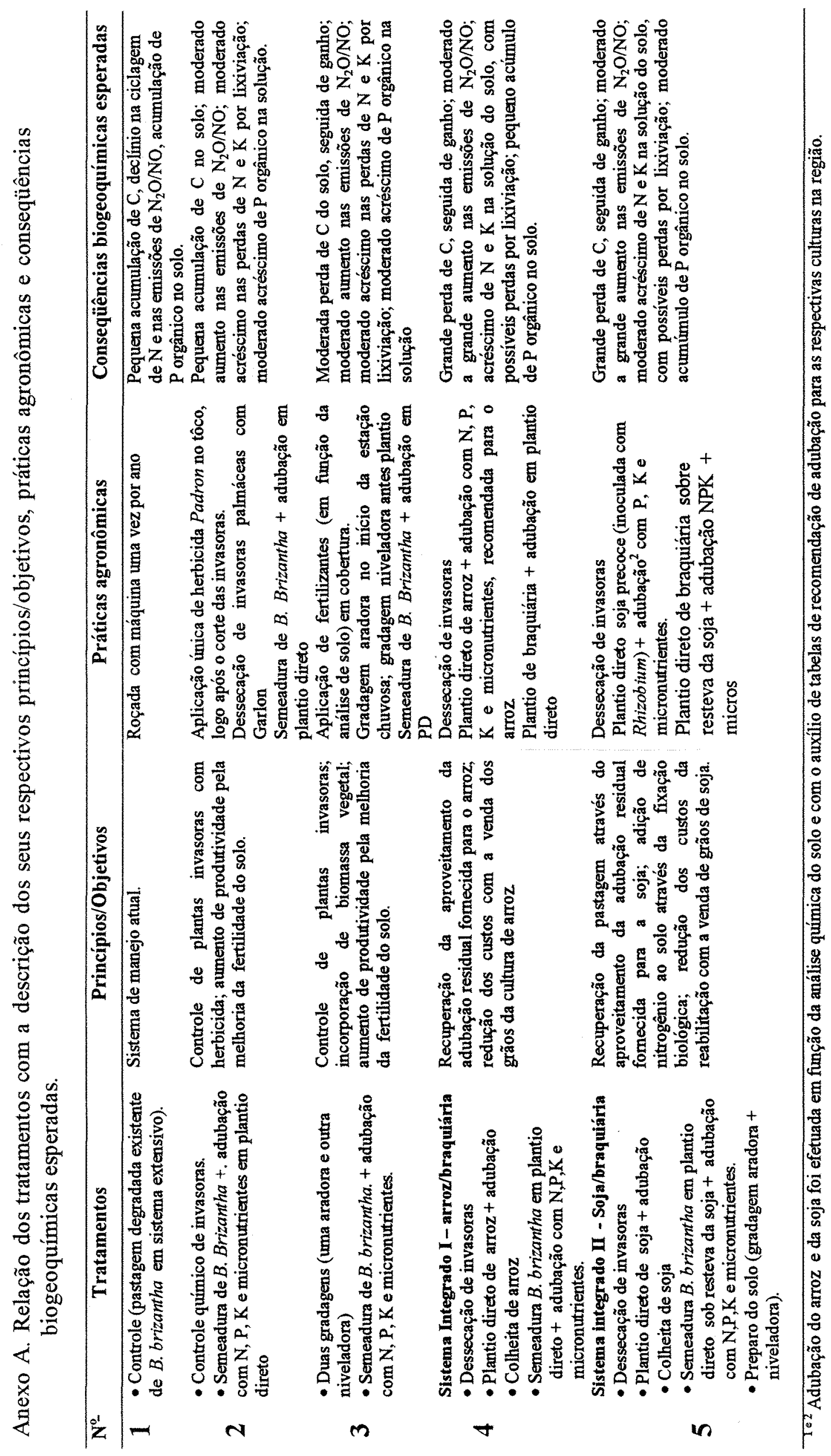




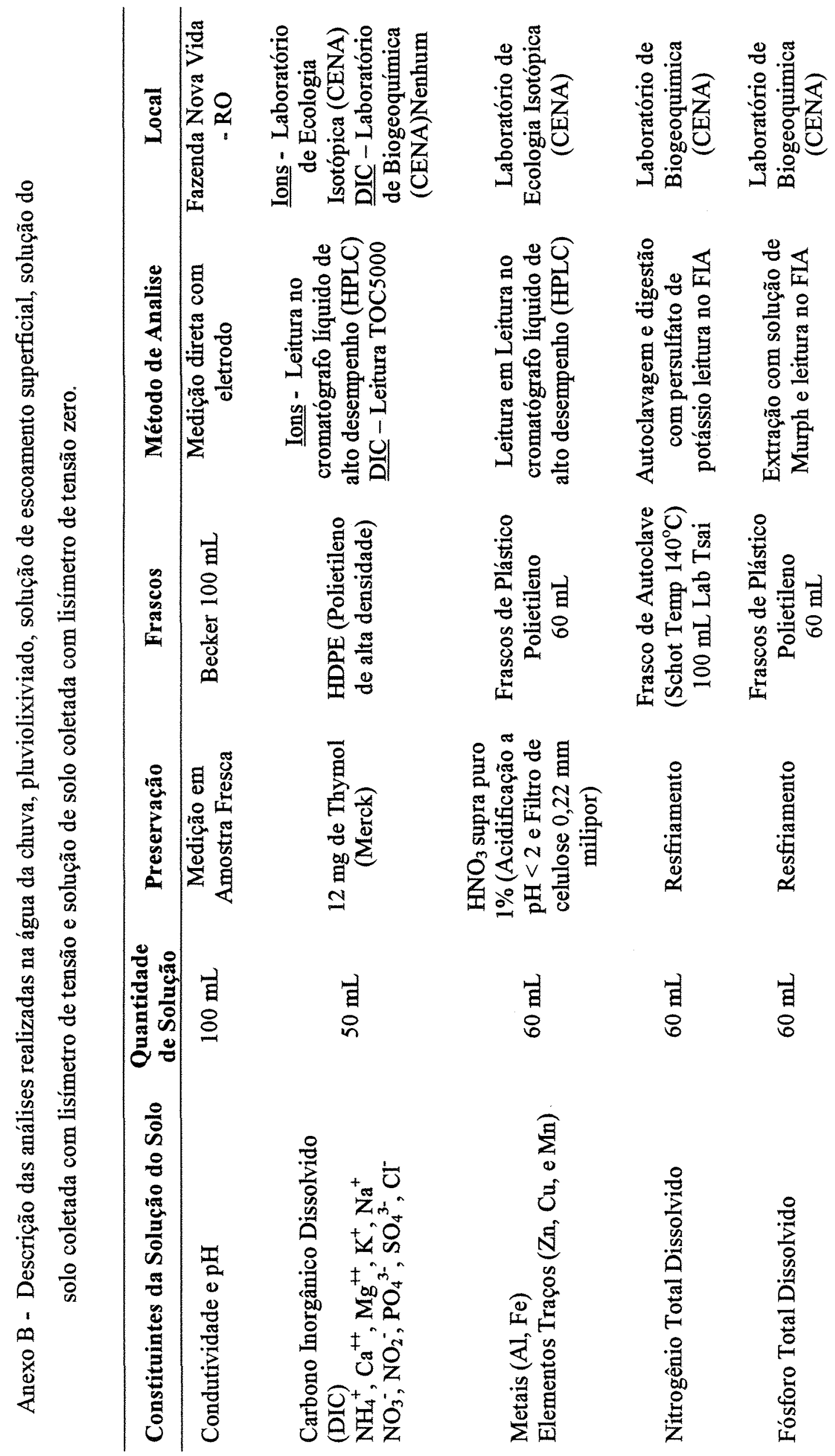




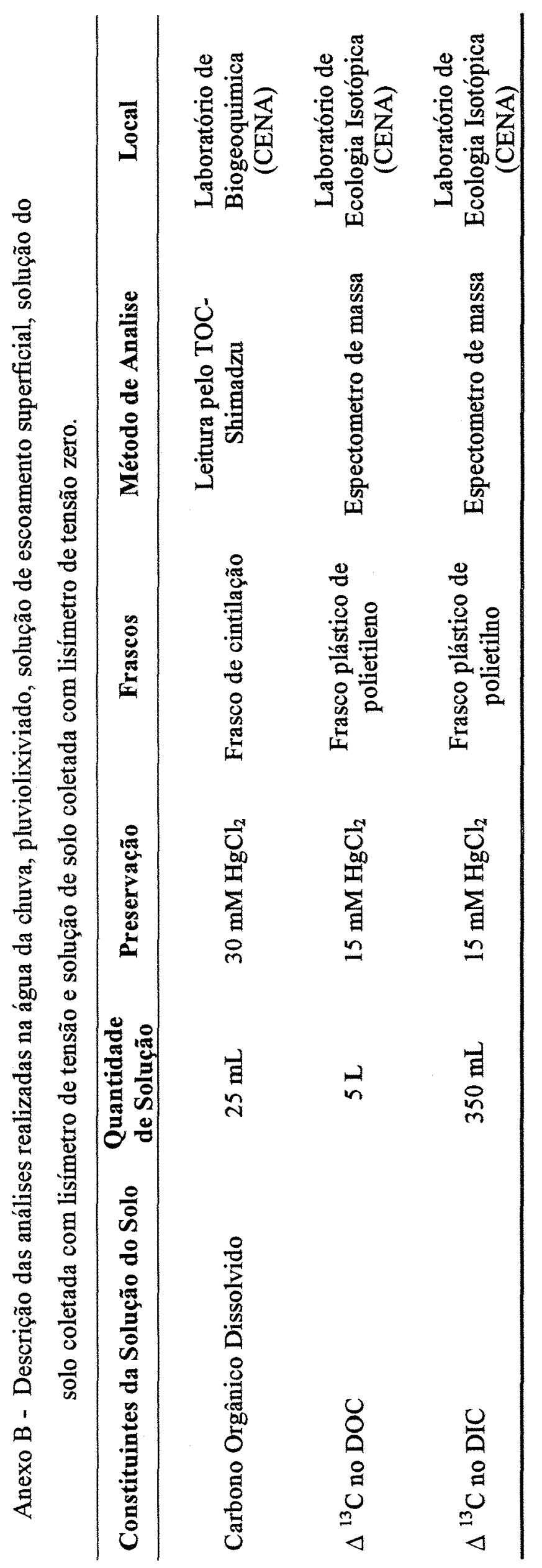




\section{REFERÊNCIAS BIBLIOGRÁFICAS}

ARZHANOVA, V.S.; VERTEL, Y.F. Trace elements and soluble organic matter in lysimeter water. Sovietic Soil Science, v. 13, p. 72-78, 1981.

AUFDENKAMPE, A.K; HEDGES, J.I.; RICHEY, J.E.; KRUSCHE, A.V.; LERENA. C.. Sorptive fractionation of dissolved organic nitrogen and amino acids onto fine sediments within the Amazon Basin. Limnology Oceanographic v. 46, n.8, p. 1921$1935,2001$.

BAHAM, J. Prediction of ion activities in soil solutions Computer equilibrium modeling. Soil Science Society of America Journal, v. 48, p. 525-531, 1984.

BARBEE, G.C.; BROWN, K.W. Comparison between suction and free-drainage soil solution samplers. Soil Science, v. 141, p. 149-154, 1986.

BARROS, E.; GRIMALDI, M.; DESJARDINS, T.; SARRAZIN, M.; CHAUVEL, A.; LAVELLE, $P$. Efeitos de pastagens sobre a macrofauna e o funcionamento hídrico do solo na Amazônia Central. In: FERTBIO 98, Caxambu, 1998. Resumos. Lavras: UFLA; SBCS; SBM, 1998. p.798.

BASTOS, T.X.; DINIZ, T.D. de A.S. Avaliação de clima do Estado de Rondônia para desenvolvimento agrícola. Belém: EMBRAPA/CPATU, 1982. 28p. (Boletim de Pesquisa, 44) 
BERGKVIST, B.; FOLKESON, L. Soil acidification and element fluxes of a Fagus sylvatica forest as influenced by simulated nitrogen deposition. Water Air Soil Pollution, v. 62, p. 111-133, 1992.

BERNER, R. A. The carbonate-silicate geochemical cycle and its effect on atmospheric carbon dioxide over the past 100 million years. American Jornal of Science, v.283, p. 641-683, 1983.

BERNOUX, M.; FEIGL, B.J.; CERRI, C.C.; GERALDES, A.P.A.; FERNANDES, S.A.P.F.; Carbono e nitrogênio em solos de uma cronossequencia de floresta tropical: pastagem de Paragominas. Scientia Agricola. v. 56, p. 777-783, 1999.

BROUWER, L.C. Nutrient cycling in pristine and logged tropical rain forests, a study in guyana. Tropenbos, v.1, p. 23-35, 1996.

BRUMME, R; BEESE, F. Effects of liming and nitrogen fertilization on emissions of $\mathrm{CO}_{2}$ and $\mathrm{N}_{2} \mathrm{O}$ from temperate forest. Journal of Enviroment Quality, v. 24, p. 209-226, 1992.

BUSCHBACHER, R; UHL, C.; SERRÃO, A.S. Abandoned pastures in eastern Amazonia, II. Nutrient stocks in the soil and vegetation. Journal of Ecology, v.76, p.682-699, 1988.

CASSIOLATO,M.E.; MEDA, A.R.; PAVAN, M.A.; MIYAZAWA, M.; OLIVEIRA, J.C. Evaliation of oat extracts on the efficiency of lime in soil. Brazilian Archives of Biology and Technology, v.43, n.5, p. 533-536, 2000.

CERRI, C.C.; ANDREUX, F.G. Changes in organic carbon content in oxisols cultivated with sugar cane and pasture based on ${ }^{13} \mathrm{C}$ natural abundance measurement. In: INTERNATIONAL CONGRESS OF SOIL SCIENCE, 14., Kyoto, 1990. Kyoto: v.4, p.98-103, 1990. 
CERRI, C.C.; FELLER, C.;CHAUVEL, A. Evolução das principais propriedades de um latossolo vermelho escuro após desmatamento e cultivo por doze e cinqüenta anos com cana-de-açucar. ORSTOM Série Pédologie, v. 26, p. 37-50, 1991.

CHAVES, J.C.D.; PAVAN, M.A.; MIYAZAWA, M. Especiação química da solução do solo para interpretação da absorção de cálcio e alumínio por raízes de cafeeiros. Pesquisa Agropecuária Brasileira, v.26, p.447-453, 1991.

COLE, D.W. Soil nutrient supply in natural and managed forests. Plant and Soil, v. 168, n. 169, p. $43-53,1995$.

CRONAN, C.S.; AIKEN, G.R Chemistry and transport of soluble humic substance in forested watershed of Adirondack Park, New York. Geochimica Cosmoshim Acta, v. 49, p. $1697-1705,1985$.

CURRIE, W.S.; ABER, J.D.; McDOWELL, W.H.; BOONER.D.; MAGILL, A.H., Vertical transport of dissolved organic $\mathrm{C}$ and $\mathrm{N}$ under long term $\mathrm{N}$ amendments in pine and hardwood forest. Biogeochemistry, v.35, p. 471-505, 1996.

DAHLGREN, R.A., Comparison of soil solution extraction producers: effect on solute chemistry. Communications in Soil Science and Plant Analysis, v. 24, p. 15-16, $1783-$ $1794,1993$.

DALVA, M.; MOORE, T.R. Sources and sinks of dissolved organic carbon in a forest swamp catchment. Biogeochemistry, v. 15, p.1-19, 1991.

DEVOL, A.H.; HEDGES, J.I. Organic matter and nutrients in the mainstem Amazon River. In: McCLAIN, M.E.; VICTORIA, RL.; RICHEY, J.E. (Ed.), The biogeochemistry of the Amazon Basin. Oxford: Oxford University Press, 2001. p. 275-306. 
DORAN, J.W.; PARKIN, T.B. Defining and assessing soil quality. Soil Science Society of America Journal, v. 35, p. 3-21, 1994.

EMPRESA BRASILEIRA DE PESQUISA AGROPECUÁRIA. Sistema Brasileiro de Classificação de Solos. Rio de Janeiro, 1999. 412p.

EWEL, J.; BERISH, C.; BRONW, B.; PRICE, N.. Slash and burn impacts on a Costa Rica wet forest site. Ecology, v.62, 816-829, 1981.

FISHER, M.J.; RAO, I.M.; AYARZA, M.A.; LASCANO, C.E., SANZ, J.I.; THOMAS, R.J.; VERA, R.R. Carbon Storage by introduced deep-rooted grasses in the South America savannas. Nature, v. 371, n.236-238, 1994.

FEARNSIDE, P.M. Amazon deforestation and global warming: carbon stocks in vegetation replacing Brazil's Amazon forest. Forest Ecology and Management, v.80, p.21-34, 1996.

FEIGL, B.J.; MELILLO, J.; CERRI, C.C. Changes in the origin and quality of soil organic matter after pasture introduction in Rondônia (Brazil). Plant and Soil, n. 175, p.21-29, 1995.

FRANCHINI, J.C.; MALAVOLTA, E.; MIYAZAWA, M.; PAVAN, M.A. Alterações químicas em solos ácidos após a aplicação de resíduos vegetais. Revista Brasileira de Ciência do Solo, v.23, p. 533-542, 1999a.

FRANCHINI, J.C.; MIYAZAWA, M.; PAVAN, M.A.; MALAVOLTA, E. Dinâmica de íons em solo ácido lixiviado com extratos de resíduos de adubos verdes e soluções puras de ácidos orgânicos. Pesquisa Agropecuária Brasileira, v.34, p. 2267-2276, 1999 b. 
GIESLER, R; LUNDSTROM, U.S.; GRIP, H. Comparison of soil solution chemistry assessment using zero-tension lysimeters or centrifugation. European Journal of Soil Science, v. 47, p. 395-405, 1996.

GILLMAN, G.P.; BELL, L.C. Soil Solution studies on weathered soil from tropical North Queensland. Australian Journal Soil Research, v. 16, p. 67-77, 1978.

GROSSMANN, J.; UDLUFT, P. The extraction of soil water by the suction-cup method: a review. Journal of Soil Science, v. 42, p. 83-93, 1991.

GUGGERBERGER, G.; ZECH, W. Retention of dissolved organic carbonand sulfate in aggregated acid forest soils. Journal of Environment Quality, v. 21, p. 643-653, 1992.

HEDGES, J.I; ERTEL, J.R.; QUAY, P.D.; GROOTES, P.M.; RICHEY, J.E.; DEVOL, A.H.; FARWELL, G.W.; SCHMITT, F.W.; SALATI, E. Organic carbon-14 in the Amazon River system. Science, v. 231, p. 1129-1131, 1986.

HEDGES, J.I.; MAYORGA, E.; TSAMAKIS, E.; MCCLAIN, M.E; AUFDENKAMPE, A.; QUAY, P.D; RICHEY, J.E.; BENNER, R.; OPSAHL, S.; BLACK, B.; PIMENTAL, T.; QUINTANILLA, J.; MAURICE, L. Organic matter in Bolivian tributaries of the Amazon River: a comparison to the lower mainstem. Limnology Oceanographic, v. 45, n.7, p. 1449-66, 2000.

HENDERSHOT, W.H; COURCHESNE, F. Comparison of soil solution chemistry in zerotension and ceramic cup tension lysimeters. Journal of Soil Science, v.42, p. 577-583, 1991.

HOUGHTON, R.A. The global effectsof tropical deforestation. Environment Science and Technology, v. 24, p. 414-422, 1990. 
HOUGHTON, R.A.; SKOLE, D.L.; NOBRE, C.A.; HACKLER, J.L.; LAWRENCE, K.T.; CHOMENTOWSKI, W.H. Annual fluxes of carbon from deflorestation and regrowth in the Brazilian Amazon. Nature, v. 403, p. 301-304. 2000.

HOPE, D.; PALMER, S.M.; BLLLETT, M.F.; DAWSON, J.J.C. Carbon dioxide and methane evasion from a temperate peatland stream. Limnology Oceanographic, v. 46 n. 4, p. $847-57,2001$.

HYNDMAN, R.D.; DALLIMORE, S.R. Natural gas hydrate studies in Canadá. Canadian Society of Exploration Geophysicists. The Recorder, v. 26, p. 11-20, 2001.

INSTITUTO NACIONAL DE PESQUISAS ESPACIAIS. Amazônia: desflorestamento 1995-1997. São José dos Campos, 1998.

INSTITUTO NACIONAL DE PESQUISAS ESPACIAIS. Monitoramento da Floresta Amazônica Brasileira por Satélite: 1995-2001. http://www.inpe.Br/ informacões_Eventos/amazônia.htm, 2001. (13 dez. 2002).

JOFFE, J.S. Lysimeter studies: I - Moisture percolation through the soil profile. Soil Science, v. 34, p. 123-142, 1932.

JORDAN, C.F. The nutrient balance of an Amazonian rain forest. Ecology, v. 63, p. 647-654, 1982.

LARSON, W.E; PIRCE, F.J. The dynamics of soil quality as measure of sustainable management. In: DORAM, J.W. (Eds). Defining soil quality for sustainable enviroment. Madison: American Society of Agronomy, 1994. p. 37-51.

LAL, R; PIRCE, F.J. The vanish resource. In: LAL, R; PIRCE, F.J. (Ed). Soil management for sustainability. Soil and Water Conservation Society, 1991. p. 1-5. 
LUIZÃO, F.J. Litter production and mineral element input to the forest floor in a central Amazonian forest. GeoJournal, v.19, p. 407-417, 1989.

MAGGS, J.; HEWETT, B. Organic carbon and nutrients in surface soils from some primary rain forest derived grassland and secondary rainforest on the Atherton Taberland in Noth East Queensland. Australian Journal Soil Reserch, v. 31, p. 343-351, 1993.

MAHENDRAPPA, M.K. Abilites of organic horizons under some eastern Canadian forest stands to alter the acidity of rainwater. Canadian Journal Forest Reserch, v. 16, p. $18-22,1986$.

MAHENDRAPPA, M.K; SALONIUS. P.O. nutrient dynamics and growth response in a fertilized black spruce stand. Soil Science Society of America Journal, v. 46, p. 127-133, 1982.

MALHI, Y; GRACE, J. Tropical forests and atmospheric carbon dioxide. Trends Ecology and Evolution, v. 15, n. 8, p. 332-337, 2000.

MARTINS, P.F.S.; CERRI, C.C., VOLKOFF, B.; ANDREUX, F.; CHAUVEL, A.. Consequence of clearing and tillage on the soil of a natural Amazonia Ecosystem. Forest Ecology and Management, v. 38, p. 173-182, 1991.

MARTINS, O.C., Causas da degradação de pastagens e rentabilidade econômica corretamente adubadas. In: CONGRESSO BRASILEIRO DA RAÇAS ZEBUINAS, 2., Uberaba, 1996, Anais Uberaba: 1996.

McCLAIN, M.E.; RICHEY, J.E.; BRANDES, J.A.; PIMENTEL, T.P.. Dissolved organic matter and terrestrial-lotic linkages in the central Amazon Basin, Brazil. Global Biogeochemical Cycles, v. 11, n. 3, p. 295-311, 1997. 
McDOWELL, W.H.; WOOD, T. Podzolidation: Soil processes control dissolved organic carbon concentration in stream water. Soil Science, v. 137, p. 23-32, 1984.

MEDA, A.R.; CASSIOLATO, M.E.; PAVAN, M.A.; MIYAZAWA, M. Alleviating soil acicity through plant organic compounds. Brazilian Archives of Biology and Technology, v.43, n.5, p. 533-536, 2000.

MEIWES, K.J.; MERINO, A., BEESE, F.O. Chemical composition of throughfall, soil water, leaves and leaf litter in beech Forest receiving long term application of ammonium sulphate. Plant and Soil, v. 201, p. 217-230, 1998.

MIYAZAWA, M.; CHIARICE, G.D.; PAVAN, M.A. Amenização da toxidade de alumínio às raizes do trigo pela complexação com ácidos orgânicos. Revista Brasileira de Ciência do Solo, v. 16, p. 209-215, 1992.

MORAES, J.F.L. Movimento de nutrientes em latossolo vermelho escuro. Pesquisa Agropecuária Brasileira, v. 26, p. 85-97, 1991.

MORAES, J.F.L. Propriedades do solo e dinâmica da matéria orgânica associada às mudanças do uso da terra em Rondônia (RO)/Brasil. Piracicaba, 1995. 69p. Tese (Doutorado) Escola Superior de Agricultura 'Luiz de Queiroz', Universidade de São Paulo.

MORAES, J.F.L.; CERRI, C.C.; MELILO, J.M.; KICKLIGHTER, D.; NELLL, C.; SKOLE, D.L.; STEUDLER, P.A. Soil carbon stocks of the brazilian amazon basin. Soil Science Society of America Journal, v.59, p.244-247, 1995.

MORAES, J.F.L.; VOLKOFF, B.; CERRI, C.C.; BERNOUX, M. Soil properties under Amazon forest changes due to pasture installation in Rondônia, Brasil. Geoderma, v.70, p.63-81, 1996. 
MOREIRA, L.; ASSAD, E.D. Segmentação e classificação supervisionada para identificar pastagens degradadas, http://www.tecgraf.puc-rio.br/geoinfo2000/ anais/ 008.pdf. (13 dez. 2002).

NETTLETON, W.D.; MacCRACKEN, RJ. Organic Compounds in soil water of some Ultissols of the Atlantic Coastal Plain. Journal of Environmental Quality, v.1, p. 387$389,1972$.

NOBRE, C.A. Amazônia e o carbono atmosférico. Scientific American Brazil, v. 6, p. 26-31 2002.

NOVIDIN, S.C.; DRISCOLL, C.T.; LIKENS, G.E. Simple partitioning of aniona and dissolved organic carbon in a forest soil. Soil Science, v. 142, p. 27-35, 1986.

PAVAN, M.A. Movimentação do calcário no solo através de técnicas de manejo da cobertura vegetal em pomares de macieira. Revista Brasileira de Fruticultura, v.16, p. 131-139, 1985.

PICCOLO, M.C.; ANDREUX, F.; CERRI, C.C. Hidrochemistry of soil solution collected with tension-free lysimeters in native and cut-and-burned tropical rain forest in central amazônia. Geochimica Brasileira, v.8, n. 1, p.51-63, 1994.

PHILlIPS, O. L.; MALHI, Y.; HIGUCHI, N.; LAURANCE, W. F.; NUNEZ, P. V.; VASQUEZ, R. M.; LAURANCE, S. G.; FERREIRA, L. V.; STREN, M.; BROWN, S.; GRACE, J. Changes in the carbon balance of tropical forests : Evidence from long-term plots. Science, v. 282, n. 5388, p. 439-442, 1998.

QUALLS, R.G.; HAINES, B.L. Geochemistry of dissolved organic nutrients in water percolating through a forest ecosystem. Soil Science Society of America Journal. v. 55, p.1112-1123, 1991. 
RASMUSSEN, R.A.; KHALIL, M.A.K. Atmospheric trace gases: trends and distributions over the last decade. Science, v. 232, p. 1623-1624, 1986.

RICHEY, J.E.; MELACK, J.M.; AUFDENKAMPE, A.K.; BALLESTER, V.M.; HESS, L. Outgassing from Amazonian rivers and wetlands as a large tropical souce of atmospheric $\mathrm{CO}_{2}$. Nature, v. 416, p. 617-620. 2002.

RICHEY, J.E.; HEDGES, J.I.; DEVOL, A.H.; QUAY, P.D.; VICTORIA, R; MARTINELLI, L.; FORSBERG. B.R.. Biogeochemistry of carbon in the Amazon river. Limnology Oceanographic, v. 35, n.2, p. 352-371, 1990.

ROOSE, E.J.; TUREAUX, P.H. des. Deux méthodes de mesure du drainage vertical dans un sol en place. L'Agronomie, v.25, n.12, p. 1079-1087, 1970.

SALETI, E.; MARQUES, J.; Climatology and hidrology of Amazonia. In: PRANCE, G.T.; LOVEJOY, T.M. (Ed) Amazonia. Oxford: Pergamon Press, 1986. p. 267-276.

SANCHEZ, P.A.; VILLACHICA, J.H.; BANDY, D.E. Soil fertility dynamics after clearing a tropical rainforest in Peru. Soil Science Society of America Journal, v.47, p.1171-1178, 1983.

SANTOS, A.; RIBEIRO, N.M. Nitrogênio na água do solo de ecossistema de Campina Amazônica. Acta Amazônica, v.5, p. 173-185, 1975.

SCERNE, R.M.C.; SANTOS, A.O. da S.; SANTOS, M.M.; NETO, A.F. Aspectos agroclimáticos do município de Ouro Preto d'Oeste-RO: atualização qüinqüenal. Belém: CEPLAC; SUPOR, 2000. 48p. (Boletim Técnico 17).

SCHINDLER, D.W.; BAYLEY, S.E.; CURTIS, P.J.; PARKER, B.R.; STAINTON, M.P.; KELLY, C.A. Natural and man-caused factor affecting the abundance and cycling of dissolved organic substances in precambrian shield lakes. Hidrobiologia, v. 229, p. 1-21, 1992. 
SKOLE, D.S.; CHOMENTOWSKI, W, H.; SALAS, W.A.; NOBRE, A.D. Physical and human dimensions of deforestation in Amazonia. BioScience, v.44, p.314-328, 1994.

SMETHURST. P.J. Soil solution and other soil analyses as indicators of nutrient supply: a review. Forest Ecology and Management. v. 138, p. 397-411, 2000.

STALLARD, R.F. Terrestrial sedimentation and the carbon cycle: Coupling weathering and erosion to carbon burial. Global Biogeochemical Cyles, v. 12, n. 2, p. 231-257, 1998.

STARK, N.; JORDAN, C.F. Nutrient retention in the root mat of an Amazonian rain. Forest Ecology, v. 59, p. 404-432, 1978.

SteUdLER, P.A; GARCIA-MONTIEL, D.C.; PICCOLO C.M.; NEILL, C.; MELILLO, J.M.; FEIGL, B.J.; CERRI, C.C. Trace gas responses of tropical forest and pasture soils to $\mathrm{N}$ and P fertilization. Global Biogeochemical Cycles, v. 16, n. 2, 2002.

STUMM, W.; MORGAN, J. J.. Aquatic chemistry: chemical equilibria and rates in natural waters. New York: Wiley Interscience, 1996.

SOGN, T.A.; ABRAHAMSEM, G.; STUANES, A.O. Lysimeter study with a cambic arenosol exposed to artificial acid rain. II - Input-output budgets and soil chemical properties. Water, Air and Soil Pollution, v.68, p. 505-524, 1993.

TIAN, H.; MELILLO, J.M.; KICKLIGHTER, D.W.; McGUIRE, A.D.; HELFRICH III, J.V.K; MOORE III, B.; VÖRÖSMARTY, C.J. Effect of interannual climate variability on carbon storage in Amazonian ecosystems. Nature, v. 396, p. 664-667. 1998.

UHL, C.; JORDAN, C. Sucession and nutrient dynamics following forest cutting and burning in Amazônia. Ecology, v.65, p. 1476-1490, 1984. 
UHL, C.; CLARK, K.; DEZZEO, N.; MARQUIRINO, P. Vegetation dynamics in Amazonian treefall gaps. Ecology, v. 69, p.751-763, 1988.

UHLENHOPP, A.G.; HOBBIE, J.E.; VALLINO, J.J., Effects of land use on the degradability of dissolved organic matter in three water sheds of the plum island sound estuary. Biological Bulletin, v. 189, p. 256-257, 1995.

VELASCO, F.P.; LOZANO, J.M. Cambios sinecológicos de la microflora telurica associados a las repolaciones florestales com especies exoticas. Anales de Edafologia y Agrobiologia, v.37, p.871 - 878, 1979.

VELDKAMP, E. Organic carbon turnover in three tropical soil under pasture after deforestation. Soil Science Society of America Journal, v. 58, p. 175-180, 1994.

WESTON, C.J.; ATTIWILL, P.M. Effects of fire and harvesting on nitrogen transformations and ionic mobility in soils of Eucalyptus regnans forests of south-eastern Australia. Oecology, v.83, p.20-26, 1990.

WOLT, J. Soil solution chemistry: applications to environmental science and agriculture. New York: Jonh Wiley \& Sons, Inc. 1994. 345 p.

YAVTTT, J.B.; FAHEY, T.J. An experimental analysis solution chemistry in a lodge-pole pine forest floor. Oikos, v. 433, p. 222-234, 1984. 